UC-NRLF

Iinifing

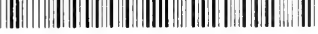

\$B 273 593 


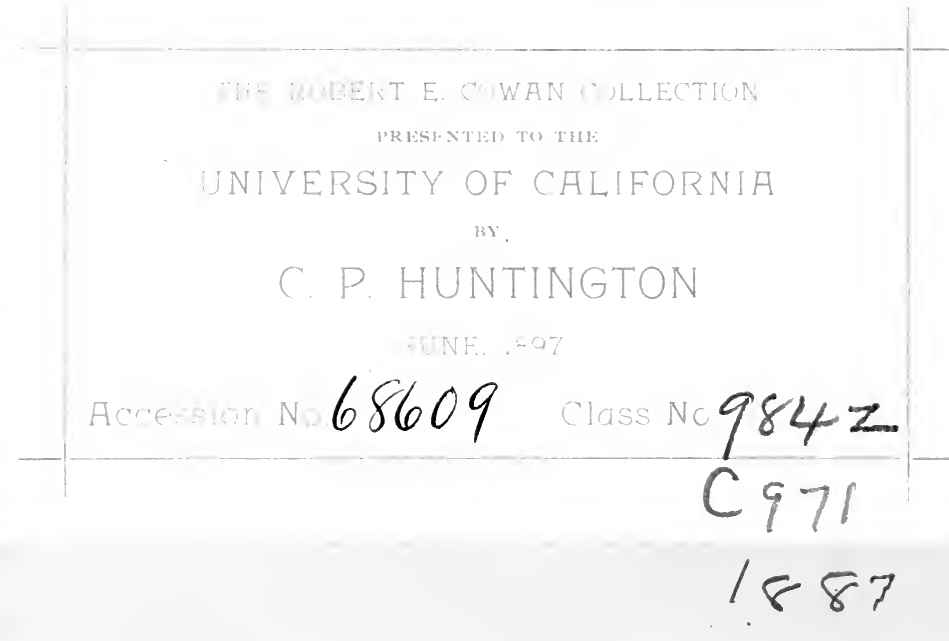




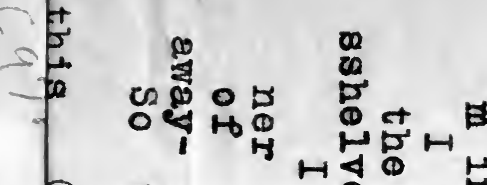

2.

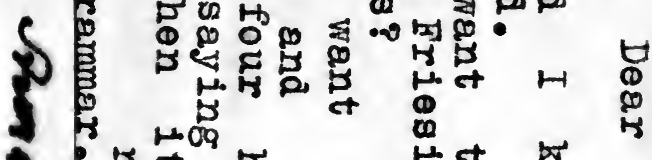

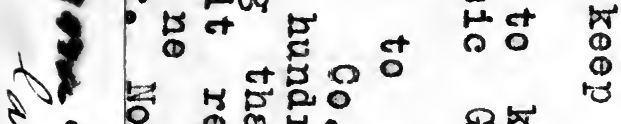

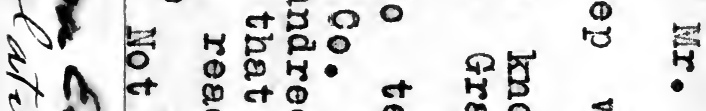

సौ

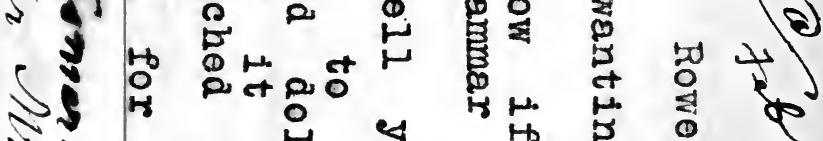

సं

J\&. 09 व

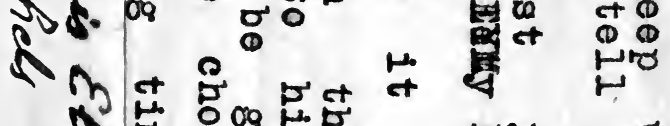

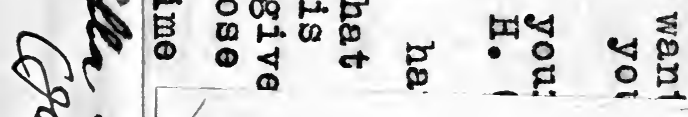




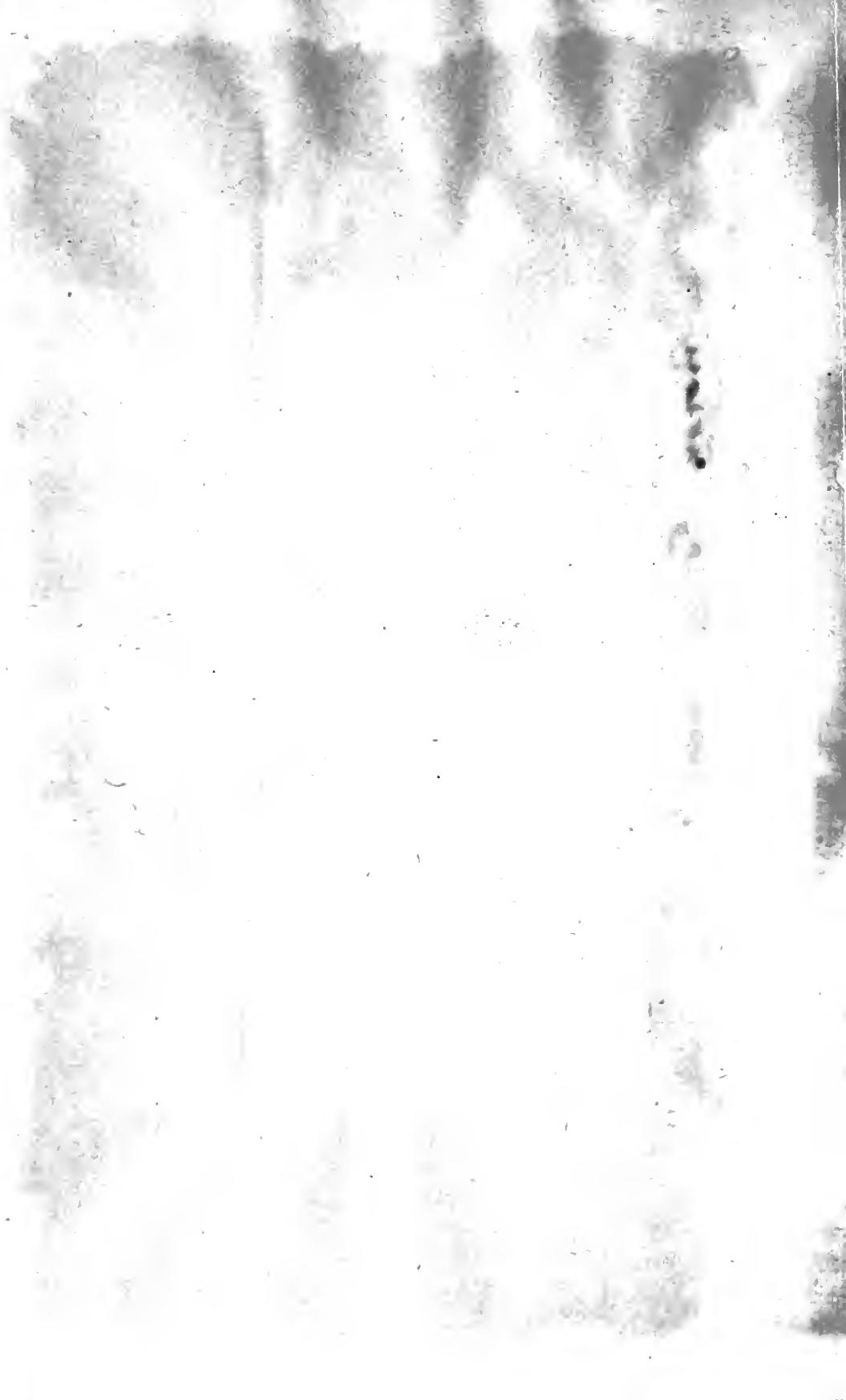


A GRAMMAR

OF THE

OLD FRIESIC LANGUAGE. 



\section{A GRAMMAR}

OF THE

\section{OLID FRIESIC LANGUAGE.}

BY

ADLEY H. CUMMINS, A.M.

"Felix ea gens præ reliquis Germaniæ populis, quod antiquas scites non solum felici Marte tuita est, sed et fines ferro longe lateque protulit, et vetus ac nobile nomen in hodiernum diem retinuit."

-Heinfccir Antio. Germ., L. i. c. 2, sec. 29.

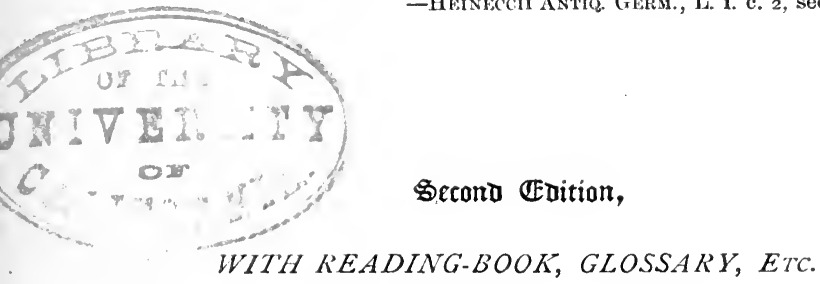

WITH READING-BOOK, GLOSSARY, ETC.

LONUON :

TRÜBNER \& C O., L U D GATE H I L.

1887.

[All rights reserved.] 


\section{9}

25athantone press

BATIANTYNE, HANSON AND CO.

HUINGIRGIH AND I.ONDUN 


$$
\text { 'To }
$$

HYDE CLARKE, D.C.L., F.S.S.,

$$
\text { AS A }
$$

TRIBUTE OF RESPECT AND ESTEEM. 
Digitized by the Internet Archive in 2007 with funding from

Microsoft Corporation 


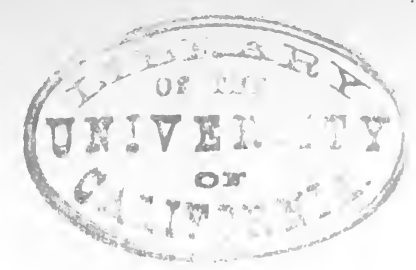

\section{INTRODUCTION.}

IN the year I 3 B.c. Drusus, the Roman general, afterwards surnamed Germanicus, found a tribe of Germans called by themselves Fresar, and by the Romans Frisii, dwelling on the north-west coast of Germany, between the mouth of the Rhine and of the Ems, together with the Batavi, Bracteri, and Chauci, and not far removed from their more northern brethren, the Angles, Jutes, and Saxons.

We find references made to them by Pliny, Tacitus, and Ptolemy, all placing them virtually in the same position. They came into collision with Drusus and experienced a terrible defeat, but in 28 A.D. retaliated upon the Romans, by rising in rebellion against them. They were, however, soon again brought into subjection, and yet shortly thereafter began to expand their borders, absorbing the Chauci, occupying the lands to the southward as fast as vacated by the Franks, and spreading along the shore of the German Ocean to Jutland, where they were known as Strand Frisians. We soon lose sight of them as connected with the Roman Empire, and in the fifth and sixth centuries the Germanic flood swept away all traces of the Imperial dominion over them.

The Frisians did not as a body accompany the other members of the common Gothic stock to Great Britain, but there are scattering evidences to show that many adventurers of that tribe did find a home in those western islands, and copious references are made to their achievements in the ancient naval annals of the islands, as well as in those of the North of Europe in general, but especially in the charming Nederlandsche Legenden of Van Lennep, one of the most gifted poets of Holland. 
It is said in old Dutch of the redoubtable Hengist himself :-

"Een hiet Engistus, een Vriese, een Sas, Die ute Land verdreven was."

"There was Hengist, a Frisian or a Saxon, Who was driven from his land."

Hengist and Horsa are both Frisian names, whether their possessors were myths or not.

Mr. Halbertsma, that indefatigable explorer of Frisian antiquities, has said that the inhabitants of the east of England, where its Germanic invaders landed, and especially of Kent, Sussex, and Hampshire, vividly recalled to him the Frisians in speech and general characteristics. There are various spots in England where there are traces of the Frisians of ancient and modern times; for example, Halifax, to which many excellent weavers, with whom Friesland formerly abounded, migrated ; in whose homely verse is the following saying-

"Gooid braide, botter, and sheese Is gooid Halifax and gooid Friese."

England must have presented many attractions to the ancient members of the Low German stock, if it be true, as stated in Procopius, iv. 20, that "their souls departed through Helder (Hel, hell, Dôr, door-porta inferorum) to England, the nebulous abode of disembodied spirits." The same historian, De bello Gothico, lib. iv. c. I9, names the Frisians as one of the nations that settled Britain :

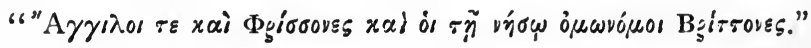

In the seventh and eighth centuries the Frisian dominions were the most extensive, and during those centuries they came in contact with the Frankish power. In 692 Radbod, their chief, was defeated by Pepin de Héristal. These were the Frisii Majores, or West Frisians, and they were compelled to embrace Christianity. Poppo, the chief of the East Frisians, was defeated in $75^{\circ}$ by Charles Martel, who sent to them as apostles St. Boniface and Willibrod. The latter 
became the Bishop of Utrecht, the former of Mayence, then upon the death of Willibrod, Bishop of Utrecht.

In 785 they were finally subdued by Charlemagne, who gave to them a code of laws, in Latin termed the Lex Frisonum. In connection with their laws it may be stated that the feudal system was never erected in Friesland.

For some time after 785 the country was under the control of the Franks, and in 843 Frisia was divided into three parts, Lewis the German receiving East and Central Frisia, and Charles the Bald the West.

Shortly after its subjection by the Franks, Frisia was overrun by the Normans, until A.D. I024. After their departure the country was parcelled out among several petty princes and powers, and has so remained until modern times; but among this people there has always existed that intense love of liberty which has caused its attribute or epithet of "Free" to be its greatest glory, so that after all these centuries the alliteration Free Frisians inevitably presents itself to the mind of the scholar who thinks of the race; and not the least of its glories is the fact that under the leadership of that majestic figure, William the Silent, wherever a blow was struck for hearth or home against the overshadowing despotisms of the south, there in the forefront of the battle were to be found these "wild beggars of the sea," as they were termed by the malignity of their foes.

Old Friesic literature consists almost exclusively of law books, each district having its own. There are a few other fragments found among the laws-the Creation of Man, the ten commandments, a legal riddle, the awful signs and wonders that shall usher in the day of judgment, a sort of scriptural genealogy, and lists of the Roman emperors, and of the bishops who ruled Frisia in early days.

They have been printed in full by Richthofen and Hettema in various works. Their laws extend from the twelfth century to a date late in the fifteenth, and consist of the following:- the laws of the Rüstringer, those of the Brocmen, the Emsiger Recht, the laws of Fivelgo, Hunsingo, Humsterland, West Lauwers, Ostergo, Westergo, Sevenwold, Drenthe, and North Friesland. 
These laws possess the same peculiarities as those common to the other ancient Germans. Crimes were punished by fines and mulcts, and the guilt of the accused ascertained by the ordeal, while innocence was vindicated by the oaths of compurgators and by the other devices of a rude age.

There is also an ecclesiastical code, with numerous provisions for fasts, regarding priests, other spiritual authorities, and the sanctity of churches.

The language is one of the Low German family, very similar to Anglo-Saxon. It is indeed stated that the missionaries sent to the Frisians-who were Anglo-Saxons-immediately upon their arrival in those regions commenced active labour among the people, preaching and exhorting, and experiencing no difficulty in making themselves understood by their hearers,- - such was the close agreement of their respective forms of speech. It is peculiar in this, that up to comparatively modern times, it retained its archaic purity, so that while other members of the common stock were undergoing a change into their middle and modern aspects, it was still spoken in uncorrupted form in its primitive home. 'Thus about the time of Chaucer might perhaps be placed its most flourishing period.

Frisia proper, according to Halbertsma, is a district surrounded by the Zuyder Zee on the north-west and south, almost forming a peninsula. Here was the original seat of the Frisians, and here is their modern home. Friesland is divided at present into the provinces of East and West Friesland, embraced respectively in Hanover and Holland. The Country Friesic, North Friesic, Saterlandic, Schiermonnikoogian, and Hindelopian have remained until these times as spoken dialects. The language is spoken, too, on the islands of Föhr, Sylt, Amrum, Wangerog, and Heligoland.

"The Frisian which is spoken on a small area on the northwestern coast of Germany, between the Scheldt and Jutland, and on the islands near the shore, which has been spoken there for at least two thousand years, and which possesses literary documents as old as the twelfth century, is broken up into endless local dialects. I quote from Kohl's 'Travels:' 
' The commonest things,' he writes, ' which are named almost alike all over Europe receive quite different names in the different Frisian islands. Thus in Amrum father is called aatj; on the Halligs, baba or babe; in Sylt, foder or vaar; in many districts on the mainland, täte; in the eastern part of Föhr, oti or ohitj. Although these people live within a couple of German miles from each other, these words differ more than the Italian padre and the English father. Even the names of their districts and islands are totally different in different dialects. The island of Sylt is called Söl, Sol, and Sal.' Each of these dialects, though it might be made out by a Frisian scholar, is unintelligible except to the peasants of each narrow district in which it prevails.

"What is therefore generally called the Frisian language, and described as such in Frisian grammars, is in reality but one out of many dialects, though, no doubt, the most important."*

A volume of poems in Country Friesic was published by Gysbert Japicx about 1650, denominated Friesche Rymlerye, and one or two minor works and a few unimportant specimens of the modern dialects have from time to time been printed, especially in grammars and handbooks of the various dialects, to illustrate the folk-speech.

The body of laws which has come down to us from the classical period of the speech is naturally looked upon as a monument of inestimable worth. This brings us to regard a matter which cannot be passed over without a brief remark. It might easily be conjectured that the discovery of any more old Friesic texts would be warmly and eagerly welcomed by philologists and others. In 1872 a work entitled Thet Oera Linda Bôk, purporting to be written in more ancient Friesic than any theretofore known, was published in Holland, for another person, by Dr. Ottema-a work which has deceived some of the most eminent Frisian scholars. Its contents can hardly be summed up in brief, for they set history, chronology, mythology, and almost conjecture itself at defiance. It professes to give the history of the race for 3000 or 4000 years, * Max Müller, Lectures on the Science of Language, ist Series, p. 59. 
laying down a system of theology, laws, \&c., and may well in every sense be termed a "Wonderboek" by the learned doctors of Holland.

It is, upon thorough examination, found to be a hodgepodge, a mengelmoes of ancient Friesic, modern Friesic, and modern Dutch, and it is not free from great errors in grammar-just such mistakes, in fact, as its alleged author was wont to make in writing his mother-tongue. From all the facts adduced by its critics there is no reason to doubt that they have conclusively demonstrated it to be the work of Cornelis Over de Linden (who died a few years ago), Superintendent of the Royal Dockyard at the Helder, in the Netherlands, who undertook and performed the prodigious taskthe work of many years - of writing in uncials, in a dead and obsolete language, a lengthy volume for the glorification of his own family and of his presumptive race. Thus did this singular man - to use an inelegant phrase in vogue in Holland - "take the learned world by the nose and lead it around the yard."

It has been deemed advisable to add to this second edition a short Reading Book with glossary, and examples of the Modern Friesic dialects, as well as a few extracts from the Oera Linda Bôk, which, with the extensive additions and improvements, especially in the attempt to illuminate the ancient speech by means of the modern dialects, it is hoped will confer greatly increased usefulness upon this manual.

It would not be within the bounds of reason to hope that the Grammar should be found entirely free from errors or inaccuracies, prepared, as it has been, amidst the distracting activities of the life of a practising attorney, far from associations congenial to such labour, or adapted to render assistance in such a task.

San Francisco, California, Jánuary 1887. 


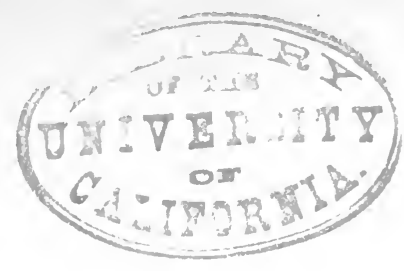

\section{GRAMMATICAL HELPS, LEXICONS, TEXTS, AND WORKS OF REFERENCE.}

Bendsen, B. - Die Nordfriesisclie Sprache nach der Moringer Mundart. 8vo. Leiden, I86o.

Bosworth, J.-The Elements of Anglo-Saxon Grammar. 8vo. London, 1823 .

Bosworth, J.-Anglo-Saxon Dictionary. Royal 8vo. London, 1838.

Bouterwek, $K$. A.-Die vier Evangelien in Alt-Nordhumbrischer Sprache, Gütersloh. 8vo. 1857 .

Braune, W.-Gotische Grammatik. 8vo. Halle, 1880.

Cleasby and Vigfusson.-Icelandic-English Dictionary. 4to. Oxford, 1874 .

Diefenbach, L.-Vergleichendes Wörterbuch der Gothischen Sprache. 2 vols. 8vo. Frankfurt-a-M., I85I.

Doornkaat-Koolman, J. Ten. - Wörterbuch der Ostfriesischen Sprache. 3 vols. 8vo. (1879-84). Norden.

Ehrentraut.-Friesisches Archiv. 2 vols., 8vo. Oldenburg, 1849-54. Epkema, E.-Thet Freske Riim. 4to. Workum, 1835.

Epkema, E.-Woordenboek op de Gedichten en verdere Geschriften van Gijsbert Japicx. 4to. Leeuwaarden, 1824.

Graff, E. G.-Althochđeutscher Sprachschatz. 7 vols. 4to. Berlin, $1834-46$.

Grein, C. W. M.-Sprachschatz der Angelsächsischen Dichter. 2 vols. 8vo. Cassel und Göttingen, I864. 
Grimm, J.-Deutsche Grammatik. 4 vols. 8vo. Göttingen und Berlin, 1831-78.

Grimm, J.-Geschichte der Deutschen Sprache. 2 vols. 8vo. Leipzig, 1880.

Günther, C.-Die Verba im Altostfriesischen. 8vo. Leipzig, I880.

Hahn, K. A.-Mittelhochdeutsche Grammatik. 8vo. Frankfurt-aM., I87I.

Hahn, K. A.-Althochdeutsche Grammatik. 8vo. Prag, 1875.

Halbertsma, J.-Lexicon Frisicum, A to Feer. Royal 8vo. Haarlem, 1872.

Helfenstein, Dr. Jas.-Comparative Grammar of the Teutonic Languages. Royal 8vo. London, 1870.

Hettema, M. and P. R. Posthumous.-Onze Reis naar Sagelterland (containing a grammar and word-list of that dialect). "8vo. Franeker, 1836 .

Hettema, $M$.-Proeve van een Friesch en Nederlandsch Woordenboek. 8vo. Leeuwaarden, 1832 .

Hettema, $M$. - Jurisprudentia Frisica, een Handschrift uit de vijftiende eeuw. 8vo. Leeuwaarden, 1834 .

Hettema, M.-Idioticon Frisicum. Imp. 8vo. Leeuwaarden, 1874 .

Hettema, M.-Oude Friesche Wetten. 8vo. Leeuwaarden, 1846 .

Hettema, M.-Het Emsiger Landregt van het jaar 1312. 8vo. Leeuwaarden, 1830 .

Hewitt, W. T.-Frisian Language and Literature, an Historical Sketch. 8vo. Ithaca, New York, 1879.

Heyne, M.-Altsächsische Grammatik. 8vo. Paderborn, 1873.

Heyne, M.-Altsächsisches Glossar, in his edition of the Hêliand. 8vo. Paderborn, 1873 .

Heyne, M.-Kleinere Altniederdeutsche Denkmäler. 8vo. Paderborn, 1867 .

Heyne, $M$.-Kurze Laut und Flexionslehre der Altgermanischen Dialecte. 8vo. Paderborn, 1874 . 
Hoeufft, J. H.-Taalkundige Aanmerkingen op eenige Oud-Friesche Spreekwoorden. 8vo. Breda, I8I2.

Japicx, G.-Friesche Rijmlerye, ed. Epkema. 4to. Leeuwaarden, 1821 .

Leo, H.-Angelsächsisches Glossar. Royal 8vo. Halle, i872.

March, $F$. A.-Comparative Grammar of the Anglo-Saxon Language. Royal 8vo. New York, 1875.

Motley, J. L.-The Dutch Republic. 3 vols. 8vo. New York, 1880. Müller, F. Max.-Lectures on the Science of Language. 2 vols. 8 vo. New York, 1875 .

Ottema, Dr. J. O.- Thet Oera Linda Bôk, English edition. 8vo. London, 1876 .

Outzen, N.-Glossarium der Nordfriesischen Sprache. 4to. Kopenhagen, 1837 .

Rask, R.-Anglo-Saxon Grammar, by B. Thorpe. 12mo. London, 1865.

Rask, R.-Frisische Sprachlehre aus dem Dänischen übersetzt, von Dr. F. J. Buss. 12mo. Freiburg-im-Braunschweig, 1834.

Rask, R.-Friesche Spraakleer mit enige veranderingen uit het Deensch vertaald door Mr. M. Hettema. 8vo. Leeuwaarden, 1832.

Rask's Icelandic Grammar. 8vo. London, 1869.

Richthofen, $K$. F.-Friesische Rechtsquellen. 4to. Berlin, 1840.

Richthofen, K. F.-Altfriesisches Wörterbuch. 4to. Göttingen, 1840. Rieger, M.-Alt-und-Angelsächsisches Lesebuch nebst Altfriesischen Stücken. 8vo. Giessen, I86I.

Schmeller, J. A.-Hêliand. 4to. Monachii, \&c., I830-40.

Sievers, E.-Angelsächsische Grammatik. 8vo. Halle, r882.

Stürenburg, C. H.-Ostfriesisches Wörterbuch. 8vo. Aurich, 1862. Sweet, H.-Anglo-Saxon Reader. 12mo. Oxford, 1876 .

Sytstra, H. S.-Klank-schrift en Woorden-leer der Friesche taal. 8vo. Two parts. 1856-62. 
Von Wicht, M.-Ostfriesisches Landrecht. 4to. Aurich, 1738. Wackernagel, W.-Altdeutsches Wörterbuch. 8vo. Basel, I878. Wiarda, T. D.-Altfriesisches Wörterbuch. 12mo. Aurich, I786. Wiarda, T. D.-Asega-Buch. 4to. Berlin und Stettin, 1805. Wiarda, T. D.-Willküren der Brokmänner. 8vo. Berlin, 1820. Williams, M.-Sanskrit-English Dictionary. 4to. Oxford, 1872. Winkler, J.-Algemeen Nederduitsch en Friesch Dialecticon. 2 vols. 8vo. 'S Gravenhage, 1874 .

Zeuner.-Die Sprache des Kentischen Psalters. 8vo. Halle, 1882. 


\title{
FRIESIC GRAMMAR.
}

\author{
PARTI.-PIHONOLOGY.
}

\section{THE ALPHABET.}

$(y), z$.

$a, b, c, d, e, f, g, h, i, j, k, l, m, n, o, p,(q), r, s, t, u, v, w,(x)$,

\section{SOUNDS OF LETTERS.}

\section{VOWELS.}

(1.) $a$ like $\mathrm{a}$ in lad. $\hat{a},, a$, , ball. $e$, , e , rest. $\vec{e}$, , e , they. $i$,, i , hit. $\hat{\imath}$ like ee in seem.

$o$, o , blot.

$\hat{o},, \quad$ o , dome.

$u,, \mathrm{u}$, , full.

$\hat{u}$, , oo , tool.

(2.) There was but little difference between the sounds of $a$ and $o$ in such words as man, mon, land, lond, wald, wold. Regarding the free interchange of these vowels with each other see section 3 .

(3.) The same is true of $e$ and $i$ at the end of unaccented syllables; we find them indiscriminately used, as in hire, hivi, nose, nosi, \&c.

(4.) The vowels rarely had an absolutely determinate sound, being subject to innumerable shades and slight variationsmuch like the varied shades of colours that are so prevalent, to which but seldom can an absolutely distinctive epithet be applied; and, then, again in the senescence of the language the sounds assimilated themselves to those of the conquering and absorbing dialect of Holland. 


\section{CONSONANTS.}

2. (I.) The consonants are pronounced as in English, with the following exceptions:-

(2.) $c$ pronounced always like $k$.

(3.) $c h$ like the German $c h$; it is the equivalent of the Anglo-Saxon hard $h$, as in brôchte, A.-S. bróhte.

(4.) $h$ before all consonants, but $w$ is but a slight aspirate, as in hlâpa, to leap; hrof, robbery. Sometimes pronounced so indistinctly as to be omitted from words, as ors for hors; and from the same word the $r$ was occasionally dropped, making hos, which sounds like the vulgar or backwoods pronunciation of English horse.

$h w=w h$ in what.

(5.) $j$ before a vowel pronounced like English $y$.

(6.) $k$ sometimes is pronounced like $c h$ and $s h, \& c$. ; but as to this see under gutturals.

(7.) $l f$ and $l v$. In these combinations the Frisians were inclined to absorb the $f$ or $v$ in the pronunciation, and thus wrote indiscriminately dêla or delva, to delve; bihale or bihalva, beside; $c f$. the Scotch sel' for self.

(8.) $s$ finally assumed the Dutch sound of $z$, and sonder was pronounced zonder; syn, zyn, \&c.

(9.) $w l$, wr. In the combination $w l$, the $w$ has something of the sound of the German $w$, as in wlite $=$ vlite. Before other consonants the $w$ is but slightly, if at all, pronounced; accordingly the manuscripts exhibit wrogia, rogia, wriust, riust, wrauld, rauld, \&c.

Other remarks regarding pronunciation will be found scattered through the following sections, composing Part I. of this work.

\section{VOWELS.}

Short vowels- $a, e, i, o, u$.

Long vowels- $\hat{a}, \hat{e}, \hat{\imath}, \hat{o}, \hat{\imath}$.

Diphthongs-iu, ei, au, eu, ou.

3. (I.) Original $a$ (i.e., that of the parent Old Low German) is preserved before $m$ and $n$, whether single, geminated, or 
combined with a mute, and also before a single consonant with $a$ or $u$ in the following syllable, as in nama, name; fara, traveller; although this vowel manifests a tendency to change to $o$ before nasals, as in man, mon; kamp, komp, fight; but a can never change to $o$ where the umlaut occurs.

(2.) $a$ represents Goth. $a$ and the simple A.-S. ea, as in $a l$, all, Goth. alls, A.-S. eall ; half, half, Goth. halbs, A.-S. healf.

(3.) An $e$ for original $i$ in the final syllable gives rise to umlaut, as in hangst, gen. hengstes.

(4.) a frequently becomes $e$ before two consonants, but generally remains unchanged before $l, x$, and geminated mutes, as in falla, to fall; snabba, mouth; katte, cat; salt, salt ; walda, to rule; sax, knife; but before $r$ e appears, as in herd, hard, Germ. hart, Icel. harør: exceptions-barn, child; garda, a garden.

4. (I.) $e$ is derived from three other vowels, viz., $a, i$, and $u$; from $a$ by umlaut, as in hangst, hengstes; lemithe, laming ; and by a simple weakening of the sound before two consonants, as indicated in section 3.

(2.) It is derived from $i$ by the power of assimilation exercised by an $a$ in the following syllable, as in helpa, to help, it being considered that this $e$ was so indistinctly enunciated as much to resemble $a$. It does not change back, as in A.-S., O.-S., and O.-H.-G., in the strong conjugation of the verb, and we consequently have werpe, werpst, werpth, helpe (helpst), helpt.

(3.) It appears for $u$ after that vowel has been intermediately changed into $o$, as in $f e l$ for $f u l$, much; ken, genus (O.-H.-G. chunni).

(4.) In the participles bifelen, breken, broken, \&c., the $e$ represents the vowel of the infinitive where other verbs have $o$, as in A.-S. gebrocen, and the parallel form in Friesic, bifôlen; so beren and boren; nimen, O.-S. (bi-)noman, stelen.

(5.) Its correspondences are-first, A.-S. and Icel. $e$, as in setta, to set, A.-S. settan, Icel. setja. Second, the A.-S. "fracture" $e a$ (fracture of $a$ ), Icel. $e$, or $a$ changeable to $e$ by umlaut_bern, child, A.-S. bearn, Icel. barn (bernska); erm, 
poor, A.-S. earm, Icel. armr. Third, A.-S. $\alpha$, as in gers, A.-S. goers, grass; wetir, A.-S. woeter, water. Fourth, A.-S. eo, (fracture of e), berch, mountain, A.-S. beorh; melok, milk, A.-S. meoloc.

\section{EUPHONICALLY INSERTED $e$.}

5. When in Gothic a mute is followed by a liquid or a nasal, and one of the latter forms a syllable by itself without the help of a vowel, as in akrs, fugls, taikns, maipms, there is generally developed in Friesic an intrusive euphonic vowel before the consonant: thus in ekker, acre, ager; fugel, fowl; têken, token, sign. Unlike A.-S., O.-F. presents only e; so in winter, Goth. wintrus; finger, Goth. figgrs; appel, A.-S. axpl. Metathesis occurs in axle (also axele), shoulder; nêdle, nîdle, needle.

6. (x.) $i$ pure is preserved before many combinations beginning with $m$ and $n$, and before $r$ with a dental following, where A.-S. has eo: binda, to bind; hirte (also herte), A.-S. heorte: but $u$, or its representative $o$, in the following syllable, causes it to yield to $e$, as in felo, much; fretho, peace; selover, silver.

(2.) $i$ is fractured to $i u$ before cht, as in riucht, right, law; fliucht, he flies. Fracture also seems to occur in tziurke, church ; wriust, wrist ; and tziust (kiust), a fell, pelt.

(3.) It appears for $a$, or its umlaut $e$, in skil, shall ; while the second person has skalt: in tzilik, kilik, calix; hiri, army ; wirid, pret. part. of wera, to defend; for $u$ in skila, shall; kining, king; kin, kin, O. S. kunni-but of these last two words the umlaut forms occur; kening and ken; also skela for skila.

(4.) It corresponds to A.-S. $i, y$ (and eo, as has above been observed), and Icel. $e$.

Mith, with,
Nima, to take,
Irthe, earth,
Hirte, heart,
Fir, far.

A.-S. mið, Icel. $m e \%$.

"niman or nyman, " nema.
eorðe.
" heorte.
feor.


7. $o$ is generally the representative, the "Truibung" or obscuration of $u$; before $m p, n d$, and $n$ it is a mere variation of $a$, as in komp, kamp; lond, land; hond, hand; gong, gang, a going, walking; mon, man. It is equivalent to A.-S. $o$ and the $o$ of the other dialects.

Dolch, wound, A.-S. dolh, Mod. Fries. dolge and dolck. Folk, folk, " folc. " folck.

8. (I.) $u$ is but seldom preserved; it has given way so extensively to the "Trubung" in $o$. It corresponds to A.-S. $u$.

$\begin{array}{lc}\text { Hundred, } & \text { A.-S. hundred. } \\ \text { Tunge, tongue, } & \text { tunge. }\end{array}$

' (2.) Organic generally before nasal combinations-grund, ground; tunge, tongue.

(3.) $u=$ O.-H.-G. o in thuner, thunder, O.-H.-G. donar; kuma (also parallel form koma), O.-H.-G. coman, queman; wuna (also wona), to dwell, inhabit, O.-H.-G. wonên. Also to Latin $o$ in words from that language, munek, munik, monik, L. monachus; pund, pound, L. pondus.

(4.) $u$ for $a$ in gunga, to go ; it is very frequently written for $v$ and $w$; for $v$, as in erue, heir; oua, over; for $w$, as in tud, two; wedue, widow.

\section{LONG VOWELS.}

9. (I.) $a$ occurs in some cases of contraction, as in $f \hat{a}$ (Germ. fangen), to take, seize; sla (Germ. schlagen), to strike.

(2.) It appears in the third person plural of the eighth class of strong verbs, as in nâmon, from nima, to take.

(3.) It represents Goth. ái and A.-S. á, as in ham, A.-S. hâm, Goth. hâims; âga, to have, Goth. áigan; but it is most frequently found in the place of the Gothic diphthong $a u$, which appears in A.-S. as eá.

E.g., âre, ear ; age, eye ; hlâpa, to run; gâ, a town, region, or district (Germ. Gau); for Goth. áuso, áugo, hláupan, 
and gáuja. Its other equivalents are Icel. au, O.-H.-G. o, as in-

$\begin{array}{lccc}\text { Dâd, death, } & \text { A.-S. deád, } & \text { Icel. dauðr, } & \text { O.-H.-G. tôd. } \\ \text { Râd, red, } & \# \text { reád, } & \text { "rauðr, } & " \text { rôt. } \\ \text { Lâs, loose, } & " \text { leás, } & \text { "laus, } & \text { lôs. } \\ \text { Strâm, stream, } & \text { "streám, } & \text { "straumr, } & \text { Mod. ver. (Strom). }\end{array}$

(4.) It appears in the singular preterit of the eighth class of strong verbs, as $k a \hat{s}$, from liusa, to choose ; bad, from biada, to command.

(5.) There is some vacillation between $\hat{a}$ and $\hat{e}$, as in the words flask, flesh, klath, vestis, hladder, ladder-in the Hunsingoer Recht flêsk, klêth, hlêdder; and then, vice versâ, gâstlik in it for jêstlik in the other.

10. (I.) $\hat{e}$ represents O.-S. $\hat{e}$ instead of O.-H.-G. $e i$, as in brêd, broad, O.-S. brêd, O.-H.-G. breit.

(2.) It sometimes represents O.-H.-G. $\hat{e}$ and A.-S. é instead of ie, as brêf, bêr, prêster, for brief, bier, priester.

(3.) It is equivalent to A.-S. é, as in fêt, A.-S. fét; dêma, to judge, A.-S., déman; fêra, to go, to lead, A.-S. féran.

(4.) It also represents A.-S. $a$, ó, and Icel. $a$.

$\begin{array}{llr}\text { Hêr, hair, } & \text { A.-S. hacr (hér), } \quad \text { Icel. hâr. } \\ \text { Dêde, deed, } & " \text { dacd, } \\ \text { dêla, to divide, } & " \text { dólan. } \\ \text { ênich, any, } & \Rightarrow \text { ánig (Kentish, délan, énig). }\end{array}$

(5.) It also represents A.-S. $y$ and Icel. ey.
Lêsa, to loose,
A.-S. lysan,
Icel. leysa.
Hêra, to hear,
" "hyran,
" heyra.

(6.) It occurs, as in A.-S. eâ, or its contraction é, as a condensation of Goth. áu.
$N e ̂ d$, need,
A.-S. néd,
Goth. naiubs.
Dêpa, to dip,
Skêne, pretty,
(Germ. schön),
" daupjan.
" skáuns.

(7.) The condensed form $\hat{e}$ appears also for the Gothic diphthong iu, A.-S. éo ; grêt, grit, sand, A.-S. greót ; knê, Goth. kniu; binêta, to rob, deprive, O.-S. biniotan. 
(8.) $\hat{e}$ represents the contraction of the diphthong $e i$, as in $\hat{e} n$, one; swêpa, to sweep, Icel. sveipa; lêda, to lead, Goth. ga-leiban; hêt, hot, Goth. * heit.

(9.) $\hat{e}$ is employed to indicate the umlaut of $\hat{o}$; dôm, judicium, dêma, to judge; fêla, to feel ; wêpa, to weep; grêta, to greet.

It is even so employed with respect to $\hat{\imath}$, as in sêle, Germ. Säule, pillar ; hêde, hide, A.-S. húd, corresponding to the A.-S. umlaut of $u$, which is $y$.

(ro.) In a few instances this vowel has been retained in pure correspondence with Goth. $\hat{e}$, as in mêl for mâl, time; wêpen, weapon, for wâpen; wêron, they were; jêvon, they gave. As intimated in these instances, the vowel $a$ corresponds generally in this and the other old Teutonic dialects to Goth. $\hat{e}$.

This vowel will frequently be found written thus, ee, as $\hat{\imath}$ is written $i i$, and $u, u u$.

11. (I.) $\hat{\imath}$ represents the Gothic diphthong $e i$, and answers to $\hat{\imath}$ in the other old Germanic dialects; e.g., Goth. hweila, a time, O.-H.-G. hwîla, O.-S. hwîla, A.-S. hwîle, Fries. hwîle, Saterlandish wîla, North Fries. wîle; Goth. preis, three, O.-H.-G. drî, A.-S. thri, Icel. brîr, Fries. thrîa, thrice.

(2.) This vowel may also take the place of the ei arising from $e g$, as in $d \hat{\imath}$, day ; $m \hat{\imath}$, may.

(3.) It may result from contraction, as in $n \hat{\imath} a, n e w$, Goth. niujis; sîa, to sew, Goth. siujan.

(4.) $y$, which has in this dialect a proper place only in foreign words, is frequently found for $\hat{\imath}$, as well as $i$, as in wyf for $w \hat{\imath} f$, wife.

12. (r.) $\hat{o}$ equals Gothô, A.-S. ó, and Icel. $\hat{o}$, as inDôm, judgment, Goth. dôms, A.-S. dóm, Icel. dômr. Bôk, book, "bôka, "bóc, "bôk. Brôther, brother, " brôpar, " bróther, " brôđir.

(2.) It answers to Gothic nasal $\hat{a}$ for an, as in brôchte, brought, Goth. brahta, pret. of briggan = bringan; Fries. 
thôgte, Goth. báhta for banhta. It takes the place, as in A.-S., of Goth. $a$ before a nasal which has dropped out; as in otther, other, ander, Goth. anpar; so A.-S. gos (for gons), goose, Goth. hansa; A.-S. sófte, adv. softly, O.-H.-G. samfto.

(3.) So it represents Goth. $\hat{e}$ before a nasal in some words, as in môna, moon, Goth. mêna; mônab, month, Goth. mênôps; kômon, pret. plur. of kuma, to come, Goth. qêmun; nômon, pret. plur. of nima, to take, Goth. nêmun.

13. (r.) $\hat{u}$ represents Gothic $\hat{u}$ and $i u$, and the $\hat{\imath}$ of the other dialects. Goth. his, the same in Fries. and the other ancient dialects. Goth. fûls, foul ; Fries. fül, A.-S. fúl; Icel. full.

(2.) It is a contraction of $i u$, as in frudelf =friudelf, lover; kriose, kruis, cross ; flicht for fiucht, he flies.

(3.) It occurs in some other cases of contraction, as in hûa, to hang, for hangja.

\section{DIPHTHONGS.}

14. (r.) This dialect is restricted to the single diphthong $i u$, with the weakened forms $i a, i o$.

$I u$ appears at the end of words, as in thriu, three; hiu, she. Some words waver between $i u$ and io, as fiur and fior, four; diure and diore, dear; liude and liode, people.

The Rïstringer Recht seems to prefer $i o$, the other laws the form $i u$.

(2.) There was such a stress upon the pronunciation of this diphthong that in later Friesic, as in Heligoland, the consonant preceding fell away by aphæresis, leaving jûr for djûr, dear, jied for ljycht, O.-F. liucht, junk instead of diunk, dark, obscure. So in Sagelterland $d$ before the same is but slightly heard, as in $d j u, d j o p, \& c$. In Schiermonnikoog juued $=0$. F. liode, which retains the $l$ in the other modern dialects.

(3.) In the words $j a$, to confess, and sîa, to see, the $a$ must be considered as the infinitive ending-O.-H.-G. jëhan, sëhan;in tîa, to lead; fîa, to fly, which stand for tiaha, fiaha, the 
infinitive ending may have fallen away, the naked stem diphthong remaining.

\section{LATER DIPHTHONGS.}

15. (I.) $e i$ is usually an inorganic and later formation; it arises from the contraction of the terminations $a g$ and $e g$, as in wei, way, for weg; dei, day, gen. deges or deis; but in the plural the $g$ reasserts itself, and wegar, degar, \&c., appear.

(2.) In ein (also written ain), own, it is a contraction of $\hat{e} g$ = êgin, and heia = hêga, to fence, preserve.

(3.) For $\hat{\imath}$ taking the place of $e i$, see section 11 (2.)

(4.) The parallel forms deil for del, dale (O.-S. dal); weisa for wesa, to be ; beile for bel, boil, occur.

(5.) ei equals A.-S. a in eider, either, A.-S. aghwwaðer, aggter.
(6.) $e i=\hat{u}$ in O.-S., breid, bride, O.-S. brûd. $e i=o u$ in O.-H.-G., hei, a blow,
O.-H.-G. hou (hau).

(7.) There is another $e i$ which arbitrarily takes the place of $e$, as in O.-H.-G. and O.-S., or Frankish : thus in eifna, to level.

(8.) In keisar, emperor ; leia, layman, the $e i$ is identical with the same diphthong in O.-H.-G., from which, in fact, these forms are derived.

It is sometimes written $e y, m e y=m \hat{\imath}$, possum.

(9.) Sometimes ai occurs for ei, as in aider, eider, either; ain, ein, own.

16. $a u$ is an inorganic diphthong resulting from the contraction of $\hat{a} w$; naut for nâwet. It also sometimes stands for $\hat{a}$, as in auwa for âwa, to show; auber for $a b e r$, open, manifest. Again for al, as saut for salt.

17. $u i$ stands sometimes for $\hat{u}$, as in huisman, tenant.

18. eu, as in breud, a pulling (hêr-breud, hair-pulling; nosebreud, \&c.), from the verb $b r \hat{\imath} d a$, is another inorganic diphthong resulting from the loss of a $g$ in the verbal and nominal forms; thus brîda stands for brigda. 
19. $a e=\hat{a}$, generally, as aegh for âch, bistaen for bistân (Germ. bestehen). It also occurs for $\hat{e}$, as in haet for hêth, has; aerst for êrost, first ; waepen for wêpin. It but seldom occurs in the Rüstringer Recht and other old texts.

20. oe is usually the later and Dutch orthography for $u$, as in bloed, blood; soen for sunu, son; hoemanich (quam multi), Dutch hoe menigerlei; doem, judicium (Older Fries. dôm), Dutch doemen, to judge.

21. ou is sometimes equivalent to Germ. au : broute $=$ Brau, a brewing. It forms a compensation sometimes for a lost $l$, as in goud, gouden, gold, golden ; houda for holda, friend : appears for th in ouder for ôther.

\section{The Consonants.}

Liquids- $l, r$.

Nasals- $m, n$.

Spirants- $v, w, s, z, j$.

Labials $-p, b, f$.

Mutes. Dentals- $t, d, t h$.

Gutturals-k $(c), g, h$.

$$
q=k w ; x=k s \text {. }
$$

\section{LIQUIDS.}

(ז.) $l$ and $r$. This dialect carefully distinguishes between the Gothic simple initial liquids $l$ and $r$ and their aspirated compounds $h l, h r, w l$, and $w r$ (so also with the nasal $n-h n) . \quad H l$ and $h r$ are sometimes found with the liquid and the spirant transposed, as $l h, \& c$.

(2.) These aspirated compounds dịd not descend to the modern dialects.

(3.) There is an elision of $l$ before certain consonants, as there is in the pronunciation in English-would, could, should (which, by the way, are written phonetically in Modern Friesic-woe'd, koe'd, scoe'd-by apocope woe', koe', 
scoe'), as in selîk, Goth. swa-leiks, such; salk, sêk ; sullîk, sulk, sulk; hwelikk, hwelk, hwêk, hôk, and hîk.

(4.) Gemination is rejected at the end of a word, and is not found in compound words where the preceding vowel is short, as $a l$, all; $a l-s \hat{a}$, also. In this it fully agrees with A.-S.

(5.) $r$ answers to ancient Germanic $r$, as in rike, kingdom; renna, to run; brenga, to bring; wer, man; Goth. reiki, rinnan, briggan, wair: to original $z$ in the middle of a word (Goth. $z$ or $s$ ), as in mâra, more, Goth. maiza; are, ear, Goth. auso; nêra, to support, foster, Goth. nasjan (to save).

(6.) A tendency to indulge in rhotacism (the change of $s$ into $r$ ) pre-eminently characterises Friesic ; e.g., it appears in the nominative plural of substantives, as in degar, days, A.-S. dagás; fiskar, fishes, A.-S. fiscás. Sometimes, however, the liquid entirely disappears, as in dega; the probability, therefore, is that the pronunciation of the $r$ was as indistinct as is that of the same letter now in England in such words as bar, tar, \&c.

24. There are many evidences of the fact that there has been a marked tendency in Friesic, as to a certain extent in English, to slur over and indeed neglect the pronunciation of both the liquids $l$ and $r$, though frequently with a vowel compensation.

$r$ is cast away as in A.-S. where not organic, as in $m \hat{a}$, more, Icel. meir; min, less, Icel. minnr or miðr.

25. $r$ is generally absorbed in the pronunciation of Modern Friesic words, as in thôn for thorn, hôn for horn, kôn for korn, been for kern ; beens-been, nepos; so kerne and herne are pronounced kenne, henne. The same thing occurs in the Westphalian dialect of the PlattDeutsch. So in Norwegian barnsdom is pronounced bansdom, \&c. Again, in M. F. boarstje, to burst, is pronounced boastje, while in another district there is elision of the sibilant, bart occurring for barst.

26. Metathesis is quite common, as in gers, grass; hars, horse (0.-H.-G. hros); fersk, fresh; barna, to burn (Germ. 
brennen); forst, frost. $E n$ for the negative ne occurs joined to another word, as $i k$ enhebbe, I have not.

\section{NASALS.}

27. (1.) Final $n$ is almost uniformly rejected in infinitives * (though it reappears in the gerund), in the termination of the subjunctive, in the inflections of the weak declension, and in various words; as finda, to find, A.-S., findan; thene hona, (acc. of gallus), instead of honan. The $a$ thus left answers in all cases to A.-S. an and on ; e.g., ma, A.-S. man, one; thana, thence, A.-S. banon; bûta, without, A.-S. bútan.

(2.) The Northumbrian dialect of the A.-S. presents examples of the rejection of final $n$ as in Friesic, in infinitives; e.g., ge-hálgia, to sanctify ; ge-cuma, to come; lócia, to look; weorthia, to honour; leornia, to learn; thenka, to think; hera, to hear ; ária, to honour; gonga, to go; habba, halda, tenere; honga, to hang, and many others. See the glossary to "Die vier Evangelien in Altnordhumbrischer Sprache," von K. W. Bouterwek.

(3.) The corrosion of centuries has further abbreviated the Frisian infinitive in some districts now to simple $-i$, as in the East Frisian words eeri, to honour, O.-F. êrja; gungi, to go, O.-F. gunga; macki, to make, O.-F. makja. Many verbal forms in Heligoland + and Wangerôg have, like the English, entirely lost the vowel of the infinitive in such words as bed, to bid; bü̈̈g, to bow; hiar, to hear; $i t$, to eat; lied, to lead; thênk, to think ; bring, to bring; sei, to sew; sliap, to sleep; deil, to deal with; bârg, to hide, A.-S. bergan ; bifel, to command, O.-F. bifella; bik, to pick ; bit, to bite; brik, to break.

(4.) We find the gemination of $n$ arising from the contraction of two $n$ 's, which have come into closer contact by the elision of one or more vowels, as in ênne for ênene, mînne for mînene, thînne, \&c.

* It appears, however, in kwân and seggen, bistân, adjurare, dicere ; sian, to see; bringan, to bring; wesan, to be; fân, to take; gân, to go; jân, to give; bi-schojan, Germ. beschauen, \&c. ; similar forms also prevail in M.-F., thas : géan, sjaen, stéan, jaen.

+ This island was Frisian as early as the eighth century, and received its name, Sacred Island, from its being the principal place of worship of Fosite, Norse, Forseti (?) According to others, of Odin. 
(5.) In this, as well as in other Old Teutonic dialects, inflectional $m$ has, when occurring in terminations, always been changed to $n ; n$ is dropped when occurring in the middle of a word before $s, t h, d$, and $f$, as in $2 t s$ (Germ. uns), nobis, ev-ềst, hatred (Goth. anst); gôs, goose, pl. gês, O.-H.-G. gans ; other, Goth. anbar; tôth, pl. têth, Goth. tunpus; sîth, Goth. sin bs; muth, fîf (Germ. mund, Goth. fimf): exception, winstere, left. ath appears for and in the plural terminations of the verb.

\section{SPIRANTS.}

28. (r.) $v$. and $w . \quad v$ is sometimes written at the beginning and in the middle of words for the vowel $u$-e.g., vrdrivva for urdriva, to drive out ; vr for ur, over; vtor, extra ; vndvnga, se liberare.

(2.) $w$ appears also for $u$ at the beginning and in the middle of words, and in some cases $w u$ is rendered by a simple $w$ wtward for $\hat{u} t w a r d$, outward; wrsîa for ursîa, to oversee; wnde for unde, wound; dwa for dîa, to do. Of $w$ for wu observe wllen, woollen; wnnen, won; and wrdon, become.

(3.) Of combinations we note $w l$ and $w r$ in wlite, visibilis, and wlemmelsa, laesio, which are combined in volitervlemmelsa, a visible wound (i.e., one not covered by clothing); wr in wrêka, ulscisci; wrôgja, accusare, and others.

(4) $w$ occurs with another consonant preceding, in the combinations $d w, h w, k w, s w, t w$, thw; dwâlicheed (Mid. Fr.), error; hwâ, who; kwetha, to say; swerd, sword ; twâ, two; thwinga, to force, compel.

They are, as a rule, strictly preserved from intermixture with the succeeding vowel.

(5.) Where $w$ occurs in New Friesic it is almost uniformly strongly aspirated, sounding like English wh in where.

(6.) The A.-S. vocalisation (i.e., $w$ after another consonant and before $i$ is vocalised into $u$, the $i$ being dropped) is admitted in the following cases:--suster, sister; kuma, to come ; and kom, came; for svister (Rüstringer swester); kvinza, kvam.

(7.) $w$ is sometimes dropped in the middle of a word, as in 
sêla, A.-S. sáwel, soul, life ; hîskthe, family, O.-H.-G. hîwisca ; ondsêra for ondswêra, to swear free; tôlef, tôlefta, twelve, twelfth, for twilif, tuilifta; sîaring for swiaring, son-in-law; and at the end it is sometimes retained and sometimes falls away, in the latter case lengthening the preceding vowel. Retained, as in $d \hat{a} w$, dew; blâw, blue : falls away, as in $g \hat{a}$, a district, vicus; $\hat{a}$, a law. The $w$ has developed no diphthong, but simply a long vowel in frôwe, woman; hâwa, to hew; strêwa, to strew'; bûwa, to build.

(8.) The $u$ in such forms as fiuwer, four; triuwe, faith; hauwen, hewn, is, so to speak, but a diphthongal gemination of the $w$, for fiwer, triwe, hawan-a peculiarity also observable in O.-H.-G.

(9.) $v$ replaces the nasal $m$ in fôvne for fâmne, fômne, woman, maid : drops out of skrîn for skiviven, written; jondis for avend, evening.

29. (I.) $s$ and $z$. Rhotacism of $s$ into $r$ takes place as in O.-H.-G. and O.-S. The $s$ is preserved in the present and preterit singular of strong verbs; while the preterit plural and the participle adopt $r$, e.g., kiase, kâs, keron, keren; wesa, was, wêron.

(2.) The softening of $s k$ into $s c h$ is a dialectic peculiarity : before $e$ and $i$ we find schet, treasure; schel for skel, shall; scheldech, guilty ; schilling, shilling: before $a$ and $u$ in schangt, present; schule, shelter, hut.

(3.) The soft sibilant $z$ is found at the beginning of but few words, and there mostly appears in later forms in sympathy with, and under the influence of, the Dutch, as zeerâwer, pirate, viking, Dutch zeeroover; zwarra, to swear, Dutch zweeren.

For the combinations $t z, s z, d s z, d z$, \&c., see under Gutturals, section 36.

30. Contrary to the custom of some of the other Old-Germanic dialects, which often supplant $j$ by $g$, the Old Friesic has, in addition to the organic $j$, employed this consonant in the place of $g$ (the $j$ is written $i$ in the manuscripts, and has usually been so printed), e.g., jeld, poena, pecunia, for geld; 
jeva, to give, \&c. The spirant is organic in jêr, year; jung, young; federja, patruus; makja, to make; sparja, to spare; erja, to honour. It is ordinarily vocalised into $i$ where it forms part of the root, and is therefore seldom to be met with; e.g., nîa, new ; frî, free. When once vocalised it does not reappear in the word-hiri, army, has not in the dative hirji, but hiri.

\section{MUTES.}

\section{A B I A L S.}

31. (т.) $p$ in general and $b$ and $f$ at the beginning of words are organic; $b$, except in the combination $m b$ and in cases of gemination, is replaced by $v$ in the middle, and by $f$ at the end of words ; e.g., wîf, genitive, wîves ; stef, staff, dative steve; half, genitive halves; but $f$ remains in the middle of a word where a $t$ sound follows, as in efter, after; hâfd, head; jeftha, or. The labial aspirate $p h$ is represented by the spirant $f$ or $v$.

(2.) $p$ is identical in its relations with the same letter in the other Old-German dialects. Initial $p$ is practically a foreign letter to the Old-Teutonic tongues.

The gemination $f f$ occurs only in foreign words, and $p p$ is rare.

(3.) $f$ renders the A.-S. combination $h w$ in the word $f i a l$, wheel, A.-S. hweol, Icel. hvel, Swed. and Dan. hjul. This form is analogous to the ancient and modern Dutch wiel. There is an obvious and natural affinity between the labial and the spirant, which has resulted in the interchange in this instance, regardless of its combination with the aspirate.

(4.) A remarkable rendering of Latin $p$ is found in prôgost (prôvest), Lat. propositus, where a guttural replaces the spirant ; A.-S. profast, Icel. proffastr. We also find the same consonant taking the place of the labial media in sigun, seven. $C f$. also prôgja for prôvja, to prove ; also $j o g$ for $j o f$, gave; pagus for paus, pope. This consonant might, with a considerable degree of appropriateness, be denominated a guttural spirant. This applies as well to the guttural under the same circumstances in the modern Saterlandish dialect; e.g., ôgen for ôven. Observe also O.F. tonghere for thuner, thunder; sogenja for somnia, to collect. So ch occurs for $f$ in stichte (Ger. Stift), church, monastery, O.-H.-G. ga-stifte, aedificium. 


\section{DENTALS.}

$$
t, d, t h \text {. }
$$

32. (r.) $t$ is almost uniformly organic; it sometimes drops out at the end of a word after ch, as riuch for riucht; and th sometimes loses the aspiration and becomes $t$, as in nimat for nimath ; klît for klîth, clothing; dât for dâth, death; and vice vers $d$, th frequently occurs for $t$, as weth for wet, wet; with for wit. This peculiarity is principally characteristic of the $\mathrm{Em}$ siger Recht, the aspirate being partial to the end of a word. Thus, in the West Lauwers laws of 1276 , senth for send, wth for $\hat{\imath} t$, fôth for fôt.

(2.) $d$ when initial is organic. The media is liable, as in Gothic, to yield to the aspirate when terminational, but does not in such words as breid, bride; hafd, head; bed, asked; but the aspirate prevails in the terminations of the verb, -th and -ath occurring for $d$ and $-a(n) d$. $\quad r d$ and $r t h$ are kept distinct, as in gerdel, girdle; irthe, earth: $l d$ may be either organic or take the place of $l t h$, as holda, to hold, Goth. haldan; bilde, O.-S. bilithi.

(3.) The gemination $d d$ corresponds to $d$ with an original formative $-i$, as in bed, gen. beddes, Goth. badi; bidda, Goth. bidjan; thredda, third, Goth. pridja.

(4.) The media is sometimes inserted in a word for the sake of euphony-to give a full and forcible sound-much as $\beta$ is found in Greek words like $\gamma \alpha \mu \beta \rho \delta s, \mu \epsilon \sigma \eta \mu \beta \rho i a$, \&c., and in the Friesic nember for nimmer, never. Thus, in êtmelde, pl. of êtmel, a space of time; dey and nacht, jeftha twa êtmelde, day and night, or two divisions of time. So in from $(d)$ sind, the first synod-a judicial day. Then, again, it drops out of a word, as jel for jeld, garja for gadurja.

33. (I.) $t h$. The aspirate is made to answer (written $t h$ ) to both A.-S. and Icel. $p$ and $\gamma$; it undoubtedly had a softer sound in the middle and at the end of words than at the beginning.

(2.) The aspirate and media occasionally interchange, as sada for satha, sod; steth for sted, place, stead; keddes, gen. of ketha, nuntius.

(3.) Observe the change of the dental aspirate into the 
sibilant in strot for A.-S. throte, throat, and tosch for tôth, tooth; the dental aspirate for the spirant $f$ in midrith for midrif.

34. The pronunciation of the voiceless stopped consonant th has been practically lost among all the Continental members of the Germanic race, but retained among the islanders: e.g., in Fôr and Amrum we find thaank, thanks ; thârp, village; thiif, thief ; thing, thing, \&c. Wangerôgian thwong, thong; thacke, thatch; thîm, thumb; thitsel, thistle, pronounced as in English.

35. The inhabitants of the islands above enumerated distinguish between the sharp and soft aspirate. When the true pronunciation is being lost among them, they substitute the tenuis for the sharp and the media for the soft, and even follow up the exceptions that we have in English, as in this, that, than, the, thee, then, there, they, thou, thine, though, thus, which begin with the soft instead of the sharp aspirate; therefore there are presented, dizze, dat, dan, de or di, dinne, daere, $d y$, dou, dine, doghs, doz. These dialects, from their insulated position, and consequent retention of many Old-Friesic peculiarities, shed much light upon the ancient phonology.

\section{GUTTURALS.}

$$
k, g, h \text {. }
$$

36. $k$ is frequently - principally in the combinations $c l, c n$, $c r$, sc, and at the end of words-represented by $c$, as in clage (Germ. Klage), complaint; clinna (Germ. klingen), to ring, resound; merc, mark; comp for komp or kamp, pugna. $k$, and not $c$, is used before $e$ and $i$, as in kemen, come; kiasa, to choose : the tenuis is but rarely geminated, as in eliker, acre; smek, taste, genitive smeklies; stok, stolikes, stick. It was pronounced with so strong an aspiration in a number of words, as in ketel, kettle; kerke, church; rêka, to reach, that they were frequently written as detailed in the next section.

$x=k$. 
37. (r.) Very peculiar is the conversion (alluded to above) of a guttural into a palatal, which occurs as follows, and for the reason just given.

Before $e$ or $i$, at the beginning of a word, $k$ was frequently replaced by a palatal sound written thus- $s z$ and $s t h$ when the $e$ or $i$ was followed by a single consonant or a liquid, as in szin for kin, chin; sthereke for kerke, church.

(2.) At the beginning of a word $g$ was not thus affected. $g g$ in the middle of a word is replaced by $d z$, and $k$ by $t s, t z$, $t s z$; thus in sidza for sigga, segga, to say, though sometimes vocalised, as in leia, to lay, ditsa, to ditch; the English equivalent is an evidence of the same tendency in our own language: ditch is the modern pronunciation of A.-S. dic. This peculiarity is also characteristic of Modern Friesic.

(3.) After a consonant $s z$ and simple $z$ are written for this letter, as brensza, to bring (brenza); ledza, to lay.

(4.) A simpler mode of rendering the palatal is adopted in West Frisian in the employment of a simple $z$ or $s$.

(5.) With reference to the pronunciation, we may conclude that $t z, t s$, and $s t h$ represented the Anglo-Saxon weak $c$, or the Italian $c e, s z$ the English $s h$, and $d z$ the $g$, in such words as genius, general, \&c. The tenuis remains in but few wordskeda, chain; kerva, to carve; kersten, Christian; kempa, champion, \&c.

(6.) The Friesic method of spelling some proper names is interesting ; for instance, Rîtsard, Edzard, Wîtsard, \&c., which recall the French, Provençal, and Italian orthography, Richard, Rizard, Ricciardo, \&c.

38. (I.) $g$ is sometimes (when preceding $e$ or $\hat{e}$ ) rendered by the spirant $j$, as in jeva, to give; jelda, solvere, jêstlika, ecclesiasticus. This usurper has assumed even a more prominent place in the modern Friesic dialects.

(2.) When $g$ is preceded by $e$, and followed by $e$ or $i$ in the middle of a word, it is vocalised, and forms with the preceding $e$ the diphthong $e i$; thus rein, rain, from regen; brein, brain, from bregen; neil, nail, from negel.

(3.) Occasionally the diphthong thus formed is then con- 
densed into $\hat{\imath}$, so we find brîn in place of brein, nîl for neil, \&c. If any other vowel follows it remains, as in degar, days.

(4.) The prefixes $g$-, je-, gi- drop the initial consonant, as unge, let him go, ungath, they go, for gunge, gungath; so jutth, he pours out, from giata (Germ. giessen).

(5.) At the end of a word, when $e$ precedes it, $g$ may be changed to $i$, as in dei, day ; mei, may; wei, way. This is also a peculiarity of Kentish Anglo-Saxon, to be found in certain charters. This letter undoubtedly partook in a great degree of the character of a spirant.

(6.) At the end of a word $g$ can rarely occur in any but the combinations $n g$ and $g g$; it, therefore, always appears there otherwise as ch, as in berch for berg, orloch for orlog, war, contest. Observe, nevertheless, the following exceptions : iênig for ênich, any; arg, bad (a. 1499); tiug, tioeg, testamentary evidence, for thiuch.

(7.) In the same manner this consonant and $k$ are always changed into $c h$ before inflectional $t$, as in machte, might, from mega; sôchte from sêka, to seek; fliucht from fliaga, to fly.

39. $h$ only occurs at the beginning of words, where its pronunciation must have been very obscure, for it frequently falls away. In the middle it is sometimes dropped and sometimes hardened into $g$; e.g., sîa, to see (Germ. sehen) ; slôgon, they slew, from slâ. It inorganically begins êrost; thus hêrest in the Huns. Recht. At the end of a word it appears as ch, corresponding to A.-S. $h$; hach, high, A.-S. heáh; and so in the middle of a word, like $g$ and $k$ before $t$; dôchter, daughter, A.-S. dóhtor ; drochten, dominus, A.-S. dryhten, O.-S. drohtin ; brôchte, A.-S. bróhte. $h$ is inorganic in hâga, to have, and in the conjugational forms we sometimes find it dropped, as âch and $h a \hat{c} h$. The combination $h w$ is common, as in hwa, who; hwerpa, jacere; hwît, white. Other combinations, $h l, h r, h n$;

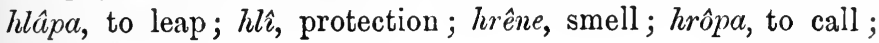
hnekka, neck.

\section{OMISSION OF CONSONANTS.}

40. Many consonants fall away in the inflections, and we find a number of contractions, such as netth for ne hêth; nêt for 
ni wêt ; sêt for sê hit; hôk for hwelîk, nêl for ne wil, sântich for sibuntich, seventy, \&c.

\section{ACCENT.}

41. The accent in Friesic, as in other Indo-European tongues, fell upon the root syllable of the word. The lack of poetical remains otherwise, however, throws much obscurity upon the subject.

\section{EUPHONIC CHANGES.}

\section{ABLAUT.}

42. Ablaut is a modification of vowels in the root of strong verbs to express past time, as finde, I find; fand, found; drîve, drêf, drive, drove.

\section{APOCOPE.}

43. Apocope is the cutting off or omission of the last syllable or letter of a word; e.g., in "fon there suster' and fon there modere;" "sâ skelin al' under êna swêra;" suster' being for sustere, and al' for alle.

\section{BRECHUNG, OR "FRACTURE."}

44. Brechung, or "fracture," may be defined as the change of one sound into two under a consonantal influence. Thus we have riucht for richt, right, law ; kniucht, knight, servant ; siucht, sight. It appears, as in the examples, most regularly when $i$ precedes the letters cht. It seems also to present itself in tziurke (Rüst. sthereke), church ; wriust, wrist; tziust, pelt; and dyoncker, obscurus.

In West Friesic $e$ before $l$ is fractured, as in ielder, elder; ielne, ell ; ielkers, alias.

\section{COMPENSATION.}

45. When a consonant is dropped in a word, the preceding vowel is lengthened-e.g., $\hat{u} s$ for uns, fiff, Goth. fimf; so if a preceding vowel or vowel and consonant be dropped, as 
früdelf for friudelf; bi-bâd from bi-biada; krîs for kriose; bi-skên instead of bi-skehen; eiên for jehen, pret. part. of $j a$, to confess, admit.

\section{UMLAUT.}

46. (r.) Umlaut is a change of vowel in the root produced by the influence of $i$ (or $e$ for original $i$ ) in the following syllable. It consists of a partial or complete assimilation of the root vowel to that of the following syllable. It changes $a$ to $e$, and $\hat{o}$ to $\hat{e}$; thus, wald, weldech, powerful ; hangst, hengstes, dôm, judgment; dêma, to judge.

(2.) When an ancient $i$ has been lost, its umlaut is termed "concealed," as in fôt, foot, pl. fêtt(i); man, pl. $\operatorname{men}(i)$; so dôm, judicium, dêma, to judge (the $i=j$ of a formative $-j a$, intermediately lost); her, army, in hertoga, dux, Goth. harjis. The only relics of the ancient $u$ umlaut (represented by $o$ ) are felo, much, many ; selover, silver; fretho, peace. 


\section{$P A R T I I$.}

\section{E T Y M O L O G Y. \\ THE NOUN.}

\section{GENDER.}

47. There are three genders - masculine, feminine, and neuter.

We must frequently look to the analogy of the Icelandic, Anglo-Saxon, and German for the gender of a word; it will, however, be found most closely to approximate to the German, as in-

Thet riucht,

Thi kâp,

Thi noma,

Thi berg,
Germ. das Recht,

" der Kauf,

" der Name,

" der Berg,
Icel, Rettr-in.

,$\quad$ kaup-it.

"nafn-it.

, berg-it.

48. The following are the general rules for gender :-

\section{Masculine.}

(1.) $a$. Names of males and nouns ending in $-a(-e l s a)$ or $-\imath$ : sunu, son; môna, moon ; lamelsa, laming; blôdelsa, bloody wound; hêra, lord ; thûma, thumb.

b. Nouns ending in -ath: môn-ath, month; somn-ath, gathering; twedn-ath, thrimen-ath, two-thirds, third ; thing-ath, complaint, process.

c. Nouns ending in -dôm: ein-dôm, ownership; frî̀-dôm, freedom ; kersten-dôm, Christendom. 
$d$. Most nouns ending in -el, -ul, -l: app-el, apple; gerd-el, girdle; him-ul, heaven; stap-ul, block; nei-l, nail ; ker-l, churl. So where there is metathesis of the -el, as in nîd-le, needle; sped-el, spek-le, spittle.

e. Nouns of agency ending in -ere: bog-ere, bowman; onthing-ere, complainant; sell-ere, seller.

$f$. Nouns ending in -ing: hîs-ing, tenant; êthel-ing, nobleman; wits-ing, viking.

$g$. Words ending in $-m a$ and $-m:$ bedsel-ma, bedstead ; set-ma, order ; brek-ma, fine ; âthe-m, son-in-law ; bose-m, bosom ; er-m, arm.

h. Participial themes in -nd: fîand, enemy; wîgand, warrior; werand, surety; friund, friend ; avend, evening.

\section{Feminine.}

(2.) a. All names of feminine persons, the sun, and nouns with any suffix terminating in -e, except-ere, -te, and two or three nouns ending in unaccented $-e$ (see under "Neuter"): frôwe, woman; tunge, tongue; thiuvethe, robbery; betteringe, improvement; fangnese, prison.

b. Nouns terminating in -eth: dug-eth (-ed), virtue; meg-eth, maid.

c. Nouns ending in -hêed(e), -êde, Germ. -heit: frî-hêd, freedom ; kersten-êde, Christendom ; falsk-hêde, falsehood.

d. Some nouns ending in -skip (e), Germ. schaft : friund-skip, friendship; dêl-skip, separation; but they are pretty evenly divided between feminine and neuter. Some are both feminine and neuter in different texts, like mond-skip, guardianship, \&c.

\section{NeUter.}

(3.) a. A few nouns ending in an -e, so indistinctly pronounced as frequently to fall away: rîke, rîk, kingdom; wêde, wêd, weeds, clothing; mere, news.

b. Most nouns ending in -en: têk-en, token; bêk-en, beacon.

c. Nouns ending in -sel, as mâk-sel, make, fashion.

d. Collective nouns terminating in -te: bêne-te, skeleton, bones; slach-te, race.

49. Nouns taken from other languages commonly retain 
the foreign gender, as thiu kamer, the chamber; thiu krône, the crown; thi engel, the angel.

50. Nouns of Different (Two or More) Genders.

\begin{tabular}{|c|c|c|c|c|c|c|}
\hline & 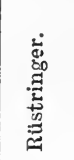 & 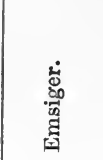 & 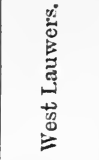 & 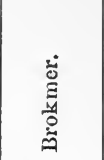 & 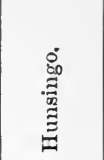 & $\frac{8}{8}$ \\
\hline Altêr, altâre, altar & Neut. & & Masc. & $\ldots$ & $\ldots$ & $\ldots$ \\
\hline Bôk, book & Fem. & F. & N. & $\ldots$ & $\begin{array}{l}\cdots \\
\ldots\end{array}$ & $\ldots$ \\
\hline Breke, bretse, ruptura . & & & M. \& F. & $\cdots$ & ... & $\ldots$ \\
\hline Dêl, part . & M. & M. & MI. & M. \& N. & $\cdots$ & $\ldots$ \\
\hline Fial, wheel. & $\ldots$ & N. & $\cdots$ & M. & M. \& N. & ... \\
\hline $\begin{array}{c}\text { Fiardunge, fiardeng, } \\
\text { farthing }\end{array}$ & F. & M. & $\ldots$ & ... & M. & $\cdots$ \\
\hline $\mathrm{He}(\mathrm{i}) \mathrm{lde}$, custody. & N. & & F. & F. & N. & $\cdots$ \\
\hline Hille, helle, hell . & F. & F. & F. \& N. & ... & $\mathrm{F}$. & ... \\
\hline Hivi, here, army. & M. & M. \& N. & MI. & $\dddot{\mathrm{T}}$ & M. & $\cdots$ \\
\hline Jeft $(e)$, jefta, gift. & $\cdots$ & N. & $\cdots$ & F. & F. \& N. & $\cdots$ \\
\hline Keme, coning, & $\cdots$ & F. & $\cdots$ & $\cdots$ & $\cdots$ & $\cdots$ \\
\hline $\begin{array}{l}\text { In on-keme, beginning - } \\
\text { In thruch-keme }\end{array}$ & $\dddot{\mathrm{iI}}$ & M. & $\cdots$ & $\cdots$ & $\cdots$ & $\cdots$ \\
\hline Kere, privilege & II. & $\mathrm{F}$. & M. & $\dddot{\mathbf{F}}$. & M. & $\cdots$ \\
\hline Merch, marrow - & $\cdots$ & N. & M. \& N. & $\cdots$ & $\cdots$ & $\cdots$ \\
\hline $\begin{array}{l}\text { Merk, boundary, in } \\
\text { composition }\end{array}$ & ... & ... & M. & $\cdots$ & F. & $\cdots$ \\
\hline Mondskip . . & $\cdots$ & $\cdots$ & F. \& N. & .. & $\cdots$ & $\cdots$ \\
\hline $\begin{array}{l}\text { Rene, running (in in-) } \\
\text { rene). }\end{array}$ & M. & M. & N. & $\cdots$ & $\cdots$ & $\cdots$ \\
\hline Skrift, writing . & 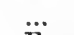 & F. & . & M. & M. \& F. & $\cdots$ \\
\hline Sted, place. & $\dddot{\mathrm{F}}$. & & M. & & $\ldots$ & $\ldots$ \\
\hline Tam, progeny & $\dddot{\dddot{H}}$ & M. \& F. & & M. & ... & M. \\
\hline Werth, worth & N. & M. & N. & ... & ... & ... \\
\hline
\end{tabular}

51. It is interesting to note how the natural has prevailed over the artificial gender in the case of the noun $w \hat{\imath} f$, which is grammatically neuter, and sometimes has the article, \&c., agreeing with it in that gender, but most frequently in the inflections the rational gender has struggled to the surface, and both the definite and indefinite article and the proper pronouns agree with or relate to it in the feminine.

\section{DECLENSION.}

52. There are five cases in Old Friesic, the Nominative, Genitive, Dative, Instrumental, and Accusative; and two numbers, the Singular and the Plural. 
53. There are two declensions, the Strong and the Weak; i.e., of nouns whose theme ends in a vowel (the strong), and those so ending in a consonant (the weak).

54. It may be interesting to observe that there are even fewer remnants of noun inflection in Modern Friesic than in English. Declension is accomplished by means of prepositions and the union of two nouns through the possessive pronoun, e.g., den mon, sin hîz; the man, his house.

55. The strong, or vowel declension, consists of three classes of nouns, viz., those of themes in $a, i$, and $u$.

\section{STRONG DECLENSION.}

Class I. - Themes in $a$.

\section{Masculine.}

$\hat{E} t h$, an oath. Theme, Êtha-

Singular.

Nom. êth

Gen. êthes (is)

Dat. êtha $i--e$

Acc. êth

Plural.

êtha $-r$

êtha

êthum -on -cm

êth $a-r$

Feninine.

Sêle, soul. Theme, Sêla-

Nom. sêle

Gen. sêle

Dat. sêle

Acc. sêle

sêla

sêlena

sêlum -on

sêla

\section{Neuter.}

Bern, child; skip, ship. Themes, Berna-, skipa-.

Nom. bern, skip

Gen bern-is-es, skip -is -es

Dat. bern -a-e, skip -a-e

Acc. bern, skip bern $(a)$,

berna,

bern -um -on,

bern, skipu -o

skipa

skip -um -on

skipu -o 
56. (r.) Like êth decline-bâm, tree; bûr, villager; dêl, deal ; erm, arm; fisk, fish; hâp, heap; stef, staff; wei, way; degan, man; finger, finger.

(2.) Like sêle decline-jerde, earth ; nose, nose ; sine, nerve; klage, complaint ; spreke, speech ; tôd, time ; jeve, gift ; lemithe, laming; kêthene, announcement; redene, speech.

(3.) Neuters-bên, bone; hêr, hair; hî̀s, house; lâf, loaf; mûth, mouth; hâved, head ; rîke, kingdom ; word, word ; gers, grass ; sker, ploughshare.

57. (г.) The plural forms in -ar (-er) are the more archaic and less frequently used. There are some in -an and -en, but they are dialectic and mostly later forms, such as the Modern West Friesic presents; i.e., -an, pronounced -en; $\hat{e} t h$-an and êd-en, Hunsingo and West Frisian; Upstalbom, riuchter -en. Observe also the remarkable form (that of the English plural) riuchter-s in the Emsiger Recht. Further plurals in -an and -en, deg-an, days (also dêg-on); dîk-an, ditches; hâvding-an, chiefs ; jeld-en, mulcts-West Frisian forms.

(2.) The genitive in -is prevails in the Rüstringer Recht, that in -es in the other documents; the dative in $-i$ is peculiar to the Ruistringer, that in $-e$ to the Brokmer, and that in $-a$ to the Emsiger and Hunsingoer.

(3.) There are two forms in the nominative and accusative plural of neuter nouns; words consisting of a short syllable have, like O.-S. and A.-S., the more ancient form $u$ (Sansk., Greek, Latin, and Gothic, a), while those with a long syllable reject the termination.

(4.) With the insertion of -ar or -er the following form their plural: kind, pl. kind-er-a; (kinda, kinder, Emsiger); klâth, vestis, pl. klather-a (klathar, klâtha); horn, pl. hornar ; bon, ban, decree; pl. bonnar (bonna, bon).

(5.) A few neuters make the plural end in $-e$, weakened from $-u$, as bêken-e, beacons. One neuter has in the Rüstringer Recht -i; lith-i, limbs. Skôch, shoe, has a remarkable plural, which recalls the O.-E. shoon: nom. skôn (?), gen. skôna-Hun. Recht, Rich. 339, 13.

(6.) In the dative plural the form -on prevails in the Rüstringer Codex; the other documents (with the exception of the Brokmer, which has -um) lean to -em. 
There is no trace of themes in $-j a$, except in a few nouns exhibiting $e$ in the nominative singular, as hôdere, hat-bearer; hiskthe, family; and words derived from the Latin even drop this $e$, as altêr for altâre; but $i$ for $j$ vocalised occurs in $b \hat{\imath} t i$, bite, genitive bites; hiri, army, genitive hiris.

(7.) The masculine and neuter themes in -va (wa) drop the v altogether, e.g., sê, sea, dative and accusative $s \hat{e} ; k n \hat{\imath}$, knê, dative $k n \hat{\imath}$, $k n \hat{e}$, accusative $k n \hat{\imath}, \operatorname{kn} \hat{\imath} u$ (O.H.-G., kniwi, in composition); trê, tree, A.-S. treow.

\section{Class II. Themes in $i$.}

Masculine.

Liode, people. Theme, liodi-.

Nom.

Gen.

Dat.

Acc.
Plural.

liode

lioda

liodum

liode

Tôth, tooth. Theme, tôthi-

Nom. tôth

Gen. tôthes

Dat. tôthe

Acc. tôth têth (tôthan, Huns.)

tôtha

tôth -em -on

têth

\section{Feminine.}

Nêd, need. Theme, nêdi-

Nom. nêd

Gen. nêde

Dat. nêde

Acc. nêde nêda

nêda

nêd-im -um -on -em

nêda

59. There are but few words of this declension, which contains only masculine and feminine nouns: bende, band; dêde, deed; bôk, book; knt, cow; strête, street; wrald, world. The only masculines are Rîmere $(a)$, pilgrim to Rome; fôt, 
foot; tôth, tooth; liode, people. The original $i$ sometimes is found in the dative plural, feminine; but the forms of the declension in $-a$ have much encroached upon those of that in $-i$, as may be observed from the paradigms. The $e$ of the oblique cases has gradually been admitted into the nominative, as in dêde, deed, therefore presenting no distinction between the cases in the singular. Bôk and $k \hat{u}$ do not exhibit the umlaut as in Anglo-Saxon; except the latter in later Friesic, for which the plural ky occurs once or twice.

60. Class III. Themes in $u$.

Masculine.

(I.) - Sunu, son. Theme, sunu-.

Singular.

Nom. sunu (o)

Gen. suna

Dat. suna

Acc. sunu
Plural.

sunar (a)

suna

sunum

sunar $(a)$

\section{Neuter.}

Fia, pecus, pecunia. Theme, filu.

Nom. fia

Gen. fias

Dat. fia

Acc. fia
Wanting.

(2.) But few remnants of this declension are found. Add to the above fretho, peace; and perhaps the dative honda of hond, feminine, may be cited as a remuant of this declension.

\section{THE WEAK DECLENSION.}

61. The theme of the weak declension ends in -an. The case endings have mostly fallen away, and even the $n$ of the theme. 


\section{Masculine.}

Theme, honan-, cock.

Nom. hona
Gen. hona
Dat. hona
Acc. hona hona

honan - a (-ona)

honu $-m$

hona

\section{Feminine.}

Theme, tungan-, tongue.

Singular.

Nom. tunge

Gen. tunga

Dat. tunga

Acc. tunga

\section{Plural.}

tunga

tungan -a

tungu -m

tunga

\section{Neuter.}

Theme, âgan-, eye.

Nom. age

Gen. âga

Dat. âga
Acc. âge

âgon
(âgen -a)
agen -um, aggum
agon, âgene

Theme, âran-, ear.

Nom. are

Gen. arca

Dat. ara

Acc. âre âra

âren $-a$

aru $-m$

arca

62. The masculine and feminine nouns have all lost the $n$ of the theme, but in the neuter we observe in the nominative plural agon the ancient form, and the thematic $n$ preserved in the dative agenum. There are feminine nouns of this declension which have dropped the thematic vowel and appear with the termination $e$, as kelde, cold; hrêne, smell, \&c.

Some of the documents still exhibit in the plural the case sign $n$, as in fona, banner, accusative plural fanen; frôwe, woman, accusative plural frôun. 
63. (I.) The following nouns belong to this deciension:Masculine-boda, messenger ; frana, judge ; grêva, earl ; hêra, lord ; knapa, servant; maga, stomach; mutha, mouth of a river; neva, nepos; noma, name ; omma, spirit ; thûma, thumb ; willa, will; manniska, homo.

(2.) Feminine-forne, woman; herte, heart; lunge, lungs ; sunne, sun; svarde, skin; tâne, toe.

(3.) Neuter-age, eye ; âre, ear.

\section{Other Consonantal Themes.}

64. Themes in $r$, primitive tara, tar.

Masculine.

Feder, ${ }^{*}$ father ; brôther, brother. Singular.

Plural.

Nom. feder

Gen. feder $-(s)$

Dat. feder $-(e)$

Acc. feder

federa.

federa

federum

federa

Thus decline the feminine nouns môder, mother; swester, sister; and dôchter, daughter. Sometimes, however, they take in the genitive singular the termination $e$. Remarkable is the later form feders, sometimes occurring in the nominative plural, so similar to English fathers.

65. Themes in $n d$.

Participial themes in $n d$.

Friund.
Nom. friund
Gen. friundes
Dat. friund -e
Acc. friund

friund
friunda $-n-e$
friundum
friund

Like friund decline fîand, enemy ; mônath, mônd, month ; though the later plural nominative has strong form, mônatha -r. Wîgand, warrior, and werand, auctor, are doubtful.

* The Old Friesic has the ancient atta (Goth. atta, father), not in the sense of father, but rather in that of magistrate. 'The modern dialects, however, have it in the primitive signification; thus in Amrum, atj, Hindelopian ate; heit of the Frisians between the Fli and Lauwers. 
66. Themes ending in a guttural or dental.

$$
\text { Naht, night. }
$$

Nom. naht

Gen. nahtes

Dat. naht -e

Acc. naht

naht and nahta

* nahta

nahtum

naht and nahta

Burch, castle.

Nom. burch

Dat. burch

burga

67. Anomalous.

Mon, man.

$\quad$ Singular.
Nom. mon
Gen. monnes
Dat. mon, monne
Acc. mon

68. Defective Nouns.

Most abstract nouns, proper names, and nouns of material have no plural, as gold, selover, duged, virtue, excellence; fi $a$, pecus, pecunia ; rein, rain ; hât, hate ; wîsdôm, wisdom; hunger, hunger; slêp, sleep, rest.

\section{Proper Names.}

Proper names are declined in various ways. The native names follow the strong declension. Of foreign names, some follow their own foreign declension, and others are indeclinable.

\section{Diminutives.}

Diminutives are almost entirely wanting in Old Friesic and Anglo-Saxon, though in the latter there are geongling, youngling; rapp-incle (ráp, rope), string, and four or five others.

In the West Lauwers laws (Di fyfta doem, Richth. 420, 25) occurs a diminutive in -ke-weseken, young orphans. See also Epkema's Japickx, p. ii. of the Grammar.

Diminutives do not exist in the modern West Frisian Hindelopian dialect, which is very archaic in many respects, 
though common in the others, as beanstjes, small beans; bantsje, small band; glas-ke, little glass; bânt-je, path (bân, a road, way).

\section{SOMMARY OF THE DECLENSIONS.}

Nom. Singular.

Gen. $-e s-i s-e-a$, or same as nominative.

Dat. $-a-e-i$,

Acc. $-\alpha-e$,

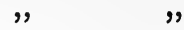

9, 99

Plural.

Nom. -ar - a -e - $u$-an -en, stem vowel changed, or same as nominative singular.

Gen. - $a$-ena -ane.

Dat. -um -on -im -em.

Acc. same as nominative.

\section{THE ADJECTIVE.}

72. There are two declensions of the adjective, the strong or indefinite declension, and the weak or definite. The latter is the declension of the adjective when preceded by the demonstrative or article, by the possessive pronouns, and by the adjective $a l$, or when the adjective is in the comparative degree.

\section{THE INDEFINITE DECLENSION.}

Gôd, good.

Singular.

Nom. gôd

Gen. gôdes

Dat. gôda $-e$

Acc. gôd-ene -ne -en

Fen.

gôde

gôdere

gôdere

gôde

NEUT.
gôd
gôdes
gôda $-e$
gôd

Plural. All Genders. gôda $-e$ gôdera gôda -e gôda -e

74. This declension closely agrees with the one of the same name in Anglo-Saxon, even to the syncopation of the vowel in the terminations ene, ere, era, \&c.; for instance, allra for allera, otthra for ôthera, \&c. 


\section{THE DEFINITE DECLENSION.}

\begin{tabular}{|c|c|c|c|}
\hline & Singular. & & Plural. \\
\hline Masc. & Fem. & Neut. & ALL GENDER \\
\hline Nom. gốda & gôde & gôde & $g \hat{o} d a$ \\
\hline Gen. gôda & $g \hat{a} d a$ & gôda & gôdena \\
\hline Dat. gôda & $g \hat{o} d a$ & $g \hat{o} d a$ & gôdum (-o \\
\hline Acc. gôoda & $g \hat{o} d a$ & gôde & $g \hat{o} d a$ \\
\hline
\end{tabular}

76. Adjectives ending in a consonant with a preceding short vowel, double the former in the inflections, as al, all, plural, alle; ful, fulle.

77. Adjectives ending in $e$ have that vowel syncopated in the inflections, as rîke, rich, accusative rîka; grêne, green, dative grêne. The $e$ is a trace of the ancient $j$ of the themes in $j a$.

78. Both participles, the past and present, are declined like adjectives of the strong and weak declension. The present shows a trace of the ancient formative $j$ before the case signs in the termination $e$ of the uninflected cases of the strong declension, as findande.

\section{COMPARISON.}

79. Comparison is effected by means of the suffixes $-i r$ and -or (weakened er) for the comparative, and -ost (-ist, -est, and -ast modifications) for the superlative.

80. Adjectives in the comparative are only inflected according to the weak declension, as hâch, high; hagera, higher; weldech, powerful, comparative weldegera. The two declensions reassert themselves in the superlative : examples of the superlative hâgost, highest; sibbest, superlative of sib, related.

81. In view of the limited vocabulary of the Old Friesic, and the necessity for the deduction of those adjectives which 
are by reason of their signification (such, for example, as gelden, golden; hêthen, heathen; jêroch, of age, \&c.) incapable of comparison, it will not appear strange that we find but few compared at all.

82. A relic of the ancient superlative in -ma may be observed in forma, first, medma, medius, which were, however, afterwards provided with an additional superlative suffix, -est, so that formest and medemest occur, the original force of the - $m a$ having been forgotten. A similar duplication is presented in the ordinals in the Emsiger and Hunsingo documents, \&c., e.g., thred-tên-de-sta, thirteenth (de-da-ta being one superlative termination, and the -sta another) ; fif-tîn-de-sta, fifteenth; ach-tên-de-sta, eighteenth ; sogen-tên-de-sta, seventeenth ; and fiower-tin-do-sta, in the Rüstringer Recht. The only relics of the comparative endings, $-r a, t a-r a$, are to be found in adverbs, prepositions, \&c.; and in oth-er, eft-er, ov-ir, und-er, \&c.

83. It is easy to decide which of the forms ir or or has been weakened into er-when that occurs-from the umlaut caused by the former in the preceding syllable, as in alt, old, comparative eldera.

84. Sometimes nothing but the consonant of the suffix remains, as in fir, far, comparative ferra; hach, comparative hâgra. Again, there is syncopation of the stem, as in harra for hâgera, best for betest, \&c., and omission of the vowel of the superlative affix, as in fir-st, middel-st.

\section{IRREGULAR AND DEFECTIVE COMPARISONS.}

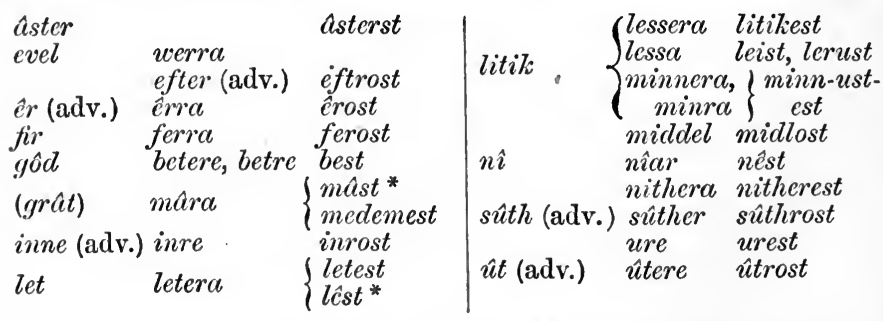

* This superlative is combined with end, end, to form an emphatic extremus, ultimus; thus, ende-lêst, ender-mêst. 


\section{COMPARISON OF ADVERBS.}

86. The comparison of adverbs is very irregular and limited.

$\begin{array}{lll}\text { fir } & \text { firor } & \text { first } \\ \text { forth } & \text { further, forther } & \\ & \text { min } & \\ & \text { mâr, mâa } & \\ \text { wel } & \text { bet } & \text { best }\end{array}$

\section{N U M E R A L S.}

\section{CARDINALS.}

I $\hat{e} n$

2 twêne

3 thrê

4 fiuwer

5 fîf

6 sex

7 sigun

8 achta

9 nigun

ro tian

$\begin{array}{ll}\text { I I } & \text { andlova, elleva } \\ \text { I } & \text { twilif } \\ \text { I3 } & \text { (thrêtine) threttene } \\ \text { I4 } & \text { fuwwertine } \\ \text { I5 } & \text { fîftine } \\ \text { I6 } & \text { sextine } \\ \text { I7 } & \text { siuguntine } \\ \text { I8 } & \text { achtatine } \\ \text { I9 niuguntine }\end{array}$

20 twintich

30 thrîtich

40 fiuwertich

50 fîftich

60 sextich

70 siuguntich

80 achtantich

90 nigontich

roo hundred

The above are the regular forms; great laxity, however, prevails in the orthography, and we sometimes find a numeral spelled in four or five different ways, all, however, easily recognisable, so that it will not be necessary to annex a list of variations.

88. A relic of hund, A.-S. hund, as in hund-seofontig, hund-eahtatig, hund-nigontig, is observable in $t$-niogentich, ninety ; $t$-achtich, eighty, (New Friesic and Dutch, tachtig).

\section{ORDINALS.}

With the exception of other, which is a comparative, and forma, having another. superlative ending, the ordinals are superlatives, having the superlative base -ta for a termination.

First, forma, êrosta

Second, ôther, ôr

Third, thredda

Fourth, (fiuwerda)

Fifth, fîfta

Sixth, sexta

Seventh, sigunda
Eighth, achtunda

Ninth, niugunda

Tenth, tianda, tegôtha

Fifteenth, fiftînda

Twentieth, twintigosta

Thirtieth, thrîtigosta

One-hundredth, hondersta 


\section{DECLENSION OF NUMERALS.}

One.

$\quad$ Masc.
Nom. ên, an
Gen. ênes, ânes
Dat. êna
Acc. ênne, ânne

MASC.

Nom. twêne

Gen.

Dat.

Acc. twêne

\begin{tabular}{|l} 
FEM. \\
ên, an \\
ênere \\
ênere \\
êne
\end{tabular}

Two.

$\quad$ Fem.
twa
twâra
twam
twa

NeUT. $\hat{e} n, a n$ ênes êna ên

(r.) The genitive of $e n$ is used adverbially to signify "once."

(2.) The weak forms of ên are êna, everywhere except in acc. neut. êne.

(3.) $\hat{E}_{n}$, with the prefix al (the $l$ being geminated before the long vowel), serves to form the adverb (as well as adjective) allêne, alone. Like ên decline nên, none. The numeral adverb for twice is twîra.

(4.) In compnunds twa alone occurs; e.g. twa and tuintech merka, two-and-twenty marks ; twâ and thrîtech scillingar, twoand-thirty shillings; twa hundred scillinga, two hundred shillings. Sometimes inflected, as in bi twâm and thrîtich merka, bi twam hundred scillingum. The conjunction sometimes loses its dental media in such collocations; as in fiuwer antwintege merka, twenty-four marks ; ên antwintich, one-and-twenty.

(5.) That the original distinctness with respect to gender in this numeral became somewhat impaired is evinced by the fact that twêne is sometimes found with a feminine noun, and twa with a masculine.

91.

Nom. thrê

Gen. thrîra

Dat. thrium, thrîm. Acc. thrê

Three.

thria

thrîra

thrium, thrîm

thria thriu

thrîra

thrium, thrîm

thriu

The numeral adverb for thrice is thrîa. 


\section{OTHER NUMERALS.}

Both.

Nom. bêthe

Gen. bêdera

Dat. bêtha, bêda, * bêdem

Acc.

bêthe
bêthe
bêtha

bêtha

bêtha

(I.) The other numerals are of common gender and uninflected, except in isolated cases.

(2.) There is a distributive form in the Emsiger Recht, tuine (Goth. tweihnai), which occurs in the phrase tuiska tuine kindem, between two children of different mothers (Ger. zweierlei Kinder).

(3.) Other has the inflection of a strong adjective, but has, on account of its signification, suffered a transposition of the strong nominal ending for the dat. pl. into the sing.; thus dat. sing. otheron, ôthrum.

(4.) Multiplicatives are formed by the addition of -fald, as in ên-fald, thrî-fald, \&c.

(5.) To supply the wanting numeral adverbs, sêth or stund is employed; thus, tian sêthen or tian stunda.

93. There is a peculiar use of sum, attached to numerals, in the genitive, in this : that it gives the sense of one's self being the third, fourth, fifth, \&c., with two, three, or four others, indicating a close companionship ; thus, twira-sum, thrîra-sum, two, three of us together. This same idiom occurs in A.-S., O.-S., and in Sanskrit. †

* When standing alone, or after the word to which it refers.

† As in "praviśatyátmanátritîyo, with himself as the third, or, with himself making the third, i.e., himself and two others. This is a remarkable compound, not unusual in Sanskrit. Compare pạndavámátri-shashțah, the Pándavas with their mother as the sixth ; i.e., five persons, or six, counting their mother (Hid. i. I, Bopp). Again, chháyádwitíyo Nalah, Nala made two by his shadow, umbrageminatus (Nala, Bopp, ch. v. 26). Also, adhite chaturo Vedán ákhyana-panchamán, he reads the four Vedas with the Ákhyánas as a fifth (Nala, vi. 9). A very similar idiom prevails in Greek, ávods being used after the ordinal numbers to show that one person, in conjunction with some others, whose number is less by one than the number mentioned, has done something; thus, $\pi \epsilon \mu \pi \tau$ os àvros, himself with four

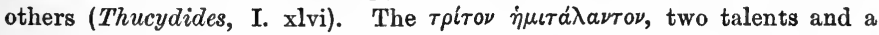

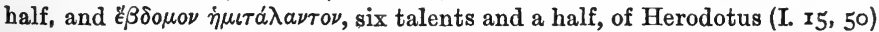
afford a further illustration of this idiom."-Sakuntala, p. 12, ed. Monier Williams, 1853. 


\section{PRONOUNS.}

Singular.

1st Person. 2d Person.

Nom. ik

Gen. mîn

Dat. $m i$

Acc. $m i$ thu

thîn

thi

$\operatorname{tn} i$

MASC.
hi, he
(sin)
him
hini-e-a

\section{Plural.}

1st Person. 2D Person.

Nom. wi
Gen. $\hat{u} s e r$
Dat. $\hat{u} s$
Acc. $\hat{u} s$

$i, g i$
iuwer*
iu, io
iu, io

3D Person.

hiu, sê

hiri

hiri

hia, sê
Neut.

hit

(sin)

him

hit

95. (I.) This dialect makes use of the demonstrative base $h i$, prim. $k i$, throughout in the third person, except in the masculine and neuter genitive singular, where it employs sîn, which is the only remnant of. the true pronoun of the third person existent. We find in the nominative plural the base $s i$ as well as $h i$. There is another pronoun of the second person side by side with thu, viz., ju, jo, gen. joen; gen. pl. joere, joewer. Also one of the third person (Mid.-Fr.) jen, he, an intruder from the Germ. (jener), or possibly a relic of the ancient demonstrative jener, Goth. jains.

(2.) The possessive pronouns are mîn, thîn, sîn (from an ancient reflexive si, sê), hiri (hire), ûse, juwe. They have strong adjective endings.

96. (I.) Very necessary to be noted is the contraction suffered by the pronoun of the third person, in this: that it exhibits a tendency to join itself, in the nominative, to the demonstrative, to other forms of itself, and in various cases and other words (following them), in a very truncated shape. Instead, however, of $h i$ the pronominal base employed by the Old-High-German is used for the expression of the nominative masculine, viz., er transposed thus -re; so

* Jemma, in later Friesic; also used in the nominative and dative. 
we quote $s \hat{a}-r e$, so he, for $s \hat{a} h i, s \hat{a}$ er, mei-re for mei er, may he, \&c. For hit simply -'t or et occurs : e.g., mei't, may it; is't for is hit, and skel't for skel hit, jev-et, if it. For hini or hine, -ne is the form employed: e.g., halde'ne for halde hine; hi'ne for hi hine; sâ nime hi'ne, so let him take him. For him only - $m$ appears : alsâ ' $m$, as to him. $E r$ occurs disjoined sometimes, as in thet er, that he. We also find jev-e for jef $h i$, and $e$ in some other cases employed for $r e$, and $r a$ for hiara.

Special attention should be paid to these forms, as they are printed without any typographical device to distinguish or call attention to them (thus haldene), and it may in some cases be difficult to recognise them.

(2.) This prevails to such an extent in Modern Friesic (and not alone in connection with pronouns, but generally) that, unprovided with a clue, one might readily find many forms undecipherable, e.g., kanstû for kanst dû ; hästune = häst dû him; häwi =häbbe wi; dô slûgzene for dô slûg djù him.

97. The same kind of contraction characterises the demonstrative thi: thus thet-et for thet (conjunction) thet; thet- $i$ for thet thi; oppa-re stêde, on (or at) the place, for oppa there stêde; umbe-ne for umbe thene; oppa-ne for oppa thene; $\hat{u t-a}$ for ut tha; with-es for with thes; and then, again, we find the latter part of the article lopped off, and generally remarkable forms appearing, as wel-eth for wel-thet, \&c. Thet appears with loss of aspiration in is-tet; and $d$ replaces the aspirate after $n$, e.g., andere, anda, \&c.

98. That there was formerly a dual in Friesic is apparent from its occurrence in modern dialects, in which it has long existed in pronouns; thus, in North Friesic-

First Person.

wát

unk

unk
Second Person.

ját junk junk 
Risum and Lindhold (Grimm, Geschichte der $d$. Spr., 976).

First Person.

Nom. wat

Gen. unker

Dat. unk

Acc. unk
Second Person.

jat

junker

junk

junk

IsLAND OF SyLt (Germaniens Volkerstimmen, I. I).

First Person.

Nom. wat, we two

Gen. unk

Dat. unk

Acc. unk
Second Person. $a t$, you two; jat, they two junk jam junk jam junk jam

The dual thus retained is a singularly archaic formationolder even in some respects than the Gothic, which has, for instance, no nominative dual second person, but which undoubtedly was jut.

\section{DEMONSTRATIVE PRONOUNS.}

(I.) First Demonstrative. The Definite Article thi. Singular.

Nom. thi

Gen. thes

Dat. tham, tha

Acc. thene

Inst.

\begin{tabular}{|l|} 
FEM. \\
thiu* \\
there \\
there \\
tha
\end{tabular}

\begin{tabular}{|l|l|} 
NeUT. & Plural. \\
thet & tha \\
thes & thera \\
tham, tha & tham, that \\
thet & tha \\
thiu &
\end{tabular}

Some of the above forms in the texts begin with a $d$.

(2.) In the modern dialects of Heligoland and West Frisia there is no distinction (as there is not in Danish or Swedish) between the masculine and feminine article.

(3.) The instrumental appears in a few adverbial phrases, as in efter thiu, thereafter; bi-thio, therefore; til thiu, in order that ; with thiu, according as.

* Theo, thiu, thio, and thy occur for this in A.-S. (especially in Northumbrian) in some cases instead of seo. See the glossarial remarks of Sir F. Madden to Layamon's Brut, vol. iii. p. 44I, and March, Anglo-Saxon Grammar, p. 6g. 
100. Second Demonstrative, this.

\begin{tabular}{|c|c|c|c|}
\hline \multicolumn{3}{|c|}{ Singular. } & Plural. \\
\hline Masc. & FEM. & NeUt. & \\
\hline Nom. this (dis) & thius (dius) & thit (dit), this & thisse, thesse \\
\hline Gen. thisses & thisse, disse & thisses, disses & $\left\{\begin{array}{l}(\text { thessera }) \text { dis- } \\
\text { ser, desser }\end{array}\right.$ \\
\hline $\begin{array}{l}\text { Dat. thisse, thessa } \\
\text { Acc. (thisne, thesne) }\end{array}$ & $\begin{array}{l}\text { disse } \\
\text { thisse }\end{array}$ & $\begin{array}{l}\text { thisse } \\
\text { thit, dit }\end{array}$ & $\begin{array}{l}\text { thisse, thesse } \\
\text { thisse, desse }\end{array}$ \\
\hline
\end{tabular}

\section{INTERROGATIVE PRONOUNS.}

\author{
MASC. \\ Nom. hwa, who \\ Gen. hwammes \\ Dat. hwam \\ Acc. hwane, hwene
}

Singular.

(I.) The genitive of this pronoun is constructed on the dative form.

(2.) No interrogative was developed for the feminine.

(3.) Hwelîk (hwêk) is declined like the adjective.

\section{RELATIVE PRONOUNS.}

102. The particle ther and the demonstrative perform the functions of the relative pronoun. Care should be taken to discriminate the particle ther from the adverb thêr (ibi). Both the adverb and the particle are subject to the contraction referred to in Sections 96 and 97, loss of aspiration, \&c., as in thet-ter, Germ. das was, môt-er, \&c. Sometimes the abbreviated form -re or -ere occurs for the adverb thêr, which is frequently identical in its use with the English pronominal adverb there, employed to introduce propositions ; e.g., skelenere wesa, shall there be; hwet-sât-re, whatever there, \&c.

\section{INDEFINITE PRONOUNS.}

103. Sum, pl. summe, sumlîke, nên, $m a^{*}=$ French on-ma sometimes having, before a word beginning with a vowel, an $r$ appended to it, in order to avoid a hiatus, as in hwers $a$ ma-r

* $M a$ once has a verb agreeing with it in the plural; als ma schildich sint, which has reference to its really plural signification of pesple. 
ênne thiaf fêth, whoever catches a thief; hweder, uter; hwa-sâ,

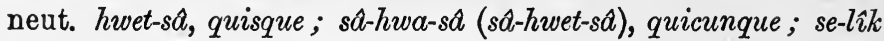
= Goth. swa-leiks-such ; hwelîk, hwêk, each; el-lîk (from a-ge$l \hat{\imath} k$, O.-H.-G. ëo-ga-likh) shortened to -elk, êk, is very frequently (in the latter form) appended to a noun, as in aller-êk, alr-êk, alra êk; allera-jerd-îk for allera jerda êk; aller-monn-îk for allera monna êk, aller-lîk, unusquisque; ênich, ullus.

\section{THE VER B.}

\section{Voices.}

104. There are two voices in the Old Friesic, the active and the passive. The only representative of the passive is a participle. Verbs are conjugated in the passive voice by the aid of auxiliaries.

\section{Moods.}

105. There are three moods, the indicative, the subjunctive, and imperative. The infinitive and gerund are nouns, and the participles are adjectives.

\section{Tenses.}

106. There are but two tenses, the present and preterit; but the future, perfect, and pluperfect are supplied by the assistance of auxiliaries.

\section{Conjugations.}

107. Verbs are conjugated in two ways, viz., according to the strong and weak conjugations.

Strong verbs are such as express past time by a change of the root vowel.

Weak verbs express past time by composition. The preterit of weak verbs is that of the verb to do, joined to the verbal theme.

\section{AUXILIARY VERBS.}

$W e s a$, to be.

I N D I C A T I V E.

Present Tense.
I. bem (ben)
2. (bist)
3. is 
Preterit.

I. was

2. wêre

3. was

wêron

wêron

wêron

S U B J U N C T I V E.

Present.

$s \hat{e}$
$s \hat{e}$
$s \hat{e}$

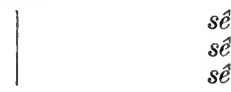

Preterit.

wêre

wêre

wêre

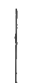

wêre

wêre

wêre

I M P E R A T I V E.

2. wese

wesath (wesset)

I N F I N I T I V E.

wesa

P A R T I C I P L.

(e) wesen

GER U N D.

tô wesande.

109. W E R THA.

Present Indicative, Singular werth, plural werthat $(h)$.

Preterit "

Present Subjunctive,

Preterit

IMPERATIVE,

GERUND,

Participle Present,
" warth, ", wurdon.

werthe.

wurde.

Singular werthe.

Plural werthat. tô werdane. werdand. wurthen. 


\section{FIRST CONJUGATION.}

\section{Strong Verbs.}

110. Verbs of Classes $\mathrm{I}, 2,3$, and 4 ( $\mathrm{I}$ and 2) present evidence, in the ablaut, of original reduplication, which, however, has only been preserved in Gothic. Upon Friesic its only impress is its influence exhibited upon the vowel system of the verbs.

For the formation of the present theme, to the root $-e=-i$, which supplanted an earlier $-a$, is added, thus, find-e. To a few -ja is added, as in lidzja, swerja, bidja, bidda, sitta $=$ sitja, and in two or three an $n$ is inserted in the root before the final consonant: as in sto-n-da, root sta; gu-n-ga, root $g a$; bre-n-ga, root brag; tha-n-ka or the-n-zja, root thak, dak; thi-n$s z j a$, root thuk, $d u k$.

Strong verbs are ranged in ten classes, which are as follows: * -

\begin{tabular}{|c|c|c|c|c|c|}
\hline & RADICAL. & Present. & $\begin{array}{l}\text { Preterit } \\
\text { Sing. }\end{array}$ & $\begin{array}{l}\text { Preterit } \\
\text { Plur. }\end{array}$ & $\begin{array}{l}\text { Preterit } \\
\text { Part. }\end{array}$ \\
\hline $\begin{array}{l}\text { Class I. } \\
\text { Grimm iv., v., vi. }\end{array}$ & $a, \hat{e}$ & $\hat{e}$ & $\hat{\imath}, \hat{e}$ & $\hat{\imath}, \hat{e}$ & $\hat{e}$ \\
\hline $\begin{array}{l}\text { Class } 2 . \\
\text { Grimm i. }\end{array}$ & $a$ & $a$ & $\hat{\imath}, \hat{e}$ & $\hat{\imath}, \hat{e}$ & $\alpha$ \\
\hline $\begin{array}{l}\text { Class 3. } \\
\text { Grimm. ii. }\end{array}$ & $a i(i)$ & $\hat{e}$ & $\hat{\imath}, \hat{e}$ & $\hat{\imath}, \hat{e}$ & $\hat{e}$ \\
\hline $\begin{array}{l}\text { CLASS } 4 \text { (I): } \\
\text { Grimm iii. }\end{array}$ & $a u(u)$ & $a$ & $\hat{\imath}, i o$ & $i, i o$ & $\hat{a}, \hat{e}$ \\
\hline Class 4 (2). & $\hat{o}(\alpha)$ & $\hat{o}, \hat{e}$ & $\hat{\imath}$, io & $\hat{\imath}$, io & $\hat{\sigma}, \hat{e}$ \\
\hline $\begin{array}{l}\text { CLASS } 5 \cdot \\
\text { Grimm viii. }\end{array}$ & $i$ & $\hat{\imath}$ & $\hat{e}$ & $i$ & $i$ \\
\hline $\begin{array}{l}\text { CLASS } 6 . \\
\text { Grimm ix. }\end{array}$ & $u$ & $i u, i \alpha, \hat{u}$ & $a$ & $e$ & $e$ \\
\hline $\begin{array}{l}\text { CLass } 7 . \\
\text { Grimm vii. }\end{array}$ & $a$ & $a, e$ & $\hat{o}$ & $\hat{0}$ & $a, e$ \\
\hline $\begin{array}{l}\text { Class } 8 . \\
\text { Grimm x. }\end{array}$ & $a$ & $i, e$ & $a, e$ & $a, \hat{e}$ & $i, e$ \\
\hline $\begin{array}{l}\text { Cuass } 9 . \\
\text { Grimm xi. }\end{array}$ & $\alpha$ & $i, e$ & $a, e, \hat{e}$ & $\hat{a}, \hat{e}$ & $i, e$ \\
\hline $\begin{array}{l}\text { Class ro. } \\
\text { Grimm xii. }\end{array}$ & $a$ & $i, e$ & $a$ & $u$ & $u$ \\
\hline
\end{tabular}

*Helfenstein's Compar. Gram. of the Teutonic Languages, p. 4Ix ff. 


\section{Verbs to illustrate the classes.}

Class I, slêpa, rêda, lêta, wêpa.

" 2, halda, walda, banna (bonna).

" 3, hêta, skêtha.

" 4 (I), hlapa, stêta; Goth. stautan.

" 4 (2), hrôpa, * floka.

" 5, grîpa, drîva, snîtha, hnîga, stîga.

" $\quad$ 6, diupa, kriapa, niata, skiata, slûta, biada, kiasa, liasa, liaka.

" 7, fara, skapa, waxa, draga, slaga.

, 8 ,

", 9, jeva, bira, stela, nima, wesa, breka, spreka.

" Iо, hilpa, binda, finda, winna, berna, werpa, wertha.

\section{PARADIGMS.}

Finda, to find; kiasa, to choose.

Pres. Infin. Pret. Indic. Pret. Plur. Pass. Part. finda, kiasa. fand, kas. fundon, keron. funden, keren.

\section{ACTIVE VOICE.}

\section{N D I C A T I V E MOOD.}

\section{Present Tense.}

Singular.

Ik finde, kiase, I find, choose

Thu findest, kiosest, thou findest, choosest

Hi findeth, kioseth, he finds, chooses
Plural.

Wi findath, kiasath, we find, choose I findath, kiasath, you find, choose Hia findath, kiasath, they find, choose

Preterit.

Fand, kâs, I found, chose Fundest, kerest Fand, kâs

Skil finda, kiasa Skalt finda, kiasa Skil finda, kiasa
Fundon, keron, we found, chose Fundon, keron

Fundon, keron

\section{Future.}

I shall find, choose.

$$
\mid \begin{aligned}
& \text { Skilu }(n) \text { finda, kiasa } \\
& \text { Skilu }(n) \text { finda, kiasa } \\
& \text { Skilun finda, kiasa }
\end{aligned}
$$

\section{Perfect.}

I have found, chosen.

Hebbe funden, keren

Hast funden, keren

Hêth funden, keren
Hebbath funden, keren

Hebbath funden, keren

Hebbath funden, keren

This verb also has a weak preterit, $h r o ̂ p-t e$. 


\section{Pluperfect.}

I had found, chosen.

Hede funden, keren

Hede funden, keren

Hedon funden, keren Hedon funden, keren Hedon funden, keren

\section{S U B JUNCTIVE MOOD.}

Present Tense.

(If) I find, choose.

Singular.

Finde, kiase

Finde, kiase

Finde, kiase
Plural. Finde, kiase Finde, kiase Finde, kiase
Preterit.

(If) I found, chose.

Singular. Funde, kere Funde, kere Funde, kere

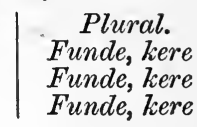

Perfect.

(If) I have found, chosen.

Hebbe funden, keren Hebbe funden, keren Hebbe funden, keren

\begin{abstract}
Plural. Hebbe funden, keren Hebbe funden, keren Hebbe funden, keren
\end{abstract}

\section{Pluperfect.}

(If) I had found, chosen.

Singular.

Hede funden, keren Hede funden, keren Hede funden, keren

Plural.
Hede funden, keren
Hede funden, keren
Hede funden, keren

I M P ERATIVE MOOD.

Find, choose.

Find, kios (2d person)

| Findath, kiasath

I N F I N I T I V E.

To find, choose.

Finda, kiasa

PARTICIPLE.

Present.

Finding, choosing.

Findand, kiasand

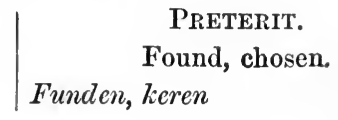

G E R U N D.

'To' find, choose.

To findande, kiasande. 


\section{PASSIVE VOICE.}

\section{IN DICATIVE MOOD. \\ Present Tense.}

\begin{tabular}{|c|c|}
\hline $\begin{array}{l}\text { elar. } \\
\text { den, keren, I am }\end{array}$ & $\begin{array}{c}\text { Plural. } \\
\text { funden, keren }\end{array}$ \\
\hline ,keren, thou & \\
\hline ieren, & Hia \\
\hline
\end{tabular}

\section{Preterit.}

I was found, chosen.

Was funden, keren

Wêre funden, keren

Was funden, keren

\section{Wêron funden, keren \\ Wêron funden, keren \\ Wêron funden, keren}

\section{Future.}

I shall be found, chosen.

Singular.

Skil wesa funden, keren

Skalt wesa funden, keren

Skil wesa funden, keren
Plural.

Skilu(n) wesa funden, keren'

Skilu(n) wesa funden, keren

Skilun wesa funden, keren

\section{Perfect.}

I have been found, chosen.

Bem wurthen funden, keren, \&c. I Send wurthen funden, keren, \&c.

\section{Pluperfect.}

I had been found, chosen.

Was wurthen funden, keren, \&c.

\section{SUBJUNCTIVE MOOD.}

Present Tense.

(If) I be found, chosen.

Sê funden, keren Sê funden, keren Sê funden, keren

Wêre funden, keren Wêre funden, keren Wêre funden, keren
Sê funden, keren

Sê funden, keren

Sêfunden, keren

Preterit.

(If) I were found, chosen.

Wêre funden, keren

Wêre funden, keren

Wêrefunden, keren । 
I I P E R A T I E MOOD.

Be found, chosen.

Wese funden, keren (2d person) I Wesath funden, keren

$$
\begin{aligned}
& \text { I N F I N I T I V E. } \\
& \text { To be found, chosen. } \\
& \text { Wesa funden, keren } \\
& \text { P A R T I C I P L E. } \\
& \text { Found, chosen. } \\
& \text { Funden, keren }
\end{aligned}
$$

113. Contracted forms of wes $\alpha$ with the negative : $n \hat{\imath} s$, is not ; $n \hat{a} s$, was not; nêre, were not (subj.)

114. A future perfect tense may be formed by means of skil and hebba; thus : Ik skil hebba funden, I shall have found.

\section{INTRANSITIVE FORM OF THE VERB.}

$$
\text { I N D I C A T I E MOOD. }
$$

\section{Preterit.}

Singular.

Ik bem kemen, I have (am) come Thu (bist) kemen, thou hast come $H i$ is kemen, he has come
Plural. Send kemen Send kemen Send kemen

Pluperfect.

Was kemen, had come, \&c.

S UBJUNCTIVE MOOD.

Preterit.

Ik sê kemen, that I have come.

\section{REMARKS ON THE PARADIGMS.}

No dental but $t$ can remain before the $s t$ of the second person singular : $x s t$ becomes $x t$; th in the third person is contracted with a preceding $d$ into $t$, as in fint, halt; so also 
with $t$ preceding: with a preceding th into th; with $s$ or $s t$ into st; with $x$ to $x t$. $i$ for $e$ occurs in the second and third persons singular: ist and ith. There is quite a manifest inclination in the th to lose its aspiration; sometimes it is dropped altogether, as bieda for biadat $(h)$.

117. There is but little evidence of the employment of the umlaut in the verbal inflections. Rhotacism has been adopted, especially in Classes 5 and 6, as kass, plural keron; was, wêron, \&c.

118. Class 9 may be considered as identical with Class 8 , because the preterit participle has in both the weakened radical $\ddot{e}$; iu in Class 6 is condensed into $\hat{\imath}$, as in sluta, $l \hat{\imath} k a$.

119. The subjunctive in both present and preterit has suffered apocope of the $n$, and ends regularly in -e.

120. The so-called gerund is merely an inflected form of the infinitive-a verbal noun.

121. The verb meaning to hang has four stems, hang, honga, hu, huang. $F \hat{a}$, to take, presents the two stems fanga and $f a h$.

122. The following have one or more weak forms, principally in the pret. participle : berna, bonna, kerva, riva, skêtha, stêta, strîda.

123. Verbs like flîa, to fly ; sîu, to see; tîa, to draw ; lîa, to loan ;

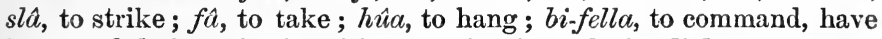
lost an $h$ before the infinitive termination: O.-S. fiohan, gi-sehan, tiohan, O.-H.-G. lîhan, O.-S. slahan, fähan, Goth. hahan, O.-S. bifelhan.

124. The dental is frequently omitted from the present participle, as in drîwen for drîwend, dregan, libban, \&c.

125. In such forms as onsittane and lidsane the final vowel is a relic of the ancient $-j a$. The present part. often has this conclusion, causing it to appear as -ande. 


\section{PERIPHRASTICAL CONDITIONAL FORM OF THE VERB.}

\section{(Verba Preterito-Presentia.)}

The proeterito-praesentia are a number of ablaut verbs which no longer exhibit a present form, but use the preterit form in a present sense, and for the expression of past time take to themselves the endings of weak verbs.

\begin{tabular}{|c|c|c|c|c|}
\hline $\begin{array}{l}\text { PRES. SiNG. } \\
\text { kan, } \\
\text { thurf, } \\
\text { dur, thur, } \\
\text { skil, } \\
\text { mei, mî, } \\
\hat{a} c h, \\
\text { wêt, wît, } \\
\text { (ducht), } \\
\text { môt, }\end{array}$ & $\begin{array}{l}\text { PRES. PLUR. } \\
\text { kunnon, } \\
\text { thurvon, } \\
\text { thuron, } \\
\text { skilu }(n), \\
\text { mugu }(n), \\
\text { ágon, } \\
\\
\text { môton, }\end{array}$ & $\begin{array}{l}\text { Pret. } \\
\text { kunda, } \\
\text { thorste, } \\
\text { skoldi(e), } \\
\text { machte, } \\
\text { achte, }\end{array}$ & $\begin{array}{l}\text { INFIN. } \\
\text { kunna, } \\
\text { thurva, } \\
\text { thura, } \\
\text { skila, } \\
\text { (mega), } \\
\text { aga, hâga, } \\
\text { wita, } \\
\text { duga, } \\
\text { môta, }\end{array}$ & $\begin{array}{l}\text { can. } \\
\text { need to. } \\
\text { need to. } \\
\text { shall. } \\
\text { may. } \\
\text { have to. } \\
\text { know how to. } \\
\text { able to. } \\
\text { must. }\end{array}$ \\
\hline
\end{tabular}

They are used with the infinitives of verbs as auxiliaries, as mei finda, may find; môt kuma, must come. To form the passive, insert between the auxiliary and participle wesa or wertha; thus: kan wesa funden, can be found.

127. Bi-jenna, one of the verbs following the analogy of the proeterito-prcesentia, has, in addition to the regular preterit, also bigunde, bigonste; the others are werka, which has a preterit written by metathesis wrochte; brenga, brensza, bring, brochte; thanka, thenszja, think, thochte; and wille, wilt, wille, plural willath, preterit welde, wolde.

\section{SECOND CONJUGATION.}

\section{WEAK VERBS.}

For the formation of the infinitive, -ja, for primitive -aya or $-\hat{o}$ (sometimes represented by $-a$ ) is added to the root.

Nera, theme ner-ja, to preserve ; sêka, to seek; salvja, to save. 


\section{Preterit Indicative.}

Nerede, sôchte, salvade

| Neredon, sôchton, salvadon

\section{Participles.}

$\begin{array}{lll}\text { Present, nerand, } & \text { sêkand, salvjand. } \\ \text { Preterit, nerid, } & \text { sôcht, } & \text { salvad. }\end{array}$

I N D I CA T I V E MO O D.

Present Tense.

Singular.
Nere, sêke, salvje

Nerist, nerst, sêkist, sêkst, salvast Nereth, sêkth, salvath
Plural.

Nerath, sêkath, salvjath

Nerath, sêkath, salvjath

Nerath, sêkath, salvjath

\section{PReterit.}

Nerede, nerde, sôchte, salvade

Neredest, sôchtest, salvadest

Nerede, sôchte, salvade

Ik skal nera, sêka, salvja

Thu skalt nera, sêka, salvja

Hi skil nera, sêka, salvja
Neredon, sôchton, salvadon Neredon, sôchton, salvadon

Neredon, sôchton, salvadon

\section{Future.}

Li skilu(n) nera, sêka, salvja I skilu(n) nera, sêka, salvja Hia skilu(n) nera, sêka, salvja

\section{Perfect.}

Ik hebbe nerid, sôcht, salvad Thu hâst nerid, sôcht, salvad Hi hêth nerid, sôcht, salvad

Wi hebbath nerid, sôcht, salvaul I hebbath nerid, sôcht, salvad Hia hebbath nerid, sôcht, salvad

\section{Pluperfect.}

Ik hede nerid, sôcht, salvad

Hi hede nerid, sôcht, salvad

Wi hedon nerid, sôcht, salvad I hedon nerid, sôcht, salvad Hia hedon nerid, sôcht, salvad

\section{SUBJUNCTIVE MOOD.}

Present.

Neri (e), sêki (e), salvje Neri, sêki, salvje

Neri (e), sêki (e), salvje

Nerede, sôchte, salvade Nerede, sôchte, salvade Nerede, sôchte, salvade

Hebbe nerid, sôcht, salvad Hebbe nerid, sôcht, salvad Hebbe nerid, sôcht, salvad
Neri (e), sêki (e), salvje

Neri (e), sêki (e), salvje

Neri (e), sêki (e), salvje

\section{Preterit.}

Nerde, sôchte, salvade Nerde, sôchte, salvade Nerde, sôchte, salvade

\section{Perfect.}

Hebbe nerid, sôcht, salvad Hebbe nerid, sôcht, salvad Hebbe nerid, sôcht, salvad 
Hede nerid, sôcht, salvad Hede nerid, sôcht, salvad Hede nerid, sôcht, salvad

\section{Pluperfect.}

\section{M P E R A I V E M O O D.}

Nere, sêce, salva (2d person)

| Nerath, sêcath, salvjath

I N F I N I T I V E.

Nera, sêka, salvja.

Present Participle, nerand, sêkand, salvjand.

PRETERIT , nerid, sôcht, salvad

GERUND, $\quad$ to nerande, sêkande, salvjande.

129. The following are the most important weak verbs:-

Wera, to defend; era, to plough ; bera, to behoove, to become ; lema, to weaken; nera, to save; sella, to sell ; setta, to set; strekka, to stretch ; tella, to number; segga, sedza, to say; spera, to investigate; capja, to buy; makja, to make; halja, to fetch; nomja, to name; ravja, to rob; endgja, to end; folgja, to follow; askja, to ask ; klagja, to complain, accuse ; radja, to speak ; skathja, skathigja, to damage ; wardja, to ward; hlaka, to laugh ; gâdurja, to gather; spera, to touch, reach ; lêda, to lead; dêma, to judge ; fêra, to lead, bring; bêta, to compensate; sêka, to seek; dêla, to divide; swera, to swear ; timbria, to build ; ondwardja, to answer; rêka, to deliver to ; hêra, to hear; slêpa, to sleep; hebba, to have; riuchta, to judge; libba, to live; thanka, to think; êrja, to honour.

\section{REMARKS ON THE WEAK CONJUGATION.}

Two forms of verbs are exhibited, viz., those having a short or long radical, as in O.-S. and A.-S.

The preterit suffix is $-d e$, which is added to the root. Short verbs may-though they seldom employ it-add the preterit suffix by means of the connective $e$ (for $i$ from $j a$ ). The Old Saxon preterit termination $-d a$, connecting vowels $i$ and $o$, appears in Friesic as -de, connecting vowels $e$ and $a$; O.-S. nerida, skawôde; Fries. nerede, salvade.

131. Verbs with organic gemination add the suffix without connecting vowel, and also quite a number of short verbs which, by means of inorganic gemination, have become long, as sella = selja, setta, tella, segga, \&c. 
132. After long roots the stem -e is syncopated, as in dêla, to distribute, preterit dêlde.

133. After $f, h, k, p, s$ (generally), $t$, and $x, d$ is assimilated or becomes surd $(-t)$, so that the suffix appears as $-t e$. The mute $k$ becomes $c h$ before $t$, as in sêka, preterit sôchte.

134. Stems having a final $k$ or its gemination afford the only examples of Rückumlaut: $e$ returns to $a$, and $\hat{e}$ to $\hat{o}$, as in sêka, sôchte; thekka, thachte.

135. The preterit participle ends in -id and -ed in verbs with short radical, and in $d$ or $t$ accordingly as the preterit suffix appears as -de or -te: as nera, nerid; wîsa, wîsde, wîsd; achta, achte, acht; sterva, sterft.

136. Verbs which in the present tense exhibit a $j$ are often further lengthened to igja, egja, gja: as endja, to end, endigja, endgja; stedja, stedigja, stedgja; skathja, to injure, skathigja, $\& c$; and we find that sometimes the first portion, $=i g$, of this suffix is mistaken for part of the root, and consequently exhibited in the formation of the preterit: as in nêdigja, preterit nêdigade, participle, nêdgad. a regularly replaces the thematic $\hat{o}$ of the Goth. : salbôda, Fries. salvade.

137. Of libba, to live, there is another form, levja or livja; 3d pers. sing. levath or livath, pret. livade; the pres. plur. is libbath, subj. libbe, pret. lifde.

138. Variations in the final vowel of the subj. pres. $-i$, as in wiri, lemi; -a, as in mêta, bêta, leva, \&c.; -je, as in thenzje, ledzje, scenzje; and disappearance of the vowel sometimes before $-m a$, as in urdêl-ma. So, generally, the final vowel drops out of many other verbal forms.

Anomalous Verbs (Verbs without Connecting Vowel).

139. The following verbs are anomalous:-rst person

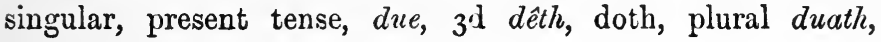


subjunctive due, preterit indicative dêde, plural dêdon, preterit participle dên, dân; gâth, geith, goes, preterit participle gên : these are the only forms of this root, all the others being supplied by gunga, preterit gêng, gengon, preterit participle gangen, gengen, gendzen.

Of the root $s t \hat{a}$ (Str. v.) we only meet with the infinitive and third singular,present indicative stêt ; everywhere else stonda, stôd, stôdon, preterit participle, stenden, stinsen.

\section{COMPOSITION.}

140. There is a great abundance of compound words in Friesic.

Nouns frequently appear unchanged in composition: e.g., stêr-hus, stone-house; the first member of the compound is sometimes in the genitive, as sunna-skin, sunshine.* Some nouns ending in $e$ cast that vowel away before the last member of the compound : e.g., irth-fal, earth-fall, felling to the ground, for irthe-fal.

141. Verbs are freely compounded with adverbs and prepositions : up-stonda, to arise; of-gunga, to go away; forthfara, to fare forth, \&c.

(a.) The prefixed preposition or adverb may occasionally, as in German, be separated from the verb whose meaning it modifies, and appear later on in the sentence: as in sprec-ma thene rêdjera on, if one appeal to the judge, \&c. And some prefixes have in course of time become so thoroughly incorporated with the verb, that the perception of their original signification has been lost, and the primary sense of the prefix is expressed by another, giving rise to apparent tautology.

142. An adjective is usually compounded with a noun without any change, as ful-brôther, half-brôther, \&c.

143. Some particles change their meaning in composition, as for, to, te, and under.

* In the compound word for Saturday, which answers to German Sonnabend, there is syncopation of the stem in both members; thus, Sniond for Sonna-âvend, Snaind, Sniun (parallel forms Snêvend, Snivend). 
To has the sense of violence involved in it sometimes under such circumstances, though it is really not the preposition; it is a prefix signifying separation, destruction-originally te. Examples : to-drîva, to tear apart ; to-dêla, separate ; for-stonda (Germ. verstehen), to understand; for-sitta, to lose, neglect; under-stonda, to understand.

The particle ur corresponds to the German ver: urbarna (Germ. verbrennen), to burn up. It is liable to be confounded with ur, over.

144. The first word in a compound, as a rule, serves to define and qualify the second; the latter is generally the more important, and gives the gender to the compound.

\section{PREFIXES.}

The following are the prefixes most frequently used:-

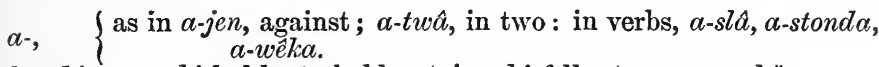
$b e-, b i-, \quad, \quad b i-h a l d a$, to hold, retain ; bi-fella, to command.* forth-, , forth-branga, to bring forward ; forth-fara, to proceed. ful-, ,, ful-branga, to complete.

in-, , in-branga, to bring in ; in-kuma, to come in.

mis-, ,, mis-dêde, misdeed ; mis-lîk, unlike.

of-, , , of-snitha, to cut off; of-sla, to strike off.

on-, , on-bijenna, to begin.

ond-, ", ond-wardja, to answer ; ond-lete (Germ. antlitz), face.

$\left.\begin{array}{l}\text { onder-, } \\ \text { under-, }\end{array}\right\}$, under-standa, understand.

to-, ,, to-bera, adferre: to-breka, to rend.

thruch-, ", $\begin{gathered}\text { thruch-skina, shine through; thruch-hawa, to hew } \\ \text { through. }\end{gathered}$ umbe-, ,, umbe-kuma, to arrive.

und-, , und-swera, to swear free.

un-, ,, un-skeldich, innocent; un-dôm, wrong.

up-, ,, up-stonda, to arise ; up-riucht, upright.

ur-, for-, ,, ur-dêma, to coudemn ; for-derva, to destroy.

$\hat{u} t$-, ,, $\hat{u}$-gunga, to go out; $\hat{u} t$-driva, to drive out.

with-(e)ir.,", wither-jeva, to give back; with-stonda, to withstand.

* There is much of a middle sense in verbs combined with the prefix $b i$ - in the Germanic languages. In fact, they indicate the same very frequently by the addition of the reflexive pronoun, as in English, to bethink one's self, to legrime one's self, \&c. 


\section{SUFFIXES.}

The following denote personal agents :-

$-a$,
$-a n d$,
$-e n$,
$e r-e$,
$-i n g$,

bon- $a$, murderer ; aseg- $\alpha$, judge.

a participial ending, fiand, enemy.

$\{$ drocht-en, a lord. This suffix also indicates things: $\{$ têk-en, token; bêk-en, beacon.

scrîv-ere, writer, scribe ; prêst-er, priest.

- ing,

$\left\{\begin{array}{c}\text { hus-ing, paterfamilias; kin-ing, king; îthel-ing, noble- } \\ \text { man. }\end{array}\right.$

147. (г.) The following denote abstract notions, circumstances, or things :-

-ath, môn-ath, month ; thing-ath, assembly.

-dôm, frî-dôm, freedom; kersten-dôm, Christendom.

-êde, -hed, $\left\{\begin{array}{c}\text { (A.S. -had, Germ. -heit) kersten-êde, Christendom; } \\ \text { frî̀-hêd, freedom. }\end{array}\right.$ -er, fing-er, finger.

-ethe, -the thiuv-ethe, theft; lemi-the, injury.

-elsa wlem-elsa, a wound.

inge, -unge, $\left\{\begin{array}{c}\text { blend-ing, blinding; bûv-unge, building, dwelling. } \\ \text { (This is a participial form). }\end{array}\right.$

-ma, set-ma, order; brek-ma, fine.

-nese, heft-nese, prison; urdem-nese, condemnation.

-rîke, himul-rîke, heaven; kining-rîke, kingdom.

-skip, her-skip, army ; rêd-skip, advice.

(2.) -dôm, -skip, -êde, -hêd, and -rîke were originally independent words:-skip, being from the same root as skeppa, to create, form, make, had the original signification of shape, condition. Dôm is cognate with Sanskrit dhâman ( $\operatorname{root} d$ dha, ponere, constituere), dignity, heroism, \&c. -hêd, -êde, is a noun from the theme hiv-, signifying to form, create. Rike occurs separately in the form $r \hat{\imath} k$.

\section{8. (I.) ADJECTIVE ENDINGS.}

$-d a,-t a, \quad$ forming the ordinals.

-e, bôs-e, bad; diur-e, dear.

-en, stên-en, of stone; kerst-en, Christian.

-er,-ern, sûth-er, sûth-ern, southern.

-fald, thrîfald, threefold.

-ich, blod-ich, bloody ; skeld-ich, guilty.

-isk, -esk, himul-isk, heavenly ; wrald-esk, worldly.

-las, hus-las, houseless, homeless.

-likk, jêst-lîk, ghostly, spiritual ; god-lîk, godly.

-och hêr-och, obedient.

-sum, hâr-sum, submissive.

(2.) -las is preserved as an independent word, with the sense of loose, freed from, without. 


\section{FORMATION OF THE ADVERB.}

(I.) The genitive of a noun is frequently employed as an adverb : e.g., nachtes, at night. $-e$ is the ordinary ending to convert an adjective into an adverb, as jerne, willingly ; riuchte, rectê ; godlîke, in a godly manner; $\hat{\imath} d l e$, idly.

(2.) Adverbial expressions are frequently met with; they are readily formed, and employed to an indefinite extent.

(3.) Adverbs of place or direction have endings as follows:-

$-\alpha$, from a place, hwan- $\alpha$, whence.

.$d$, to a place, thar-d, thither.

-r, hwêr, where ; hîr, here.

$-e, \quad \hat{u} t-e$, without; inn-e, within.

-er, Ast-er, eastward ; west-er, westward.

-wirth (A.S. weard); sûd.wirth, southwards. 


\section{$P A R T I I I$.}

\section{SYNTAX.}

\section{GENERAL PRINCIPLES.}

150. Friesic syntax is much like that of the Anglo-Saxon, though it does not so much resemble Latin syntax as the Anglo-Saxon does. It leans more to the German model than the latter.

The fundamental principles of all syntax we must suppose to be understood, such as, for instance, that nouns in the plural require the verb to agree with them in the plural; that an adjective must agree with its noun in gender, number, and case, \&c.

151. Adjectives, however, and participles in the predicate are uninflected, retaining the form of the nominative singular masculine, e.g., tha rêdjeva ther thenne weldech send, the judges who then are in power; hwersâ him sine clâthar wet werthat, whenever his clothes may be wet upon him.

152. The proper place for a verb in a sentence or clause is at the end the auxiliary, however, following the principal verb : as, sâ hwersâ ên mon dâd eslein werth, whenever a man shall be slain; hwenne tha wed elast werthat the thêr on ebreken send, until the penalties be paid that thereto attach.

This rule, however, is subject to numerous exceptions.

153. The subject generally precedes the verb, though, 
for the sake of emphasis, and sometimes, undoubtedly, for euphony's sake, it follows the verb: thus, thâ festade Moyses, then fasted Moses; thit riucht skrêf God selva ûse hêra, this law God Himself, our Lord, enacted. There is no strict necessity in Friesic for any precise collocation of the words in a sentence, for the inflections are an infallible guide to the sense, as in German, Latin, Icelandic, and other highly-inflected languages.

\section{OF NOUNS.}

154. Nouns of time, in answer to the question "howilong?" are put in the accusative: thet tilath $m a$ thriu jêr, that shall be tilled for three years; jêr and $d \hat{\imath}$, for a year and a day. In answer to the question "when?" and where we in English say per (per annum, per month, per day, \&c.), the noun is put in the genitive: thes selva dîs, the same day; liachtes deis, in broad daylight; thiu môder thiu mey nima fon hire unjêrige bern thes jêres fiff scillingar, the mother may take for her minor child five shillings per year.

155. A preposition with the dative is also frequently used to answer the question "when?" as, binna xiv jêrum, within fourteen years; $b \hat{\imath}$ skînandere sunna, in the broad sunlight.

156. The dative expresses the indirect object, the agent, and manner and means. When a noun defines an adjective

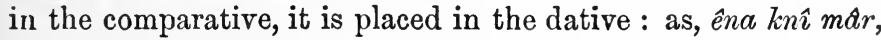
one grade more nearly related; in defining a superlative it is put in the genitive, as, alra nêst, the nearest of all. A preposition is most usually found with a dative of manner and means, and with a dative of the agent.

157. The dative expresses the object of interest, advantage or disadvantage, for whom or which something is, is done, or is to be done, as in hiri twintich merka tô bôte, for her (shall be) a compensation of twenty marks; sh-hwet-sâa hire e-dên is, whatever be done to (or for) her; hire ên unde dên, (if) she be wounded (lit. if to her a wounding be done). 
158. The dative is used in an ablative sense in such expressions as end urstêlen him sînes gôdes, and his property be stolen from him.

159. The dative may denote that with which something is compared : e.g., thi kining is him rîke and weldech, the king, in comparison with him, is mighty and great.

160. Nouns expressing the material or quantity of a substance, age, \&c., are put in the genitive: as, merk seloueris, a mark of silver; ên skilling goldes, a shilling of gold.

161. Partitives govern the genitive: e.g., alsâ stôr hêvena, so much of possessions; aller monna êk, every man; thera wedda awet, one of the pledges; thera ôthera ênich, any of the others.

162. Instead of the construction found in the Anglo-Saxon of two datives-(somewhat like the Latin double dative), the latter governed by $t \hat{o}$-in Friesic there is a genitive, and then a dative governed by that preposition: as, tô lioda londriuchte, as a statute for (of) the people.

\section{OF ADJECTIVES.}

163. Adjectives signifying worthiness, responsibility, plenty, want, guilt, ignorance, \&c., govern the noun in the genitive: e.g., thera êrana wel werth, truly worthy of honour; êniges jeldes schieldich, liable to a penalty; thes êthes $l d s$, free of the oath; lives and lethana unweldich, powerless over life and limb; sînes londes and sînes êthes weldech, master of his land and oath; thes wîges plichtich wesa, to have charge of the way.

164. Some adjectives require the dative, as, êna monna schieldich, liable to a man; him framd, foreign to him; jef hit him selua lief is, if it be agreeable to himself; hit sê ênre penningskelde lîc, let it be like a debt; Godi harsum, obedient unto God; dat zie da personna kund, let that be (made) known to the parson. 
165. Such adjectives as govern a dative of indirect object in other languages do so in Friesic.

166. Tha (than in West Lawers laws) and $s \hat{d}$ are used after comparatives : e.g., firor tha to tha Fli, farther than to the Fly ; mêr than the thrê dêlan, more than the three parts; hâgra sâ tuelf jerdfôta, higher than twelve feet.

167. Superlatives employed as partitives govern the genitive; as, alra beste, the best of all.

\section{OF PRONOUNS.}

168. An inclination of pronouns to contract with other words in the sentence has been explained in Sections 96 and 97.

169. Partitives govern the genitive: as, hwet werka, what of works.

170. The pronoun of the second person is very frequently omitted with the imperative : as, sei mi, tell me.

171. The dative of the pronoun exlibits a manifest tendency to supplant the accusative-a result which has been fully attained in English, in him and them. Thus in Friesic him is the direct objective of a transitive verb in many cases ; e.g., jef hi him urbaernt, if he burn him (i.e., prove him guilty by the fire ordeal); end ma him da schelta brinckt, and one take him to the magistrate; als $d$ se him siath, when they see him.

172. Reflexives are supplied by the personal pronouns with self (which, as in Anglo-Saxon, is inflected both after the weak and strong declension); sometimes without it: as, ik bem self, I am myself; sa sikure hine, so let him make himself safe. There is a later reflexive, sick, which is an intruder from the Dutch zich. 


\section{OF NUMERALS.}

173. The higher tens and hundreds of the cardinals sometimes govern the genitive: e.g., thrîtich merka, thirty (of) merks; then, again, they are found agreeing as adjectives with the substantives following.

174. (I.) The halves are expressed as in German and the Scandinavian languages, by the use of the ordinal of the number next higher than that wished to be expressed, with the word half following: e.g., thredda half pund, two and a half pounds; achtunda half skilling, seven and a half shillings. The whole numbers have been dropped out. The original construction is more easily understood from the following Anglo-Saxon example:- -hé waes pá twa gear and pridde healf, he was there two years and the third (year) half, i.e., two and a half years.

(2.) A similar idiom may be found in Greek (see Section 93). Thus,

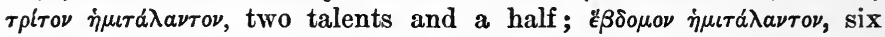
talents and a half : so in Sansk. ardha, half, with the ordinal, as in ardha tritîya, two and a half; ardha caturtha, three and a half. There is a word in Old-Friesic for two-thirds (twêde), used in precisely the same way.

175. Monig, an adjective, may be considered an indefinite numeral, and be used in the singular without the indefinite article, as in AngloSaxon and German. A.-S. rinc manig, many (a) man; Germ. mancher mann; Fries. hoe manich riucht ister, how many (a law is) laws are there?

176. The cardinal $\hat{e} n$ is employed as the indefinite article: e.g., ên gôd jeftha ên lond, property or a piece of land; ên ôtheres monnes wîf, another man's wife; et êna rümfâra, of a pilgrim.

\section{OF VERBS.}

177. Verbs govern the accusative when a direct object is expressed.

178. There is a cognate accusative, and also an accusative of specifi- 
cation, in Friesic, both of which will be found embodied in the follow ing sentence :-tha monne sîn gôd twijelde to jeldande, to make (pay) a double payment to the man (for) his property.

179. Verbs of influence, principally those of bidding, answering, controlling, withstanding, judging, repaying, imitating or being like to, pleasing, following, serving, coming upon, hearkening to, helping, speaking against, giving, forgiving, \&c., govern the dative. Examples :-

Sô bieda wy weduwen, so we bid widows.

Thet hi-t him ondwarde thes selua dis, that he answer to him for it the same day.

Til thiu thet ma tha ergon stiore, that men may control the evil-disposed.

Strîde withstonda, to withstand an attack.

Hi scel dêma tha fîunde alsâ friunde, he shall mete out justice to enemy as to friend.

Sâ skil hi jelda ... alle liodon, so shall he reward all people.

Hy lyketh een stum minscha, he is like unto a foolish man.

Thet bihagada tha biskope, that pleased the bishop.

Ther tha riuchte folgiat, who follow the right.

Tham skaltu thianja, him shalt thou serve.

Thet him bikume hunger, that hunger come upon him.

Leyntuler . . . herckia (Jur. Fris. ii. 226), to hearken to a liar.

Helpa tha erma, to help the poor.

And hir with sêke ma, and if one do speak against her.

Sîne kindem jewa, to give to his children.

Thet retse-ma tha nêste bi there fethersîda, that shall be delivered to his nearest relation on his father's side.

Tha tian bodo ther God urjef Moysese, the ten commandments which God gave to Moses.

Hi scanctum (for scancte him) bêthe mede and wîn, he offered him both mead and wine.

Sâ werth him edêmad and edèled thiu hille, then shall hell be allotted and appointed unto him.

$S \hat{a}$ betere hire mith fullere bôte, so pay her the full penalty.

180. Walda, to govern, wield; wachtja, to take care for, provide against; plegja, to take care of ; bidda, to request; missa, to miss, want; baga, to boast of; bitila, to obtain; brûka, to use (this verb also governs the accusative); varja, to 
keep, observe; undgunga, and other verbs signifying to free one from anything, govern the genitive : e.g.-

Thâ thi kining Kerl and thi pâus Leo thes rûmeska rîkes wîldon, when

King Charles and Pope Leo ruled the Roman world.

Sâ skel hi thes wachtja, he shall take care as to this.

Riuchtes plegja, to practise right.

$\hat{E}$ nes onderdes bidd-ic, I request an answer.

Mangra duget missa, to want many virtues.

Dis bagaden, of it they boasted.

Alsô brûc thu thînes lîwis, so employ thy life.

Thes fretha to warande, to keep the peace.

Thes mith niugun skeron untgunga, to free one's self from it with nine irons (the ordeal of the red-hot irons).

Sô aegh hy dis sexasum on $(t)$ swera, he must with five others swear himself free from it.

181. $J a$, to admit, governs both the accusative and genitive: e.g., jeth hi then' $c \hat{a} p$, if he admit the purchase; jef hi thes jech, if he admit it.

182. Undriuchta, legally to purge; helpa, to help; birâvja, to rob, bereave; and bitigja, to complain of, accuse, have an accusative or dative of the more direct, and a genitive of the remote, object, as :-

$Y$ habbet mi birâwed mines riuchtes, you have robbed me of my right. Sâ môt thiu môder hire kind thes lives helpa, so may the mother save her child's life.

Hwasû ôtherem thes betigath, whoever accuses another of it.

Sâ undriuchte hiu him thes tichta, so shall she free him from the charge.

183. Binima, to take from, takes an accusative of the thing and a dative of the person : e.g., hwa-sâ ôthere monne sin quic binimath, when one takes another's cattle.

184. The following verbs, impersonals, \&c., likja, to please; thinka (thinsja, tinsa), to seem to; bersta, deficere, to fail, be wanting (though this has also the primary signification of "to burst"); and bera, decere, govern their logical subject in the dative, as :-

Him thinsje, it may seem to him.

Lîkath hit him sa, if he like it.

Jef him sinra friunda enich bersta, if any of his friends fail him.

Alsâ stôr sâ him bereth, so great as becometh him. 
185. Breka, deficere, has a dative of the logical subject and a genitive of the remote object: brecht him thes riuchtes, if he have not justice (lit. if there be a failure to him of justice).

186. Instead of the two accusatives, one of the person and the other of the thing, found in Anglo-Saxon after the verb ácsian, to ask, in Friesic there is a dative of the person preceded by $t \hat{o}$, and an accusative of the thing: e.g., tô hwam-sât ma ên lond âskje, from (to) whomsoever one shall demand land.

187. With makja, to make, in addition to the double accusative of the person or thing, and of the predicate, there occurs the same construction as in Anglo-Saxon, viz., of the predicate in the dative preceded by tô : tô bona makja, to make one out (for) a murderer.

188. The present is, as in Anglo-Saxon, and sometimes in Sanskrit and many other languages, continually used for the expression of future time: as in sâther sâ ên dêd edên werth, when a deed shall be done; sa gunch hit ova sîn ein erva, so shall it enter upon its own inheritance: cf. Sansk. praveśayami; I introduce (them), for "I shall introduce them."

\section{THE SUBJUNCTIVE.}

I. (r.) The subjunctive is used to express what is indefinite, a wish, a doubt or possibility : as, sey mi haet Godes riucht sê, tell me what is God's law; hwersô een riuchter onriuchte riucht finde, whenever a judge shall find an unjust law.

(2.) It is used for all the persons of the imperative except the second: e.g., sâ geie hi mith fiuwer hageste mercum, then let him pay five "best" marks.

The subjunctive employed in this way will be found all through the laws, the formula being, "if one do such-andsuch a wrong, then let (subjunctive) him pay so much," or, "be punished thus and so."

\section{In dependent sentences :-}

Deer ma ... ur seyde and ênich man ... dat hi sines haudis schieldich wêre, where one said to any man that he had forfeited his life.

Istet ac thet ma tha rêdane with sedze, but if it be so that one oppose the testamentary disposition. 
After verbs :-

(I.) Of bidding, commanding :-

God ebâd thet wi hîlde, God commanded that we should keep.

(2.) To express purpose :-

Thit is . . Kynig Kerles jeft, theter allera monna êk ana sîna eyna gôde bisitte vmberâvad, this is King Charles's gift (or will) that every man shall possess his own property unmolested.

(3.) To express what is fitting:-

And quethen dat hit bettera wyr dat hy allîna driuckte, and said it were better that he alone should drown.

Thit is riucht thet him sina friond helpe, it is right that his friends should help him.

(4.) In conditional clauses, usually with jef:-

Sâ-hwer-sá ma thêr fon thes kininges haluon sôchte tô êna monne, jef hit him ur kôme, when one would inquire on behalf of the king if he were convicted (lit., if it were proved on him).

(5.) So in concessive clauses with thach.

Sâ nimath hia tha lawa, anda thiu suster nawt, thâch hiu libbende $s \hat{e}$, so shall they have the inheritance and the sister not, though she be living.

(6.) So, generally, the subjunctive is employed very freely in Old Friesic to express a variety of hypothetical, indefinite, and uncertain notions. The Laws being the only documents that have survived, they very naturally, and continually, put a hypothetical case of an infraction thereof, and then indicate the penalty.

\section{PARTICIPLES AND GERUND.}

190. The active participle in -and has sometimes a passive sense when used as a noun, as tha drivanda and tha dreganda, cattle and movables (literally things driven and drawn). So also has the gerund, as, te wetande mith twäm dêdêthon, to be proved by two solemn oaths (juramentis probationis).

191. (I.) The gerund is the dative of the infinitive, which latter is a verbal noun. There is a genitive of the gerund, nemennes. It remains to be explained why the dental $d$ has 
crept into the gerund in so many instances. The infinitive in Friesic has lost the final $n$ which characterises it in Anglo-Saxon, \&c. In the formation of the gerund, however, the liquid reasserted itself (sometimes in a geminated form) before the termination of the dative, as in tô farane, to journey; tô sêkane, to seek; tô stiftane, adificare, \&c.; but on account of the similarity of the form to that of the present participle, and because of the gerund's origin having been forgotten, the form of the participle with the proper case-ending was adopted. To this may also be undoubtedly added some notion of euphony involved in the selection of the participial form.

(2.) The case-ending is frequently omitted, as in tô gongen, to go ; tô halden, to hold ; tô wesan, tô wessen, to be, \&c.

(3.) Interesting in this connection is a peculiarity of the Modern Friesic, in adding $d$ to the pret. part., as in deend, done ; siend, seen; Hindelopian, drînd, portatus, latus, from draga.

192. The intensive prefix ge-, so freely used in AngloSaxon with the preterit and the past participle, occurs in Friesic principally in the forms $e, i$, or $i e$, and then almost exclusively with the participle, as e-fullad, from fullja, confirmare; e-felled, solutus; e-fêrin, peregrinatus; i-dên, done; ie-bunden, bound. Observe, however, e-bâd, pret. of biada, to bid. $e$ is also a privative particle equal to A.-S. $a$ - and Dutch ont-; as e-breka, deficere, deesse; A.-S. a-brecan, Dutch ontbreken; e-fella, e-felle, decoriatus, Dutch ontveld; e-frethe, sine pace; e-lende, exile; e-lîve, dead, (without life.)

\section{PREPOSITIONS.}

193. The following govern the accusative alone:-

$a$, from

afara, before

afori, for

alinga, * allenga, along

fori, for, instead of ont, until, up to

ovir, ur, for, against, at

thruch, through, by means of umbe, around, about, concerning with, withir, against

* Governs the genitive once. See section 196.

+ Governs the instrumental once. See section 197. 


\section{Examples of THeir Use.}

And hit A colc egendzin is, and it (the eye) is gone from its socket. AFARA thene warfa gunga, to go before the assembly.

AFORI thera dêda allerêk ên skilling, for every act a shilling.

Allenga thrê wirsna, along three wrinkles.

ForI hini ênne êth tô swerande, to swear for him.

ONT middey, until midday.

Oven thet hef, over the sea.

UR hine, over him.

Hwasâ wîf UR wald and UR willa nome, whoever shall take a woman by force and against her will.

Thruch thet lîf, through life.

UMBE thet morth, about the murder.

Thet nên hûsmon wiTH sînne hêra ne strîde, that no tenant fight with (against) his lord.

Tha Frisa thingadon wITHIR thene Kining Kerl, the Friesians contended against Charlemagne.

194. The following govern the dative only:-

befta, behind

bifara, before

bihalva, except

binêtha, beneath

binna, ${ }^{*}$ within

bova, above, over

$e$, out of, by, on

efta, behind

$\hat{e} r$, before

$e t$, at, of, to, \&c.

fara, before

fon, of, from
midda, among
mith, mey, with.
mong, among
nei, nâ, after, according to
$o f$, of, from, in
$t \hat{o}, t e$, to, in, at
$u p, u p p e r$, over, before
$\hat{u} t$, out of
$\hat{u} t a, \hat{u} t e$, out of
midda, among mith, mey, with. mong, among $n e i, n \hat{a}$, after, according to of, of, from, in tô, te, to, in, at up, upper, over, before $\hat{u t}$, out of ûta, ûte, out of

\section{EXAMPLES OF THEIR USE.}

And hia BEFTA hiam ne lêrath feder ne môder, and they leave not after them father or mother.

Bifara Walburge dey, before Walpurgis day.

Bihalva twam skillingon, except two shillings.

BINÊTHA + gerdle, beneath the girdle.

Binna jêra and Binna dey, within a year and a day.

Bova alle bergon, above all the mountains.

E ta sogen holem, out of the seven cavities.

EFTA tha durun stonda, to stand behind the doors.

* Governs the genitive once. See section 196.

+ Binêtha was anciently used only in the cities, or in the speech of the more refined. The country Frisians employed under. 
ÊR tha Sunnandei, before Sunday.

Thet kâpade ik ET êna rûmfara, that I bought of a pilgrim.

ET holi and ET herna, at a hole and in a corner.

FARA alle Godis hêligon, before all God's holy relics.

Fon êne undôme ur wnnen, convicted of unjust judgment.

Thi Keysere Fon Rume, the Emperor of Rome.

MIDDA alle Riostringon, among all the Rüstringer.

MrTH fiuwer monnon, with four men.

MoNG tha hêre, among the hair.

$\mathrm{N} \hat{\mathrm{A}}$ sine aynes riuchteres wordem, according to his own judge's words (decree).

NeI gâstlikka riuchte, according to ecclesiastical law.

Werth ên kind ht of londe lat, if a child be led captive out of the land. To londe and To liodon sinon, to its (the child's) fatherland and people. TE londriuchte, for a statute.

UPPER bêre and upper benke and upper grêwe, over bier, bench, and grave.

UPPER sîne rêdjevem, before his judges.

Ût sine hûse, out of his house.

Hwersâ mar ênne mon ÚTA (ût-tha) hûse bernt, whoever shall burn a man out of his house.

Thet him thet blôd UTA tha snabbe rent, that the blood run out of his mouth.

195. Prepositions governing the dative and accusative :-

$A$, on, in, to, by ; (also governs genitive once)

Ajen, against

$A n$, on, in, to, by

Ana, anna, in, to, on, into, by

And, anda, ande, in, on, to, over

Buppa, over, above, against

Bûta, outside, without, except

Efter, ${ }^{*}$ after

$E n$, in

$I n$, in, to, into

Inna, in, within, into

Inur (inor, inover), over, in, beyond
Jens, jons, jenst, jen, against (also Tô-jonis).

On, on, in, against

Oni (one, on, ane, an), without, less

op, oppa, opa, uppa, on, upon, against

Ova, upon, over

Sunder, sonder, without

Tô-fara, before

Twisk $a$, twischa, between, within

Under, under

$\hat{U} t e r$, utir, $\hat{u} t u r$, without, out of

EXAMPLES OF THEIR USE.

A himele and $\mathbf{A}$ erthe, in heaven and on earth.

Sâ hwer sâ ma ênne mon A morth sleith, whosoever shall put a man to death.

* Governs the genitive once; vide section 196. Also the instrumental, section 197. 
AJEN lîke dêthum, against like deeds. AJEN thene otheren, against the other.

Lesoka AN tha forhafde, wrinkles on the forehead.

AN wetir and AN wasa, on water and on turf.

ANA Saxsona merkon, by Saxon marks.

$\hat{E} n n e$ mon werpa ANA ên unlende weter, to cast a man into deep water.

ANDE sine rîke, in his kingdom.

AND thet lond, to that land.

Jef hit is BUPPA twâm pondem, if it be over two pounds.

BUPPA vyf merk, over five merks.

Blôdrisne . . B BÔTA clâthon, a bloody wound outside the clothing.

Nên manniska BÛTA God al êna, no man, but God alone.

EFTER thes monnes dathe, after the man's death.

EFTER sonne sêdel, after sunset.

S'â skelen tha dêda EN riuchta serifta stonda, so shall the deeds stand recorded in proper writing.

EN plê and EN plicht, in danger and solicitude.

IN ên strîde tô dâde slayn, to kill in strife.

Is den field fara, to go into the field.

Sâ hwo sâ ênne mon bernt. INNA êna hûse, whoever shall burn a man in a house.

Fliucht hi INNA hof and INNA hus, if he fly into a court and into a house.

INoR $\hat{u} s$ Fresche riuchte, beyond our Friesic law.

North ur hef jeftha suither INUR berch, northward over the sea, or southward over the mountain.

JENs-ter wirde, against the truth.

JENS dîne biscop, against thy bishop.

ON tha sôgenda mônathe, on the seventh month.

ON tha hêran fiugta bigunde, began to contend against the lords.

Fiuwer skillinga oNI thrium panning, four shillings less threepence.

AN sŷne willa, without his permission.

Di prêster schil oP da hofwal stcen, the priest shall stand on the churchyard wall

Jef een huisman oP êne ôdera claget, if a citizen complain of another. OPA tha hêligon tô swerande, to swear upon the holy relics.

UPPA thet hlênbed, upon a sick-bed.

Ova tha hêligon, upon the relics.

OUA sin ein erue, upon his own inheritance.

SUNDER hûsbrêke... jeftha sUNDER bronde, without burglary or arson.

SONDER wandel, without change.

Tô FARA tha keysere, before the emperor.

Tô FARA dat ansicht, before the face.

'Tuischa da Eemse ende Westfalen, between the Ems and Westphalia. 
Twisk thene feder and TwISk thene sunu, between father and son.

UNDER tha neyle, under the nail.

UNDER riucht, under law.

ÛTER strîde, without contest.

UTTER stef and UTER strîd, without oath or contest.

196. Of the use of prepositions with the genitive there is little trace; the examples are confined to the following:BINNA thes hases, within the house; BINNAS gaes, within the district; BIHALVA thes, except this; EFTER thes, an adverbial phrase signifying thereafter; ALONT des Saterdeis, up to Saturday; A tuîra wegena, twofold ; ONDLENG-es wîes, along the way.

197. Prepositions governing the instrumental and other cases :-

$B i$, by (dative and instrumental).

Efter, after, according to (genitive, dative, accusative, and instrumental).

Til, to (dative and instrumental).

With, with, against (accusative and instrumental).

EXAMPLES.

Bi âsiga dôme, by command of the judge.

Bi thio, adv. phrase, therefore.

Efter dis, thereafter.

Efter dathe, after death.

Efter thes Kinig Kerles jeft, according to King Charles's Statute. Efter thiu, thereafter.

Til there Wisere, to the Weser.

Til thiu, adv. phrase, in order that.

WrTH thene Kining, against the King.

WITH thiu, adv. phrase, according as.

198. The Frisians, Saxons, and English are all fond of double prepositions ; for example, A.-S. on-gean, Eng. against; A.-S. upp-on, Eng. upon; Fries. tô-jenst, in-over, tô-fara, up-ur, \&c. A.-S. with-útan, Eng. without.

\section{CONJUNCTIONS.}

$\hat{a} c$, also, and

alsâ, so, also, as

and, and

buta, unless hweder, whether

jef, if

$\left.\begin{array}{l}\text { nâhweder } \\ \text { nauder }\end{array}\right\}$ neither ne, ni, not

$s \hat{a}$, so, as, or

thâ, either, or

thâch, yet, though

wara, wera, but 
200. The conjunction $s \hat{a}$, so, is a great favourite, especially in the introduction of the apodosis to conditional propositions. In this it materially differs from the English and Anglo-Saxon custom.

It is, however, very freely used, and not at all confined to that function, introducing many sentences somewhat as an expletive, where no conditional clause is previously expressed, as in sa hi alra beste muge, the best he can. This will at once attract the attention of the reader of the Old Friesic laws.

201. The following are the principal conjunctions which govern the subjunctive :-jef, if; thach, though ; thet, that.

\section{ADVERBS.}

202. The task of enumerating the adverbs must be left to the lexicon.

(I.) Naut, signifying nothing, is frequently employed as an adverb. Hond, hand, is also used in an adverbial sense in such expressions as, fon alra honda riuchte, of every kind of (Germ. allerhand, allerlei) law.

(2.) $H \hat{u}$ is a common interrogative-hî monich pund? how many pounds?

(3.) Two negatives do not neutralise each other, but even as many as three occur in one proposition, each one that follows strengthening the initial. The rule would seem to be to employ as many as possible; e.g., sâ ne mei-re helpa na nêne monne, so shall it be of use to no one.

(4.) $G \hat{e}$, as in so many other Germanic tongues, is the affirmative yea or yes.

(5.) $N a$ and ne are the negatives, the latter with the subjunctive.

(6.) The negative comes immediately before the verb, and this should be borne in mind in view of the frequent blending of the accusative of the personal pronoun and the demonstrative with a preceding word; for it cannot, as a rule, be the negative if it precede a noun or anything but a verb. 


\section{INTERJECTIONS.}

203. In view of the peculiar character of the literary remains of this language, one should naturally expect to find but few interjections preserved. The following occur:-gê, ha, wach, o, and êla. Gê God! Me Hercule! Mon Dieu! Da spreeck di Koningh Kaerl, "Ha! ha! dat land is myn," and hlachede-Then spoke King Charles, and said, "Ha! ha! the land is mine," and laughed. Dae spreek Radboed, "O! wach!" -Then said Radbod, "O! woe!"

Ela! frîa Fresena! Ho! free Frisians! Friesic of the Middle period presents the following:-Wi! awach! the leider! Oho! 


\section{$(90)$ \\ $P A R T I V$. \\ PROSODY.}

204. But a limited chapter can be devoted to prosody in an Old Friesic grammar, owing to the lack of poetry which we have from the time before the language's decay.

We possess a few brief fragments of songs, \&c., written in pure Friesic, such, for instance, as the following, exhibiting end-rhyme:-

" Hi was minnera

And hi was betera, Hi stifte and sterde

Trîwa and werde;

Ande hi setta thera kenega jeft

Ande allere liuda kest

And Londriucht,

And allera londa eccum sîn riucht." *

Another rhymed poem of evidently later date, which is a short account of an expedition of the Frisians against the Saxons, the taking of Rome by Charlemagne, and the Freiheidsbrief of the same to the Frisians, begins thus-

" Thit was tô there stunde,

Tha thi kening Kerl riuchta bigunde;

Tha was têr ande there Saxinna merik

Liudingerus, ên hêra fele steric ;

$H i$ welde him alsâ waldlîke

Tegathan, ther hi fon riuchta scolde bihalda

Tha kenig Kerlis kairsha rîke;

Âc welde hi ma duan,

Hi welde tha sterka Fresan vnder sinne tegetha tîan."

* Richthofen, Friesische Rechtsquellen, p. 343.

+ Thagethan.

¥Rechtsq., p. 351, reprinted in Hettema's Proeve van een Friesch en Nederl. Woordenboek, p. 100, and in Rieger's Lesebuch. 
205. Another reads thus-

"Forth scele wi se.halda

And God scel urse walda,

Thes reddera (teddera?) and thes stitha:

And alle unriuchte thing scele wi formitha."

"This thought let us henceforth retain, That God hath all beneath His reign;

He rules the weak, and eke the strong;

Oh! shun we then whate'er is wrong."

206. Of alliterative poems we quote from the laws (Rechtsq., p. 3).

Colnaburch hît bi Alda tîdon

Agrip Anda Alda noma;

Tha Firade $\hat{u}$ s Fison

Thiu Fire menote, And $\hat{u}$ s swerade

Tha thi swera panning

Setton tha selua

Sundroge menota, And warth ther with thet

Twa and sjuguntich punda

Leyd and eLagad,

Twâ and siuguntich skillinga

Rednathes slekes,

Jeftha Kawinges slekes.

Rednath and Kawing

Alsâ hîton tha Forma

Twêne ther to Frislonde

Then Pannig slôgon;

Thriu Pund tha frana;

Thet is ên and twintich

Skillingathruch thes kyningesbon.
Cologne was called in olden times Agrip by ancient name;

Then was strange to us Frisians

The foreign money,

And us burdened

Then the heavy coin.

Set we ourselves

A special money,

And therewith there were

Two and seventy pounds

Laid and valued,

Two and seventy shillings

Of Rednath's minting

Or of Kawing's stamp.

Rednath and Kawing

So were called the first

Two who in Friesland

The penny minted;

Three pounds to the magistrate;

That is one and twenty

Shillings by the king's decree.

207. In the laws of the Rüstringer (Friesische Rechtsq., p. $133,1.17 \mathrm{ff}$.) are to be found these alliterative lines, from a register of the kings who established good laws :-

Thesse fiuwer Hêra

BiHulpon is

Frison Frîhalses

And Frîdômes

With thene Kinig

$\mathrm{Kerl}$, hwande alle

Frisa er north Hêrdon

Anda grimma Herna
These four lords

Helped us

Frisians to liberty

And freedom

Against King Charles

Because all

Frisians to the north were subject

To fierce nations. 
208. There is a general fondness evinced in various parts of the laws for the grace of alliteration; and it is not a fancied grace ; it appears, unconsciously perhaps, to pervade nearly all poetical literature, especially English. There is no one who employs it, or who perhaps has employed it, with more elegance and dexterity than the poet Thomson.

The following is a remarkable example of it in Friesic prose, to which attention is called in the preface (p. vi.) of Leo's Angelsächsisches Glossar: *

"Dio forme nêd is, hwerso ên kind jong is Finsen ende Fitered north ur hef, jeftha 'sûther ur birg, so Môt dio Môder her kindes erve setta ende sella, ende her kind Lêsa end des Lîfes bihelpa; dio ôther nêd is, Jeftha Jêre diore werdat, end di Hêta Honger ur dat land fârt, ende dat kind Honger sterva wil,'so Mốt dio Mốder her kindes erve setta ende

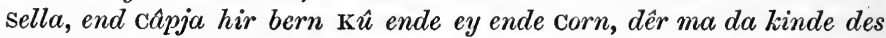
lîves mede helpe.

"Dio tredde nêd is, als dat kind is al stocknaken jeftha hûslâs, ende dan die tiuestra nevil ende calda winter onkomt, so fart aller monnîk on $\mathrm{H}$ of ende on $\mathrm{H}$ ùs ende on warane gaten ende dat wilda dier sêket din holla Bâm ende der Birga hly, aldêr hit sîn lîf on bihalda mei, so weinet ende schrît dat onjërige kind ende wîst dan sîn nakena lîa, ende sîn hûslâse, ende sîn fader der him reda schulde tojenst din honger, ende winter nevilkald, dat hi so Diepe ende Dimme mitta fiower neilen is onder êke Ende onder da Erda Bisloten ende Bitacht, so môt dio môder hir kindes erve setta ende sella."

209. It appears, from such few fragments as have reached us, as above indicated, that the Old-Friesic poetical characteristics are identical with those of the other ancient Teutons.

They principally consist in :-

(I.) Alliteration, viz., the beginning of several syllables in the same or corresponding verse with the same letter.

(2.) In rhythm or cadence, which is emphasis and remission.

(3.) The Friesic, like the Anglo-Saxon, is partial to the recurrence of consonants, and is inclined to thow the alliteration on the emphatic word or syllable.

210. Parallelism is very common in this verse ; in AngloSaxon, for example, a great number of expressions and metaphors, occupying many lines, will be employed in the

* Although this is the West Lanwers version, it is not its orthography. 
expression of a very simple idea: e.g., Cädmon occupies eighteen lines in a poetic paraphrase of the first verse of Genesis; so in the Friesic fragments given in this part traces of the same peculiarity are to be observed.

Thus:-

Thesse fiuwer hêra

Bihulpon tis

Frison frihalses

And frîdômes.

So also :-

Colnaburch hît by alda tîdon Agrip anda alda noma, \&c.

Cologne was called in olden times Agrip by ancient name.

211. The ancient Germanic bards sometimes added the grace of final rhyme to their verse. That Friesic did not deviate from the other dialects in this regard will be evident from the verse given at Sections 204 and 205.

212. "Of national popular songs in Frisian there are no traces, and yet..... the scene of Beowulf is partly on Frisian soil, and ..... Gudrun includes, mixed with its northern elements, many legendary events of Frisian history. There were Frisian bards, but their songs were never written, and consequently have perished. In the life of St. Liudger we find that he met at Hellewird a blind singer, Bernulf, who sang of the deeds and conflicts of the ancient Frisian kings, and who was greatly beloved by the people. These songs could only exist when the country was free from foreign influence, and where there was the bond of a national spirit and common history."*

213. Of Middle-Friesic poetry there is a work entitled Thet Freske Riim, a rambling and weak production in rhyme, written somewhere about A.D. I 400, and embracing sacred and fanciful secular history. There are two other rhymed works of this period, though of a little later date, and not in as good Friesic as the Riim. They are termed respectively Gesta Fresonum and Olde Freesche Chronike, and are of a character similar to the Freske Riim.

* Hewett, The Frisian Language, \&c., p. 20. 


\section{READING LESSONS.}

\section{THE TEN COMMANDMENTS.}

Thit riuht skrêf God selua, ûse hêra, thâ thet was thet Moyses lâtte thet Israhêliske folk thruch thene râda sê, and of there wilda wôstene, andse kômon tô tha berge, ther is ehêten Synay. Thâ festade Moyses twîa fiuwertich dega and nachta; thêr efter jef God him twâ stênena tefla, thêr hi on eskrîuin hede tha tian bodo, tha skolde hi lêra tha Israhêliska folke.

Thet was thet êrost bod:

Thin God thet is thi êna, ther skippere is himulrikes and irthrîkes, tham skaltu thianja.

Thet was thet ôther bod:

Thu ne skalt thînes Godes noma nâwet îdle untfâ; thêr mithi send ti urbêden alle mênêtha.

Thet was thet thredde bod:

Thu skalt fîrja thene hêlega Sunnandî. . . . .

Thet was thet fiarde bod:

Thu skalt êrja thînne feder and thîne môder, thet tv theste langor libbe.

Thet was thet fiffe bod:

Thu ne skalt nênne monslaga dva. 
Thet was thet sexte bod:

Thu ne skalt nên hôr thâ nên overhôr dûa, bûta mith thînere âfta wîue skaltu gôdilîke libba.

\section{Thet was thet sivgunde bod:}

Thu ne skalt nêne thiuvethe dûa, and ne skalt nâwet jerja ova thînes ivinkerstena haua, ther thi fon rivchta nâwet wertha ne mugun.

\section{Thet was thet achtunde bod:}

Thu ne skalt nên onriucht tiuch dûa.

\section{Thet was thet niugunde and thet tiande bod:}

Thu skalt minnja God thînne skippere mith rênere hirta and thînne ivinkerstena lîke thi selva. Thesse tuâ bodo beslûtath alle tha othera bodo.

Thet send tha tian bodo ther God urjef Moysese, and hi forth lêrde tha Israhêliska folk (thesse bodo hîldon hia tha fiuwertich jêra thase andere wôstene wêron) and lethogade hia fon monigere nêde and lâttese an thet lond thet flât fon melokon and fon hunige-thet was thet hêlege lond tô Jhêrusalem. Alsâ lât ûse hêra God alle tha tô tha himulrîke, ther tha riuchte folgjath, and alle tha ther thet riucht jeftha ênich riucht brekth (hit ne sê thet ma hit thruch nâtha dûe, thruch thet tha nâtha send mârra thâ thet riucht), sâ bislût hia God andere hille, alsâ hi bislât tha Egypta liode anda râda sê, thâse sîne liodon skathja weldon, tha Israhêliska folke.

\section{THE SIGNS AND WONDERS BEFORE THE DAY OF JUDGMENT.}

Thit send tha fîftine têkna ther êr Dômes dî koma skilun, ther Sancte Jêronimus fand eskrivin an thera Jôthana bôkon: Thes êrosta dîs sâ stîgath alle wetir fiuwertich fethma bova alle bergon, and stondath to lîkere wîs and thiu mûre ther fon stêne ewrocht is. Thes ôtheres dîs sâ werthathse lîk thera 
selva skipnese therse bifara wêron. Thes threddes dîs fallathse alsâ sîde, thetse nên âge bisîa ne mî. Thes fiarda dîs sâ somniatse alle fiskar ther send an tha wetiron to semine and hrôpath al tô Godi, and tha stifne nêt nên manniska bûta God al êna. Thes fifta dîs burnath alle wetir fon âsta there wralde to westa there wralde. Thes sexta dîs sâ send alle bâmar and alle gerso mith êna blôdiga dâwe bifangen. Thes siugunda dîs sâ fallath alle tha timber fon âsta there wralde to westa there wralde, and werthat al gâdur tôbreken. Thes achtunda dîs sâ falt thi stên withir thene stên, and tôbrekth al semin, and tha berga werthath eifnad. Thes niugunda dîs sâ werth alsâ grât irthbivinge sâ ther fon onbijenne there wralde êr nên sâ dên nâs. Thes tianda dîs werth thiu wrald emênad an thera selva skipnese therse was êrse ûse Drochten eskêpen hede. Thes andlofta dîs sâ gunth thi manniska with thene ôtherne, and ne mî nên mon ôtheron ondwardja fon there nêde and fon tha ongosta, hwande thenne is jahwelîk mon thes sinnes birâvad. Thes twilifta dîs sâ werth egâdurad alle thet bênete efter there wralde anna êne stidi. Thes threddinda dîs sâ fallath alle tha stera fon tha himule. Thes fiuwertînda dîs sâ stervath alle tha liode and skilun thêr efter up stonda mith ôthera clâthon. Thes fiftînda dîs sâ burnt alle thiu wrald, fon âsta there wralde tô westa there wralde al tô there hille porta. Thêr efter werth dômes dî; sâ cumth ûse hêra mith alle sîne anglon, and mith alle sîne hêligon; sâ bevath alle thiu wrald alsâ thet espene lâf, alsâse hini sîath mith tha criose and mith tha spiri and mith tha neylon and mith there thornena crôna, and mith tha fîf wndon, ther hi an tha criose tholade furi ûs and fori al mannesklîk slachte.

\section{CREATION OF MAN.}

God scôp thene êresta meneska, thet was Adam, fon achta wendem : thet bênete fon tha stêne, thet flâsk fon there erthe, thet blôd fon tha wetere, tha herta fon tha winde, thene tôgta fon ta wolken, the suêt fon tha dâwe, tha lokkar fon tha gerse, tha âgrene fon there sunna; and thâ blêrem on thene hêlga ôm; and thâ scôpe Eva fon sîne ribbe, Adamesliana. 


\section{LAWS.}

From the Seventeen Privileges of the Frisian

People. Ca. I 200.

\section{Rüstringer T'ext.}

Septima petitio: Thit is thiu siugunde liodkest, thet alle Frisa an frîa stôle bisitte, and hebbe frîa sprêka and frî ondwarde; thet ur jef us thi kinig Kerl, til thiu thet wi Frisa sûther nîgi, and clipskelde urtêge, and wrthe tha suthera kininge hanzoch and hêroch alles riuchtes tinzes, and tegôtha and hûslotha ur gulde bi âsiga dôme and bi lioda londriuchte, al with thet wi êr north hêrdon Rêdbate tha unfrethmonne, al thet Frisona was.

\section{Undecima Petitio.-Hunsingoer.}

Thet is thiu ellefte kest; frethe alle widem and wêsum, and alle unjêrige bernum, and alle warlâsa liudem, palmerum and rûmfârum, and alle riuchte pilegrimum, and alle karefestrum, hêlgena sende-bodum, bi tian liudmerkum; and tham tuîwalte bôte, ther wi and wêpen ur esueren hebbe, thruch frethe and nêthe; end ên antuintech scillenga tha frana.

\section{Decima Petitio.-Emsiger.}

(Not before the beginning of the fifteenth century.)

Thet istiu tiande kest, thet Fresa ne thurven nêne herefert firer fâra thâ âster tô there Wisere and wester thô Flí, thruch thet hia hira lond behêlde witha wilda heve and withene hêthene here. Thâ bêd thi keneng Kerl thet hia firer tha hereferda fôre, âster to Hiddisheckere and wester tô Sincfalum. Thâ bihêlden hit tha liude withene keneng Kerl, thet hia firer tnêne herferd fâra ne thorste sâ âster thô there Wisere and wester tô tha Flî. Thruch thet scelen alle Fresa fon tha northliudem frî wesa. 


\section{From the Laws of Brokmer Land.}

\section{Fon tha Monne Ther Flivith Inna T'syurka.}

Jef hîr ên mon fliûth inna tsyureka, and tha fiund hine thêr on gêlath, al thet hi thenna bîre nêdwere dêth, thet lidse gresfelle. Wirgath ma hine thêr on, sâ geldema hine mith fîfta halwe jelde, and tha liudem hunder merca, and thet hûs thera liuda. Nêl hi thenna naut of unga, alsâ tha fiund fon ungath bi hêlgena monna, and bi rêdgewena worde, sâ rêsze hi alsâ stôr, alsâ thi ther tha tsyurka bifêth. And hwasâre ênne mon âsleyt innâre tsyurika, sâ rêsze hi hunder merca tha liudem and sexthech tha hêlegum; nêllath hia of there tsyurka nauvet unga, thêrre thenne on send, sâ unge thi rêdja, ther ur tha tsyurka sueren hêth, and kêthese of. Nêllet hia nâwet of unga, sâ berne hi thet forme bêken bi achta mercum thes selwa deis; and ne ungat hia thenna naut of, sâ berne alle sine sithar tha bêkene thes letera deis and sogenje tha liude, alrêc hira bi achta mercum ; and hôc hira sâ tha bêkene naut ne bernt and sîne liude naut ne brench, sâ lêdema oppa hine alra êrest, and fiuch hi with tha sîthar, sâ felle hît a tuîra wegena.

\section{The Twenty-fourth General Statute:}

\section{Rüstringer, Thirteenth Century.}

Thit is thit fiuwer and twintigoste londriucht: sâ-hwa-sâ tô ôtheron fâri nachtes to houi and tô hûse bi slêpandere thiade and bi unwisssa wâkandon, mith ênere glândere glêde, and al thet gôd barnt ther hi hêth an houi and an hûse, an weron and an waruon; jef hi ja wili, sâ skil hi kuma et thera fiuwer hernana hwelîk mith tian merkon, weddja skilre an dôm with tha liode, and et there hirthstidi mith sinere hauedlesne, and tha moune sîn gôd twijelde tô jeldande, alsâ hit sîna bûra jeftha sîna umbibûrar mith him swera willath. Jef hi bisêka wili, sâ skil hi et thera herna hwêk and strîde with stonda mith fiuwer berskinzia campon, and et there hirthstidi mith tha fifta campa, thruch thet thet ma morth skil mith morthe kêla. 


\section{The Fourteenth Statute.}

\section{West Lauwers.}

Dat fiaertienste landriucht is: Sô-hwa-sô anderem faert tô hou ende tô huis mit een op riuchta fana ane lioda werd, ende bûta frâna ban ênis dômliachtes deis, sô-haet-sô ma deer inoer hoff ende huis dêth, dat is tuybeet; ende alle dat ma deer wr dêth of deer needver, dat sel vessa al eenferd ende eenbeet. Des âgen him da lioed ende di frâna tô helpane, om dat him hi haudlase tô commen was.

\section{Fourteenth General Statute.}

\section{Emsiger.}

Thet istet fiuwertêndeste londriuchte : Sâ-hua-sâ ôthere dêth êne wapeldêp jeftha êne suertnesueng, jefta ên unsceldegne bint, jeftha a bonnane fretha unriucht râf dêth, jeftha sonnendeis blôdelsa; sâ istera jahuelîkes bôte fîftêna enza; hit ne sê thette bisêke, sâ âch hi te riuchtane mit fiuwer wîthêthum and mith êne fiaêthe, bi allera Fresana riuchte.

\section{From the Additional Rüstringer Statutes.}

Thet is âc londriucht, thet wi Frisa hâgon êne sêburch tô stiftande and tô stêrande, ênne geldene hôp, ther umbe al Frislond lîth; thêr skil on wesa allera jerdîk iuin hâr ôron. Thêr thi salta sê bêtha thes dîs antes nachtes tô swilith, thêr skil thi ûtrosta anti inrosta thes wîges plichtich wesa, tha strête thes wintres and thes sumures mith wegke, and mith weine tô fârande, thet thi wein tha ôron mêta mugi. Alsâ thi inrosta tô tha dîke cumth, sâ hâgere alsâ grâtene fretho opa tha dîke alsâre oua tha wîlâsa werpe, and alsâre oua tha weida stherekhoui; hêth thêre thenne bûta dîke alsâ felo hêles londes and grênes turues, thetterne dîkstathul mithi halda mugi *; âc nêchthêre nauwet sâ felo bûta dîke hêles londes and

* The conclusion is wanting. 
grênes turues, thettêrne dîk mithi halda mugi, sâ hâgere binna dîke thrîtich fôta turues and thrîtich fethma tô gerse; thet skil wesa alla fennon anda fili êr Sante Vîtes dî. Ûta skilu wi Frisa ûse lond halda mith thrium tauwon; mith tha spada and mith there bêra, and mith there forke: âc skilu wi ûse lond wera mith egge and mith orde, and mith tha brûna skelde with thene stâpa helm and with thene râda skeld and with thet unriuchte hêrskipi. Aldus skilu wi Frisa halda ûse lond fon oua tô ûta, jef ûs God helpa wili and Sante Pêderr.

\section{MIDDLE-FRIESIC PERIOD.}

From the Jus Municipale Frisonum, ii. 63.

(Latter half of fifteenth century.)

Dae di koning Kaerle ende di koning Rêdbad fan Danemerkum in dat land kômen, dae bisette eelk zyn burch in Fraenekraghae mey êne herescelde, end êlck seyd, dat land weer zyn. Dae wolden se wîse lioede jerne sêna, ende dae hêren wolden hit bistrîda; dôch wysda ma dir sône alsô langhe, dat ma hit op dae tweer koningen joed hoekra oerem oen stilla stalle wrstoed, dat hi dat land winnen hede. Dae brôchte ma dae hêran toe gaera, ende hia stoeden ên eetmel allomme. Dae leet him di koning Kaerle zyn handschoegh oenfalla; dae rechtan him di koningh Rêdbad. Dae spreeck de koning Kaerle, oho !-(O. text, Ha! ha! dat land is myn)ende hlackade. Deerom heet zyn burch Hochenzie. Dae spreec di koneng Kaerle; dit landt is myn. Hweerom? spreek di oera. I sint myn tianstmane werden. $\mathrm{O}$ ! wach! spreek Rêdbad. Aldeerom heet Rêdbadis burch Wachenzie.

From the Jurisprudentia Frisica, ii. 6 and 8.

(A manuscript of the fifteenth century, containing mostly Roman and Canonical law.)

Ws Freesck landriucht seyt, dyr ws byfellen is tô halden bij ws seel ende bij da hâge hymelryck ende bij ws Cristena 
nama; dat aller mannîck an syn ayna gued bysitte, ende oen syn heuen, ende oen syn weren, aldes hij bytilet habbe; hit ne sê dat mê-t hym oeffwynna mey tâle ende myt rêden ende mey riuchta tingade. Hyr op so concorderet aeck dyo ârste kest.

Item.-Hyr op sô seyt aeck dat scrioun riucht: dat me nimmen syn besit nyma schil, mer alle lyode ys ma schyldich in da besit tô beschirmen in syn besittinghe, ont ter tyd dat ma hym dyo besittinghe offwyn mit riucht.

Aldus spreckt dij Keyser in syn riucht: hwasô compt in alzô grâter dorsticheit ende dwalicheit, dat têr een mynscha een besittinghe ênis tingis fan ôra lyodem bynympt, wrwyeldelyck myt wyeld, sonder oerloff des riuchters, eer hit him dy riuchter tô der hand deeld haet, so schel dijjen, deer da besittinghe dis tinghes nymen haet, weer rêka da besittera; ende dij sitter, dyr da wyeld deen" haet, dy foerlyest dat heerscip desselue tinges; ende weer-t dat têr een onayna besittinghe naem, ende myt riucht naet oencomma mucht, sô schill er naet allyne da onryuchta besittinghe weer jaen, mer alzô folla, als dat gued wird is, aldeer tô : hwant neen minscha syn ayn riuchter ende macht wessa mey in neen tyngh.

\section{From the East Frisian Lantrecht of $1527 . *$}

Richth., p. 48, note.

Dat anderde lantrecht is: Dat de môder mach eres kyndes goet nicht verkôpen, eder des kindes erue nicht vorwesselen, oeck mit der kinder vronde willen; id sy dan, want de kynder tô eren yâren kômen, sô danen koep eder wesselinghe beleuen, dat is want de kinder xxv jâren olt sinnen. Des gelyken moegen de voermunders vnd testamentars, oeck nicht der kinderen goet vorwesselen eder verkôpen eder voranderen; is-t datse nicht dat willen beleuen (lâten) moegen de kynder eer arue antasten vnd besitten, waerse dat vinden.

* Grimm (Gesch. d. deutsche Spr., p. 47I) considers that the East Frisians are the direct descendants of the ancient Chauci, and are not Frisians at all, which the fact of their location, and the improbability of that tribe being utterly left without descendants, renders extremely plausible. 
22 d Statute, MS. Zyl. V. I 559.-Richth. p. 74, note.

Dat xxii lantrecht vormeldet dat de verbeteringe ênes êdelen mans vrouwen in oren gûderen, dârse van den heerde schedet, vnd dat guedt sick vormeret heft by oeren tyden, so schalmen oer geuen wan de man doet is roo pundt. Desgelycken want eyn êgen eruede vrouwe aff den heert schedet vnd de gûderen verbeteret synnen, sô schalmen oer geuen na ores mannes doet viii punt, viii schillinghe, viii ense vnd viii penninge, na vthwysinge des olden Ffreeschen lantrechtes.

\section{VERSE.}

Thet Freske Riim, A.D. 1400.

Ik sculde sega, of ic cûde, Ho di frîdôm aerst bigûde, Thâ thio werrild êrst dêde forgaen, And thio ôther dêde ingaen,

Aldus biscrîuet Alwyn,

Thi Mâster, in tha bôke syn ;

Thâ thi flôde dêde opgaen,

And dêdet alle forslaen.

Hir Noe sprack; nu skil icket thi cund dwan Hôt ic in tha wralda habbe dân, And thet scilt riocht forestân. Thi Inghel van himel tô mi com, And $\mathrm{mi}$ in sine raed nom, And seide mi openbaer, Thet thi Himelsche Koning forbolgen waer, And alle thio wralde scolde wrgaen,

Bêde wyf ende man, And al thattêr lyf had untfân ; Sonder mi ande thi end wse sonen cone And hârra frôwan scône ; And wi scillad in tha arck gân. 


\section{MODERN FRIESIC.}

From Gysbert Japickx, Friesche Rijmlerije.

(Middle of the seventeenth century.)

A rustic song supposed to be sung by a peasant on his return from a wedding feast. (See Halbertsma's Preface, p. lxxii., to Bosworth's Anglo-Saxon Dictionary.)

Swiet, ja swiet is't oer'e miete

'T boáskien fóar'e jonge lie; Kreftich swiet is't, sizz'ik jiette, As it giet mei âlders rie. Mar óars tiget 'et to'n pléach, As ik óan myn géafeint séach.

Goune Swobke, lit uws péarje, Béa hy her mii mylde stem, Ofke, sei se, ho scoe'k it kléarje?

Wist du rie to heite in mem?

Ljeaf, dat nym ik to myn lasst. Dear mei wier dy knôte frest.

Da dit pear to géar scoe ite,

In hjoe hiene nin gewin, Heite séach as woe hy bite

Mem wier stjoersch in leffen sin.

Ofke, sei se, elk jier ien bernWier ik fáem! ik woe't so jern.

Ork, myn sóan, wolt du bedye,

Rin náet óan allyk ien moll'! Jeld in rie lit mei dy frye,

Bern, so géan' dyn saken wol; Den scil de himel uwr dyn dwáen Lok in mylde seining jáen.
Sweet, yea sweet is it over measure,

The marrying for the young folk; Most sweet is it I say yet

When it goes with elders' advice. But otherwise it tends to a plague, As I saw by my village fellow.

Golden Swobke, let us wed (pair), $\mathrm{He}$ bade her with mild voice.

Ofke, said she, how should I clear it?

Canst thou right it with father and mother?

Beloved, I take this to my charge. Therewith the knot was fast.

When this pair would eat together,

And they had no earnings,

Father (husband) looked as if he'd bite,

Mother (wife) was stern and harsh of humour.

Ofke, said she, each year a childWere I a maid! I wish it so !

Ork, my son, would'st thou prosper,

Run not on all like a mole !

Let age and counsel woo with thee,

Child, then thy affairs go well ; Then shall Heaven o'er thy doings Give luck and mild blessings. 


\section{Proverbs, Seventeenth Century.}

Hoeuft, Oude Friesche Spreek-Woorden, passim.

Aade foxen binnen quae to fan-Old foxes are hard to take.

Better ien blyn hynst as ien leech helter-Better a blind horse than an empty halter.

Folle wirden follen nin seck-Many words fill no sack.

Hat d'aade sjonge, pypje de jonge-What the old ones sing the young ones pipe.

Krockjende weijen doerje allerlanghst_Creaking waggons last the longest.

Langh festjen is nin brce sperjen-Long fasting saves no bread.

Rop nin haring, crstese int net heste-Cry not "herring" till you have it in the net.

Wol beguwn is hast spuxn-Well begun is quickly spun.

\section{MODERN COUNTRY FRIESIC.}

Stanzas by the Countess of Blessington.

Bosw. Dic., Pref., p. Ixxi.

Hwat bist dou, libben?

Ien wirch stribjen

Fen pine, noed in soárch;

Lange oeren fen smerte,

In nochten-ho kourt!

Det fordwine de moárns.

Déad, hwat bist dou,

Ta hwaem allen buwgje,

Fen de scepterde kening ta de slawe?

De latste, baste fréon,

Om uws soargen to eingjen,

Dyn gebiet is yn't graf.

Wenneer se allen binne fled

Jouwst dou ien bad,

War wy kalm yn sliepe:

De wounen alle hele,

De digerige éagen segele,

Dy lang diene wekje in gepje.
What art thou, life?

A weary strife

Of pain, care, and sorrow ;

Long hours of grief,

And joys-how brief !

That vanish (on) the morrow.

Death, what art thou, To whom all bow,

From sceptered king to slave?

The last, best friend,

Our eares to end,

Thy empire's in the grave.

When all have fled

'Thou giv'st a bed,

Wherein we calmly sleep :

The wounds all healed, The dim eyes sealed, That long did wake and weep. 


\section{WEST-FRIESIC. \\ Colmjon, Beknopte Friesche Spraakkunst, p. гоз.}

LUKE XV.

I. End der kamen by him alderhânde soarte fen tolgarders end súnders, um him to heren.

2. En de farisiewen end de skriftlearden dy gnoärren end seiden : disse nimt de súnders oan, end dy it mei hiar.

3. End hy spriek tsjin hiar disse likenis, sidzende:

4. Hwet minske is der únder jimme, by húnderd skiep heth; end as er ien der fen forliest, dy net de niugen end niugentich ín'e wôestine lit, end der up út giët nei't forlerne, oant er dat finth?

\section{HINDELOPIAN.}

Bosworth, Preface, p. lxxiv., from a Calendar for Seamen.

Jannarius het xxxi deggen, Nyje deggen, nyje winscen, Nyje ré fan nyje minschen. Weer ûs livven ek su ny, Sunden wârdven lichst fan fry.

Februarius het xxviii deggen. Silers meye winters reste, Thûs tu blieuwen mut jerm leste. Lot men iertske surg mêr stân,

Mengwar scoe men better dwân.

Majus het xxxi deggen. As we tommelje oeuwer 't wetter Heuwe't slim en soms hwet better:

Su's de urâld ek as de sê, Soms fol kurje, soms fol nê.
January has xxxi days, New days, new wishes, New counsel of new men. Were our life eke so new, We should grow lightly free from sins.

February has xxviii days. Sailors may rest in winter, To stay at home must please them. If one let earthly sorrow more stand,

Many times we should do better.

May has xxxi days. .

As we tumble o'er the water

We have it bad, and sometimes somewhat better :

So is the world eke as the sea, Sometimes full of delight, Sometimes full of woe. 


\section{DIALECT OF SAGELTERLAND.}

From the Parable of the Prodigal Son. Winkler, Algemeen Nederảuitsch en Friesch Dialecticon, vol. i. p. 158 .

\section{LUKE XV.}

I I. Där was ins en mâenske un di hîde twêen sûne.

I 2. Un di jûngste fen do bêe quâd to sîn babe : babe ! räk mi mîn erfdêl. Do dälede di ôlde mon it him to un raet him wet him tokäm.

I3. Etter änigen degen pakte di jûngste fent sîn hêle erfskup bi'nunder un tôg wî̀ wei în en fraemd lond, un där brogde hi al sîu jêld un gôd ume med frêten un sûpen un quôd to liujen.

I4. Do hi nu sîn hêle fermûgen fernêled un sîn ganse erfskup fertäred hide käm där in det fraemde land en djûre tîd, en grôte hungersnôd, un hi mosde ôk hunger lide, ûmdet hi nix nên jêld môr hide ûm där brôed of wet ôrs fôr to kôpjen.

15. Wet skûl hi nu dwo? Arbeidje leste him nit, un wel wîl him ôk în sîn tjonst nîme? Dach käm hi bi'n bûr un där forhêrede hi sik bi. Di bûr saente him op sîn fêld ûm de swine to waerjen.

\section{NORTH-FRIESIC.-MORINGER DIALECT.}

Bendsen, Die Nordfriesische Sprache, p. 455.

Hörrwäjl ühsen nordfráshe Spräjke ài sö urdrick ás, ás de huchtjüshe an auser mörr üttbillet Spräjke, sö hêt'r doch Üttdrücke an Wijnninge nög, ám ausere sín Tögte dötlick mátódielen, wann' m's mãn tó brücken an rógt äujntówijnnen forstönt. Dãt aurs en Tung, dirr hám oller tó Shráftspräjke häwet hêt, Brãk faar sóck Urde hêwe mäujt, dirr auwersánnlick Ijnstãnde an Begrippe betiekne, ás lágt intósieën. Häi’r en iuttbrãt Shráft-an Baukewäsen häjd an faurtsêt, sö würd'r ock nög Shridd hüllen hêwe má auser iittbillet Spräjke, ás má de 
dãnshe, tjüshe, holläujnshe an ájngelshe, dirr nö áltemãle faale urdrickere sán.

\section{Translation.}

Although our North-Friesic tongue is not so copious as the High-German and other more finished languages, yet it has expressions and idioms enough to make clear one's thoughts to others, if one only knows how properly to employ and avail himself of them. As to the rest, that a tongue which has not come to be a written form of speech should be lacking in such words as indicate abstract ideas and conceptions is naturally to be presumed. If it had had and fostered a broad literary experience, and been used in books, it would have kept step with other polished dialects, like the Danish, German, Dutch, and English, which are all more copious.

\section{THE FRISIAN ISLANDS.}

Dialect of Föhr and Amrum.

Johansen, Die Nordfriesische Sprache, p. 193.

ST. MATTHEW'S GOSPEL, CHAPTER V.

I. Man diar hi det skööl Lidj siigh, ging hi ap üuibh an Berragh an siad ham deel, an sin Jüngarn tread hen tu ham.

2. An hi ded san Müs ap, liard jo an sâd:

3. Sâlagh san dönnan, diar geissalk âram san : at Hemmalrik as herrens.

4. Sâlagh san dönnan, diar surgi : jo skel treast wurd.

5. Sâlagh san a Gilasnan : jo skel a Eardark hâ.

6. Sâlagh san dönnan, diar hongri an tharsti eftar a Girechtaghâid: jo skel sat wurd.

7. Sâlagh san a Barmhartagan: jo skel Barmhartaghâid finj.

8. Sâlagh san dönnan, diar an rian Hart hâ : jo skel God se.

9. Sâlagh san a Freeshalkan : jo skel Gods Bearenkin het. 
ıo. Sâlagh san dönnan, diar am a Girechtaghâid vörfullacht wurd: at Hemmalrik as herrens.

Ir. Sâlagh san jam, wan a Minskan jam am man Wal spaati an vörfulgi an snâki allarhant Iaraghs jin jam, wan jo det leegh.

\section{WANGEROG. \\ The Lord's Prayer.}

Ehrentraut, Friesisches Archiv, ii. 57.

Ûz fôer in'e hémmel'! Dîn númme mî héilîg hî́len wêr. Dîn rîk kúmme. Dîn wil mî dain wêr up î́rden as in'e hémmel. Ûz díggelk brôed reik ûs dû́ullûng. Un fargive ûs ûz schîl, sâ as wî ûz schî́nêrs fargivet. Un fêr ûs nich in't farseiknis, man erléiz ûs fon dait quôed. Den dîn is daitrîk un djû krä̂ft un djû hếrelkeit in ếwîgkeit. Ấmen.

\section{SYLT.}

\section{PRODIGAL SON.}

Winkler, i. 94.

LUKE XV.

I I. En man hed tau dräänger.

I 2. En de jungst fan jam seid tö de faaðer : faaðer ! dö mi de diil fan dit gud, diar mi jert. En de faaðer diilet jam dit gud.

I3. En ek lung diar eeðer saamelt de jungst seen alles tö hop, en toog für wegh aur löıð, en diar braagt hi sin gud tö'n önt me fraanzin.

I4. Diar hi nü al sin gud fortiared hed, kam er en jüür tid aur dit hiile lönð en hi bigent nuad tö liiðen.

15. En hi ging hen tö en borger fan det sallef lönð, en förhüürt höm diar; en de stjüürt höm üp sin eeker om de swin tö jääten. 
H E L I G O L A N D.

Prodigal Son.

Winkler, i. 99.

LUKE XV.

I I. Diar wiar ianmâl'n man, de hîd tau jongen.

I2. De jongst fan jam said to herrem fâr : fâr! do mi det dêl fan't gôd wat mi tohiart. En da dêlt de ôl man jam det gôd.

I3. En ni long dar na sammelt de jongst sön alles't ôb en reist fîr over d'lun; da levved he fergnögt en brocht sîn gôd hendêr.

I4. Da he ne sîn gôd hendêr hîd wur alles so jür un det frem lun en da mos he hongere.

15. He ging hen na'n bûr, en de sand hèm üp sîn akker, de swîn to hodderen.

\section{SCHIERMON NIKOOG.}

PRODIGAL SON. Winkler, i. $45^{8 .}$

LUKE XV.

I I. D'r wier reis'n man, in di hiea twa jonges.

12. In iean fan har beiden, it wiea de jongste, sei tjin har heit: heit ! jeuw mi miin guued dot mi toekomt. In har heit deelde har't guued.

13. In körts d'r nooi dão't er olles bi'neeuwr forgare hiea, is er furtgiean nooi'n fraeimd laaun to, in der het er siin guued trôch brocht in'n kwaaid livven.

I4. In dão't hi't olle gerre fortãors hiea, koom'r huengersneud iin dot laaun in hi kriige gebrok.

15. Ik dão ging hi nooi dão juued to fan dot laaun in friegge har om werk; in jão juegene him werk in stjuersene him nooi har laaun to om har swiine to huueden. 


\section{Extracts from the Oera Linda Bok, English Edition, p. 2.}

Okke min svn-thissa boka mot $i$ mith lif ánd sêle wârja.

Se vmbifattath thju skêdnisse fon vs êle folk âk fon vsa êthlum.

Vrlêden jêr hảb ik tham ut-er flod hred tolik mith thi and thinre. moder. Tha hja wêron wet wrden; thêr thrvch gongon hja áfternei vrdarva.

Vmbe hja navt to vrlysa háb ikra vp wrlandisk pampyer wrskrêven.

Sa hwersa thu se erve, mot thu se $\alpha k$ wrskryva.

Thin bàrn alsa til thju hja nimmerthe wêi navt ne livma.

Skrêven to Ljuwert. Nêi Âtland svnken is thàt thria thîu sond fjower hvndred and njugon and fjowertigoste jêr, that is nei kersten rêknong that tvelfhundred sex and fiftigoste jêr. Hidde tobinomath Oera Linda. Wâk.

Ljawa ervnôma, vmb vsa ljawa êthlas wille ànd vmb vsa ljawa fridoms wille, thusând wâra sâ bidd:ik to jo, och ljawa ne lêt tha âgon ênis papekappe tach nimmerthe over thissa skriftane wêja.

Hja sprêkath swêta wirda : men hja tornath vnmárksêm an alles hwat fon vs fryas trefth.

Vmbe rika prebende to winnande sâ hêlath hja mith tha poppa kêninggar, thissa wêtath that wi hjara grâteste fianda send, thrvchdam wi hjara liuda to sprêke thvra vr fridom, rjucht ànd forstne plicht. Thervmbe lêtath hja alles vrdiligja, hwat fon vsa êthlum kvmt àd hwat thêr jeta rest fon vsa alda sêdum.

Och! ljawa, ik häv by tham et hove wêst. Wil wr-alda-t thjelda and willath wi vs navt sterik ne makja, hja skilun vs algâdur vrdiligja.
Okke my son-you must preserve these books with body and soul.

They contain the history of all our people, as well as of our forefathers.

Last year I saved them in the flood, as well as you and your mother; but they got wet, and therefore began to perish.

In order not to lose them I copied them on foreign paper.

In case you inherit them you must copy them likewise.

And your children must do so too, so that they may never be lost.

Written at Liuwert, in the three thousand four hundred and fortyninth year after Atland was submerged-that is, according to the Christian reckoning, the year 1256 . Hiddo surnamed Over de Linda. Watch.

Beloved successors, for the sake of our dear forefathers, and of our dear liberty, I entreat you a thousand times never let the eye of a monk rest on these writings.

They are very insinuating, but they destroy in an underhand manner all that relates to us Frisians.

In order to gain rich benefices they conspire with foreign kings, who know that we are their great enemies, because we dare to speak to their people of liberty, rights, and the duties of princes; therefore they seek to destroy all that we derive from our forefathers, and all that is left of our old customs.

Ah ! my beloved ones, I have visited their courts : if Wr-Alda permits it, and we do not show ourselves strong to resist, they will altogether exterminate us. 
Skrêven to Ljuwerd, acht hondied ànd thrju jêr nei kersten bigrip.

Liko tobinômath Ovira Linda.
Written at Liudwert anno domini 803 .

Liko, surnamed Over de Linda.

\section{Wr-AldA, p. I4I.}

Wr-alda was êr alle thinga, ànd nêi alle thinga skil er wêsa.

Wr-alda is alsa êvg and hi is vnendlik, thervmb nis thêr nau't buta him.

Thrvch Wr-aldas lêva warth tid and alle thinga bern, and sin lêva nimth tid àd alle thinga wêi.

Thissa sêka moton klêr ànd bâr makad wrda by alle wisa, sâ thàt hja-t an ôtherabithjuta ànd biwisa müge.

Is-t sâ fâr wnnen, sâ sêith man forther; huat thus vsa ommefang treft, alsa send wy en dêl fon $W r$ aldas vnendelik wêsa, alsa tha ommefang fon al et eskêpne, thach hwat angâ vsa dânte, vsa ainskipa, vsa gâst ànd al vsa bithänkinga, thissa ne hêra navt to thet wêsa.

Thit ella send fljuehtiga thinga tham thrvch Wr-aldas leva forskina, thach thêr thrvch sin wishêd saddane and navt overs navt ne forskina. Men thrvchdam sin lêva stêdes forthga, alsa ne mêi thêr nawet vppa sin stêd navt bilywa, thêrvmbe forwixlath alle eskêpne thinga fon stêd, fon dânte ànd ak fon thánkwisa.

Thervmbe ne mêi irtha selva ner eng skepsle ni sedsa, ik ben, men wel ik was.
Wr-Alda existed before all things, and will endure after all things.

Wr-Alda is also eternal and everlasting, therefore nothing exists without him.

From Wr-Alda's life sprang time and all living things, and his life takes away time and every other thing.

These things must be made clear and manifest in every way, so that they can be made clear and comprehensible to all.

When we have learned so much then we say further: in what regards our existence we are a part of Wr-Alda's everlasting being, like the existence of all created beings; but as regards our,form, our qualities, our spirit, and all our thoughts, these do not belong to the being.

All these are passing things which appear through Wr-Alda's life, and which appear through his wisdom, and not otherwise ; but whereas his life is continually progressing, nothing can remain stationary, therefore all created things change their locality, their form, and their thoughts.

So neither the earth nor any other created object can say, I am, but rather I was.

\section{LAws, p. 33.}

I. Ek fryas mot-a lêtha jeftha flyanda wêra mith aldulkera wàpne aser forsinna, bikvma ànd hândtêra mềi.

2. Is en boi twilif jer, sa mot-i tha sjvgunde dêi miste fon sin lêrtid vmbe rêd to werthande mitha wápne.
I. Every Frisian must resist the assailants with such weapons as he can procure, invent, and use.

2. When a boy is twelve years old, he must devote one day in seven to learning how to use his weapons. 
8. Annen kêning ne mêi navt ni lônger as thrê jêr kêning bilywa, til thju hi navt biklywa ne mêi.

I0. Is thi kêning thruch thene fyand fallen, sa mügon sina sibba âk nêi thêre êre thinga.

12. Therra tham strida mitha wàpne an hjara handa nekunnath navt forsinna and wis bilywa, thêrvmbe ne fochteth nêne kềning wápne to hantêra an tha strid.

Sin wisdom mot sin wápen wêsa and thju ljafte sinra kámpona mot sin skyld wêsa.
8. No king may be in office more than three years, in order that the office may not be perma. nent.

ro. If the king is killed by the enemy, his nearest relative may be a candidate to succeed him.

12. Those who fight with arms are not men of counsel ; therefore no king must bear arms.

His wisdom must be his weapon. and the love of his warriors his shield.

\section{Page 2r.}

Wr. Aldas gâst mêi màn allêna knibuwgjande thânk to wya, jâ thrju wâra far hwat jv fon him noten hàve, far hwat jv nith, àd fara hâpe thêr hy jo lêt an ànga tida.
To Wr. Alda's spirit only shall you bend the knee in gratitude -thricefold-for what you have received, for what you do receive, and for the hope of aid in time of need.

\section{Page 31.}

Alle frya bärn send a êlike wysa bårn, thêrvmbe moton hja âk êlika rjuchte háva, alsa blyd vpp-àt land as vpp-àth $\hat{e}$, thàt is wêter, and vp ella thàt $W r$. Alda jefth.

2. Allera mannalik mêi-t wif sinra kêsa frêja ànd ek toghater mêi efter hjra helddrvnk bjada thêr hju minth.

6. Ek thorp skil en hêmrik häva nêi sina bihof ànd thêne grêva skil njvda that alra ek sin dêl bidongth and god hald, til thju tha a fiter kvmmande nên skäde navt ne lyda ne muge.
All free-born men are equal, wherefore they must all have equal rights on sea and land, and on all that Wr. Alda has given.

Every man may seek the wife of his choice, and every woman may bestow her hand on him whom she loves.

Every village shall possess a common for the general good, and the chief of the village shall take care that it is kept in good order, so that posterity shall find it uninjured.

NoTE.-The indication of vowel quantity in the printed text of the O. L. B. is very arbitrary and incorrect. 


\section{GLOSSARY. \\ (TO THE OLD FRIESIC READING LESSONS.)}

$a$, prep. w. dat. and acc., in, on, with, to, by.

$\hat{a} c$, aeck, $\hat{a} k$, conj., also, but.

acht, card., eight.

achtunda, ord., eighth.

$a f f=o f$.

aft, adj., own, legitimus.

aga, hâga, v. praet. pres., to have to.

âge, n., eye.

$a l$, adj., all, every.

aldeerom, conj., therefore.

alderto, adv., thereto, in addition thereto.

aldes $=$ al thes.

algâdur, adv., altogether.

aldus, adv., thus.

al with thet (conjunctive phrase), since, inasmuch as.

alêna, adv., alone.

allermonîck=allera monna êk.

allyne, alêne, alêna, adv., only.

alomme, alumbe, prep. w. acc., during

(follows the noun governed).

alrêc, aller $a-\hat{e} k$, indef. pr., each. alsû, als, conj., so, also, as, when.

alsâre =alsâ ther.

$a l_{2} \hat{0}=a l s \hat{a}$.

an, prep.w. dat. and acc., in, on, to, by. ana, anna, prep. w. dat. and acc.,

to, into.

and, ende, anda, conj. and.

and, prep. w. dat. and acc., in, on, to.

and $a=$ anth .

ander, see other.

andere $=$ anthere.

andlofta, ord., eleventh.

ane, oni, prep. w. dat. and acc., without.

angl, engel, m., angel.

antasten, Mid. Lat. and Ital. tastare, to obtain.

antes $=$ and thes.

antuintech $=$ and twintich. arcke, erke, f., ark.

aerst, ârst, see êrost.

arve $=$ erve.

âsiga, âsega, m., judge.

aslâ, str. v., to strike.

asta, adv. and n., aster, east.

ayn, ein, êgin, adj., own.

bâm, m., tree.

ban, $\mathrm{n}$., permission.

bêde, see bêthe.

behêllde, see bihalda.

bêken, n., beacon fire.

belêva, bilîva, str. v., to remain, to be permitted.

bênete, n., coll. n., bones.

bêre, f., bier, barrow.

berch, m., mount.

bern, n., child.

berna, barna, burna, w. v., to burn.

ber(e)skinse, adj., nudipes, barefooted (lit. bare-shinned), hence apertus, open, public.

beschirmen, biskirma, w. v., to protect.

besit, n., property.

besitter, m., possessor.

besittinghe, f., possession.

beslûta, see bisluta.

bête, f., fine.

bêthe, num., both.

beva, w. v., to tremble.

$b i$, prep. w. dat. and instr., by.

bifâ, str. v., to cover, to fall to, 3 d pers. s. pres. bifêth, pret. part. bifangen.

bifara, adv., before.

bifclla, byfella, str. v., to command, enjoin.

bigade, w. pret. of bijenna, to begin. bihalda, behalda, str. v., to retain, to refuse. 
$b i j$, Dutch form of $b i$.

binda, str. v. to bind, fetter.

binna, prep. w. dat., within.

birâvja, w. v., to rob.

bire $=$ bi there.

bisêka, w. v., to deny.

bisetta, bisitten, w. v., to possess.

bisîa, str. v., to behold.

bisitta, str. v., to dwell.

biskirma, bischirma, w. v., to protect.

biskriva, str. v., to describe.

bislatta, str. v., to include, shut in.

bistrida, w. v., to oppose.

biada, str. v., to bid, command, pret.

(e) bâd.

blâ, str. v., to blow.

blêrem $=$ blê $\mathrm{er}$ him.

blôd, n., blood.

blôdelsa, m., bloody wounding.

blôdig, adj., bloody.

bod, n., commandment.

$b \hat{b} k$, f. and neut., book.

bonna, str. v., to prescribe by law.

bôte, f., mulct.

bova, prep. w. dat., above, over.

breka, str. v., to break.

brenga, brensza, branga, w. v., to bring, pret. brôchte.

brân, adj., brown.

bar, in., neighbour.

burch, f., town, urbs, oppidum.

burna, see berna.

bata, prep. w. dat. and acc., without, outside.

bata, conj., but.

$b y=b \hat{\text {. }}$.

bynima, binima, str. v., to take.

bysetta, see bisetta.

bytila, bitila, w. v., to obtain.

camp, kamp, komp, m., battle, duel. clach, see klath.

clipskelde, f., debt, tribute, censio, ringing gold.

coma, see koma, kuma.

$c o n=k e n$, kin.

concordera, w. v., to agree.

criose $=$ kriose, cross.

Cristen, adj., Christian.

crôna, see krôna.

cade, pret. of kunna.

cuma, see koma.

curd kund, adj. known. dae, see thâ, thi.

dân, part. done.,

dan, danen, thenne, adv., then.

$d \hat{a} r=t h e ̂ r$.

dat $=$ thet.

dâw, m., dew.

deer, see thêr.

deerom, conj., therefore.

dega, see dî.

dêla, w. v., to deliver, hand over.

der $=$ there.

dêth, pres. sing. of $d \hat{u} a$.

$d i$, see $t h i$.

$d \hat{\imath}$, dei, m. day.

dijjen, pres. pr., he.

dik, m., dyke.

dir $=$ there.

dôch, thâch, conj., though.

doet, dâd, dâth, adj., dead (as a noun, death).

dôm, m., doom, judgment, command.

dômliacht, adj., bright, clear.

dorsticheit, f., audacity.

drockten, m., lord.

dua , w. v., to do, make, perform ;

pret. dêde, part. dên, dân.

$d w a e n=d u a$.

dwalicheit, f., error.

$d y=$ thi.

$d y o=t h i u$, used erroneously some-

times for fem. acc. tha; e.g., dyo

besittinghe, for tha b., \&c.

$d y r=$ ther.

êdel, êthel, adj., noble.

eder, conj., or.

eenbeet, adj., single.

eenferd, adj., single.

eetmel, n., half a day of twenty-four hours.

efter, adv. and prep. w. dat. and acc., after, through.

eg, f., sword.

egâdurad, see gâdurja.

êgen, ein, adj., own.

ehêten, see hêta.

eifna, w. v., to level.

ellefta, andlofta, ord., eleventh.

$e l k$, eelk, êk, indef. pr., each.

emênad, see mêna.

$e ̂ n$, adj., card. and indef. pr., a, one, alone, only.

ende, conj., and. 
ênich, adj., any.

ense, enze, f., ounce, denomination of a coin.

er, hiri, or, poss. pr., their, her.

er, pers. pr., he.

$\hat{e} r$, prep. w. dat., before up to.

êr, adv., formerly.

êrja, w. v., to honour.

êrost, ord., first.

erthe, irthe, f., earth.

erve, arve, n., inheritance.

ervja, w. v., to inherit (êgen ervede vrouwe, a wife with independent inheritance).

eskêpen, see skeppa.

eskrivin, see skrîva.

espen, adj., aspen.

e-sueren, see swera.

et, prep. w. dat., to.

ewrocht, see werka.

falla, str. v., to fall.

fan, see fon.

fana, fona, m., banner, standard (mit een opriucht fana, openly).

fand, see finda.

fâra, str. v., to carry, proceed, go.

feder, m., father.

felo (Germ. viel), n., much.

fella, str. v., to pay, be fined.

fenne, m., pasture-land.

ferd, fretho, m., a certain mulct.

festa, w. v., to fast.

fethm (fethom, fethem ?), m., fathom. fia-êth, m.. money oath (perhaps one sworn upon a coin marked with a cross, or one that involved a pecuniary liability).

fiarda, ord., fourth.

fiurtiensta, fiuwertênsta, ord., fourteenth.

$f \hat{f} f$, card., five.

fifta, ord., fifth.

fiftînda, ord., fifteenth.

fîftîne, card., fifteen.

fili, adj., unencumbered, unappropriated.

finda, str. v., to find, pret. fand. fîr, adv., far (comp. fî̀:or, farther). firja, w. v., to hallow.

fisk, m., fish.

fiuchta, str. v., to fight.

fiund, m., enemy. fiuver, card., four.

fiuwertich, card., forty.

fiuwertînda, ord., fourteenth.

flask, n., flesh.

flât, see fliata.

fli a, str. v., to flee.

fliata, str. v., to flow.

flôd $(e), \mathrm{n}$. , flood.

foerlyosa, forliusa, urliasa, str. v., to lose, forfeit.

folgja, w. v., to follow.

folk, n., folk, people.

folla, fullja, fella, str. v., to compensate.

fon, fan, prep. w. dat., of, from.

forbulga, str. v., to be wroth.

forestân (Germ. verstehen), str. v., to understand.

for-gunga-gân, urgunga. str. v., to go away.

fori, prep. w. acc., for.

fork(e), f., fork, earth fork.

forma, ord., first.

forslâ, urslâ, forslâen, str. v., to destroy.

forth, adv., then, thereupon.

$f \hat{t} t, \mathrm{~m}$., foot.

frâna, m., magistrate, lord.

Fresa, m., Frisian.

fretho, frede, m., peace; also a mulct.

frî, adj., free.

frîdôm, m., freedom.

Frisa, m., Frisian.

gâ, n., vicus, town, district.

gâdur, adv., together.

gadurja, w. v., to gather.

gêla, to hunt.

gelde, see jelda.

gelden, adj., golden.

gelyck, gelik, adj., like, adv. phrase, desgelyken, likewise.

gers, gras, n., grass; $\mathrm{xxx}$ fethma tô gerse, thirty fathoms meadow land.

gersfalle, gersfelle, f., a falling to the ground; lidse gersfelle, to lie as a thing neglected on the ground - to be overlooked.

geva, see jeva.

$g h a e=g \hat{a}$.

glâ, glia, w. v., to glow. 
glêd, f., brand.

God, m., God.

gobd, n., property, goods.

godilike, adv., honourably.

goet $=g \hat{o} d$.

grât, adj., great.

grêne, adj., green.

gued $=g \hat{o} d$.

gunga, unga, gân, str. v., to go.

gunth=gungath.

hâch, adj., high.

hâchere, hâgere $=(h)$ ach er.

halda, str. v., to hold, keep; pret. pl., hildon.

half, adj. and n., half.

handschôch, m., (Germ. handschuh), glove.

hanzoch, hensich, adj., subject.

hârra, hâra = hiara, hira.

haudlesne, haudlase, hâvedlesne, f., capitis redemptio, ransom for a

forfeited head (life).

have, heve, f., property, possessions. hebba, w. v., to have; pret. hede.

hede, see hebba.

hef, n., sea.

hêl, adj., whole, sound, solid.

hêlich, m., saint.

hêlig, adj., holy ; tha hêligum, for pious uses.

helm, m., helmet.

helpa, str. v., to help.

hêra, hêr, m., lord.

hêra, w. v., to belong.

heerd, hirth, m., hearth, home.

her(e)ferd, hiriferd, f., campaign.

heresceld, hiriskeld, m., corps, squadron.

here, hiri, m. and neut., army, host. herne, f., corner; kuma et thera fjuwer hernena hwelik mith tian merkon, to come to each of the four corners of the house (which was robbed) with ten marks; a periphrasis for "the mulct for burglary (when confessed) is forty marks."

hêroch, adj., obedient.

hêrskipi, n., rule, sway, ownership, control.

herte, see hivte.

hêta, str. v., to be called, named. hêthen, adj., heathen.

hêththere =heth $(\mathrm{ma})$ thếr.

heve, see have.

$h i$, pers. pr., he, neut. hit, dat. him, acc. hine, hini, pl. hia, gen. hiva. hille, f. and $\mathbf{n}$. , hell.

himelsch, himulisk, adj., heavenly.

himul, m., heaven.

himulrîk, n., heaven.

$h \hat{\imath} r$, adv., here.

hîrop, adv., hereto.

hirte, f., heart.

hirthstidi, m. and f., hearth.

hlaka, w. v., to laugh.

ho, $h u$, adv., how.

$h \hat{c} c$, hwelik, indef. pr., which.

Hochenzie, f., "Oho" town.

hoek $=h w e \hat{k}$, hwelikk.

hof, n., court, domus, aula.

hond, f., hand.

hôp, m. (Engl. hoop), ring, band.

$h o \hat{r}$, n., whoring.

$h \hat{t}$, hwat, indef. pr., what.

hrôpa, str. v., to call to, upon.

hunder, hundred, card., hundred.

hunig, n., honey.

has, n., house ; thet has thera liuda, let the house be the people's ; i.e., escheat to the state.

huslotha, m., house-tax.

hwande, hwant(e), conj., since, because, for, adv., when.

hwasâre $=h$ was $\hat{A}$ there.

hwas $\hat{0}$, indef. pr., whoever.

hwêk, hwelikk, indef. pr., whoever.

hweerom, conj., why.

hymelrych, see himulrik.

hyrop, see hîrop.

$i d=h i t$.

idle, adv., idly, in vain.

in, prep. w. dat. and acc., in, to.

inghel, see angl, engel.

ingunga, ingân, str. v., to enter.

inna, prep. w. dat. and acc., in, into.

innâre =inna there.

inroste, m., insider.

inur, inoer, prep. w. dat. and acc.,

at, in, over.

irthrik, n., earth.

irthbivinge, n., earthquake.

$i s$, see wesa.

Israhêlisk, adj., Israelite. 
ister $\alpha=$ isther $a$.

ivinhâr, adj., equally high.

ivinkerstena, m., fellow-Christian.

ja, str. v., to confess, admit.

jahwelik, indef. pr., every, every one. $j \hat{a} r=j e ̂ r$.

jef, conj., if.

jeftha, conj., or.

jeld, n., mulct, wergeld.

jelda, gelda, str. v., to pay; sub. gelde, jelde.

jen, demons. pr., he ; dijjen, he who, that one.

jêr, n., year.

jerde, f., rood; jerd-îk, every rood.

jerja, w. v., to covet.

jerne, adv., gladly.

jeva, str. v., to give.

joed, a weak pret. of jeva.

Jôthane, adj., Jewish.

karfestere, m., one who observes fasts. kêla, w. v., to expiate (lit. refri $i$ gerari).

kest, f., privilege, right.

ketha, w. v., to order.

keysar, m., emperor.

kinig, kining, m., king.

klâth, clâth, n., clothing.

koep, kâp, m., purchase.

kon, ken, n., kin.

koning, m., king.

kriose, krus, n., cross.

krône, crône, f., crown.

kumia, koma, str. v., to come.

kunna, v. præt. pres., can, to be able to, posse.

kynd, kind, n., child.

$l a ̂ f$, n., leaf.

land, lond, n., land.

langhe, adv., long.

lêda, w. v., præt. lâtte, to lead, lead forth.

lega, lidsja, w. v., to lie.

lêra, w. v., to teach.

lêta, str. v., to let.

leter, adj., later, last.

lethoga, w. v., to free, save.

liaga, str. v., tolie; pres. $3 \mathrm{~d}$ sing.lith. liane (liave), f., wife.

libba, w. v., to live.

$l \hat{\imath} k$, adj., like.

likke, adv., like, in the same manneras. liode, m., plur. n., people.

liodkest, f., legal right, privilege.

liodmerk, f., folk's mark, a coin.

$l o k, \mathrm{~m}$., lock of hair.

lond, land, n., land, country.

londriucht, n., statute.

long, lang, adj., long.

$l y f, l i f$, n., life.

ma,me, men, indef. pr.,one, French on. $m a c h=m \hat{\imath}$.

macht, mecht, f., authority.

manniska, m., man.

mannesklîk, adj., human.

mâr, adj., greater.

mâstere, m., master.

$m e=m a$.

melok, f., milk.

$m e n=m a$.

mêna, w. v., to bring back.

meneska, see manniska.

mênêth, m., false oath.

mer, mar, conj., but.

merk, f., mark.

mêt $=$ ma hit.

mêta, w. v., to meet, pass.

mey $=$ mith.

$m \hat{\imath}, m_{i} i, \nabla$. præt. pr. may; pl., mugun.

minnja, w. v., to love.

minscha, m., man.

mith, mithi, prep. w. dat., with.

môder, môther, f., mother.

mon, man, m., man.

monig, adj., many, many a.

monslaga, m., murder.

morth, n., murder.

mucht $=$ machte.

mugun, pl. of $m \hat{\imath}$.

mure, f., wall.

myn, mîn, poss. pr., my, mine.

mynscha, manniska, m., man.

$n \hat{a}$, nei, prep. w. dat., after, accord-

ing to.

nacht, f., night. ।

naet $=$ nâwet.

nama, noma, n., name. 
$n \hat{a} s=$ ne was.

nâthe, see nêthe.

nâwet, näut, adv., not.

ne, adv., not.

ne, conj., though, but if ; hit ne sê, but if it so be.

nech thêre $=$ ni hêtth $(m a)$ thêre.

nêd, nâth, f., trouble, necessity, misfortune.

nêdwere, f., self-defence.

needver, see nêdwere.

neil, neyl, m., nail.

nêl $=$ ni wil.

nêllath $=$ ni willath.

nêt $=$ ni wêt.

nên, adj., no, not any.

nêthe, f., kindness.

neyl, see neil.

nicht $=$ nâwet.

nîga, hnîga, str. v., to incline to, be obedient to.

nima, nema, str. v., to take.

nimmen, nymmen, indef. pr., nemo, no one.

njugunda, ord., ninth.

noma, see nama.

north, adv., north.

$n u$, adv., now.

nyma, see nima.

oeck $=a c$.

oen $=a n$, on.

oencomma, onkuma, str. v., to ac.

quire, obtain.

oenfalla, str. v., to fall.

oer $=$ ôther, also $=o r=h i r i$.

oerlef, orlof, n., permission.

of, prep. w. dat., of, from.

of, adv., out.

of, jef, conj., if.

ofwinna, str. v., to take away.

oho! interj., oho!

olt, ald, adj., old.

om, see umbe.

om, ethma, m., spirit.

on, prep. w. dat. and acc., in, on, into.

onayn, unein, adj., improper.

onbijen, m., beginning.

ondwarde, n., answer, response.

ondwardja, w. v., to answer, make

full account.

ongost, angst, n., anguish.

onriucht, adj., wrong, wrongful. ont, prep. w. acc., until.

openbaer, epenbêr, adv., openly. opgaen, str. v., to go, come on. oppa, opa, prep. w. dat. and acc., against, upon.

opriucht, adj., raised on high, waving. or $=$ hiri, her.

ord, m., spear.

ôron $=\hat{o}$ theron.

other, ander, ord., second, other.

ova, prep. w. dat. and acc., and adv., over, upon, with reference to; fon ova to ata, from one end to the other.

overhôr, n., adultery.

palmere, m., pilgrim, palmer. penning, panning, m., penny. pilegrim, pilugrim, m., pilgrim. plichtich, adj., charged with the oversight (followed by the genitive).

porte, f., gate, portal.

pund, pundt, n., pound.

$r a d$, adj., red.

râd, raed, rêd, m., counsel.

râf, n., robbery.

$-r e=e r$, pers. pr., he.

rêden(e), f., legal petition, lis, causa. rêdjeva, rêdja, m., judge.

rêne, adj., pure.

rêsza, rêka w. v., to pay, deliver to ;

præt. râclıte.

rib, n., rib.

riucht, $\mathrm{n}$., law, system of laws.

riucht, adj., right, proper.

riuchta, w. v., to right one's self,

legally purge.

riuchter, m., judge.

râmfâra, m., pilgrim to Rome.

$s \hat{a}$, conj., so, as, than ; frequently a mere expletive.

$s \hat{a}(s \hat{b}) h w a-s \hat{d}$, neut. $s \hat{a}-h w e t-s \hat{a}, '$ 'in-

def. pr., whosoever, whatsoever.,

salt, adj., salty.

sanct, sankt, m., saint.

sant, see sanct.

sched $a=s k \hat{d} d a$.

schel $=$ skil. 
schyldich, see skeldich.

scillad, see skila.

scilling, schilling, skilling, m., shil-

ling.

scône = skône.

scôp, see skeppa.

scrioun, pret. part. of skriva; scrioun riucht, lex scripta.

$s \hat{e}, \mathrm{~m}$., sea.

se, pers. pr., nom. and acc. pl., they,

them (usually enclitic).

sêburch, f., dike.

sega, sedsa, w. v., to say, pret. seide. sel=skel, skil.

seel, sêle, f., soul.

self, selva, selwa, demons. pron. and

adj., self, ipse, same.

semin, adv., together.

sêna, w. v., to placate, appease,

reconcile.

sendeboda, m., messenger, nuntius.

sexta, ord., sixth.

sextech, sextich, sexthech, card.,

sixty.

seyd, seyt, preterits of sega.

sia, str. v., to see.

sick (Germ. sich), reflex. pr., himself,

herself, itself, \&c.

sîde, adv., downwards.

sigunda, sjugunda, ord., seventh.

sin, m., sense.

sin, syn, poss. pr., his, their.

sinnen $=$ sind.

sith, m., associate.

sitter, m., possessor.

skathja, skathigja, w. v., to injure.

skêda, skêtha, schêda, w. v., to de-

part, be separated from.

skeld, m., shield.

skeldich, schyldich, adj., bound, necessitated.

skeppa, str. v.. to create, pret. skôp. skila, v. præt. pr., shall ; pret. skolde,

pres. $2 \mathrm{~d}$ sing. skalt, pl. 1st pers.

skilu(n), Mid.-Fris. scillad, schellet.

skilling, m., shilling.

skipnese, f., form, shape.

skippere, m., creator.

skône, skêne, adj., lovely.

skrîva, str. v., to write, enact, pret.

skrêf.

slachte, m., race.

slêpa, w. v., to sleep.

so, conj., so. sogenja, somnia, w. v., to collect, gather together.

somnia, see sogenja.

sonder, sunder, prep. w. dat. and acc., without.

sône, f., propitiation, atonement.

Sonnendî, Sunnandei, m., Sunday.

sonu $=$ sunu.

spada, m., spade.

spîri, spêre, n., spear.

spreka, str. v., to speak.

spreke, f., speech, complaint, loquela.

stal, m., standing.

stâp, adj., high.

stathul, adj., firm, solid.

sted, stid, m. and f., place.

stên, m., stone, rock.

stêruen, adj., stone, of stone.

stera, m., star.

stêra, w. v.. to provide for.

sterva, str. v., to perish.

stherekhof, n., churchyard.

stid, see sted.

stifne, f., matter, status, conditio.

stifta, w. v., to construct.

stîga, str. v., to rise.

still, adj., still.

stôl, m., sedes, status, condition : thet alle Frisa an fría stôle bisitte, quod omnes Frisones in libera sede consistant.

stonda, str. v., to stand; pret. stôd. stôr, n., much.

strête, f., street, way, road.

strîd, n., combat.

suera, swera, str. v., to swear, make affirmation.

suertnesueng, swartaswing, m., a capital crime.

suêt, see swêt.

sumur, m., summer.

sunnandî, see sonnendi.

sunne, f., sun.

sunu, m., son.

suther, adv., south, southwards.

suther, suthern, adj., southern.

swêt, m., sweat, perspiration.

swilith, see tôswella.

$s y=s \hat{e}$.

syn, see sîn.

synnen, Mid.-Fris. for send.

tâle, f., complaint.

tauw, tow, n., tool. 
tefle, f., table.

tegôtha, m., tithes.

têr $=$ thêr.

ter $=$ there.

têken, n., sign.

testamentar, m., executor.

thâ, adv. and conj., then, when, than, or.

thattêr, indef. pr. neut., whatever.

thenna, thenne, adv., then.

ther, rel. pr., who, which.

thêr, adv., there.

thêrre $=$ ther thêr.

thes te, adv. phrase, so much.

thet, conj., that.

thette-thet hi.

thetterne = thet er thene.

thi, thiu, thet, dem. pr., the, acc. mas. thene.

thi, see $t h u$.

thiade, f., people.

thianja, w. v., to serve.

thin, poss. pr., thy.

thing, tins, n., thing.

thingath, tingath, m., suit, process.

this, thes, thet, dem. pr., this.

thiuvethe, f., theft.

tho $\hat{0}=$ to tha.

tho $\hat{\theta}=t \hat{\theta}$.

tholja, w. v., to suffer.

thornen, adj., thoruy.

thrê, card., three.

thredda, ord., third.

threddinda, ord., thirteenth.

thritich, card., thirty.

thruch, prep. w. acc., through.

thu, pers. pr., thou, dat. thi.

thura, v. præs. pr., to have to, pret. thorste.

$t i$ for thi, dat. of thu.

tian, card., ten.

tianda, ord., tenth.

til, prep. w. dat. and instr., to ; til

thiu, in order that.

tingad, see thingath.

timber, pl. n., buildings.

tiuch, n., testimony.

tjenstman, tyenstmane, m., vassal.

$t 6, t i, t e$, prep. w. dat., to.

tobreka, str. v., to break in pieces.

tocgaera, adv., together.

togta, thochta, m., thought, mind.

tôsemine, adv., together.

toswella, str. v., to swell, roll. tsyurke, tsierke, kerke, f., church.

$t u$, see thu.

tuiwald, adj., twofold, double. turf, m., turf.

tuybeet, twibête, adv., doubly fined, to the extent of a double fine. $t w a$, card., two, gen. pl. tûtra; $a$ twîra wegena, double.

tweer, twêne, card., two.

tuêne, see tweer.

twîa, num. adv., twice.

twijeld, n., double compensation.

twilifta, ord., twelfth.

twintich, ord., twenty.

twintigosta, ord., twentieth.

tyd, tidi, f., time.

umbe, om, prep. w. acc., around.

umbibur, m., fellow-citizen, pl. ulteriores vicini.

und $=$ and.

undfâ, str. v., to receive.

unfrethmon, m., belligerent man.

unga, gunga, str. v., to go.

unjêrig, adj., minor.

unviucht, adj., false, wrongful.

unskeldech, adj., innocent.

untfa, str. v., to take, receive.

unwis, adj., uncertain.

$u p$, adv. and prep. w. dat. and acc., up, upon.

ur, prep. w. acc., over, with reference to.

urbiada, str. v., to forbid.

urjelda, str. v. to pay, subj. urgulde. urjeva, str. v., to give, grant, yield, concede.

urswera, str. v., to swear.

urtîa, str. v., to pay, subj. urtêge.

$\hat{u s}$, dat. and acc. pl. pers. pr., us.

use, poss. pr., our.

ûta, conj., moreover.

ûta, adv., out.

athwysing, utwising, m., instruction, iujunctiou.

atroste, m., outsider.

$v a n=f o n$.

verbeteren (Dutch verbeteren), w. v.,

to increase.

verbeteringe, $\mathrm{f}$., rectification.

verkôpen, urkấja, w. v., to sell. 
vess $a=w e s a$,

vinden $=$ find $a$.

voermund, m. (Germ. vormund)

trustee.

voranderen, w. v., to alter.

vormelden, urmeldja, w. v., to en-

join, announce.

vormêren, w. v., to increase.

vorvesselen, urwixlia, w. v., to ex-

change.

vronde, friond, m., friend, protector.

vrouw, frôwe, f., wife.

wach / interj., alas! woe!

Wachenzie, f., "Woe" town.

waer, for was.

waer $=h w e ̂ r$, adv., where.

$w \hat{a} k a$, w. v., to awake.

wald, f., force, violence, wrong.

wan, want $=$ hwande.

wapeldêp, wapuldêpene, f., submersion.

warf, werf, m., stronghold, place of

deposit, assembly.

warlâs, adj., unprotected.

weddja, w. v., to give satisfaction,

make atonement for.

wegk, m., car, vehicle.

$u e i, w \hat{i}, \mathrm{~m}$., way, manner, road; gen. wiges.

weid, see wia.

wein, m., wain, waggon.

wend, m., substance.

wépen, n., weapons, arms.

weer for was: subjunctive errone-

ously used for indicative.

weerrêka, w. v., to return, give back.

wêra, w. v., to defend.

werd, see word.

uiere, f., property, possessions.

werf, see warf.

wergja, wirgja, w. v., to strangle.

weerjân, withirjeva, str. v., to give up

werka, w. v., to work, make ; pret.

part. ewrocht.

vếron, see wesa.

werp, probably for warf.

werrild, see wrald.

wertha, str. v. (aux.), to be.

wesa, str. v. (aux.), to be, pres. $3 \mathrm{~d}$ sing.

$i s$, pl. send, pret. s. was, pl. wêron.

uêse, com. gen., orphan.

wesseling, wixle, n., exchange.

west, adv. and n., wester, west. wetir, m., water.

weyd, pret. of wia, wiga.

$w i$, pers. pr. pl., we.

$w \hat{\imath} a, w \hat{\imath} g a$, w. v., to hallow.

wide, widue, f., widow.

$w \hat{f} f$, n., wife, woman.

wige, see wei.

wîlâs, adj., unconsecrated.

wild, adj., wild.

willa, w. v., to will, pret. pl. wel-

don, wolden.

willa, m., will, pernission, agreement. wind, m., wind.

winna, str. v., to win, gain.

winter, m., winter.

wird, werlh, adj., worth.

wird n., provision, injunction, com-

mand.

wirgja, see wergia.

$w \hat{\imath} s$, f., manner, wise.

wis, adj., wise.

wita, v. præt. pres., to know.

with, prep. w. acc. and instr., to, against.

with $a=$ with tha.

withene = with thene.

withêth, m., solemn oath, in reliquiis juramentum.

withir, prep. w. acc., against.

withstonda, str. v., to withstand, contend.

wolken, n., clouds, welkin.

word, n., word, command, permission.

wôstene, f., wilderness.

$w v^{*}=u r$.

wrald, f., world.

wrgunga, wragaen, str. $\nabla .$, to be destroyed.

wrstonda, str. v., to outstand, outstay.

wrwyeldelyk, urwaldelike, adv., violently.

$w s=\hat{u} s, \hat{s} e$.

wunde, f., wound.

wyeld $=$ wald.

$w y f=x \hat{\imath} f$.

wysa, wîsa, w. $\nabla$. , to show, indicate.

yâr, jêr, n., year; tô eren yâren

komen, to come of age.

$y s=i s$.

$z y n=\sin$. 


\section{N D E X.}

\section{(T'he references are to the Sections.)}

$a, 3$.

$a-, 145$.

$-a, \mathrm{x} 46$; themes, 55 ; as a subjunctive termination, ${ }^{1} 3^{8}$; gender of nouns ending in, 48.

a, 9 .

albreviation, of the pronoun, 96, 97 ; of various words, 40 ; of nouns in composition, $140^{\circ}$; of adjectives in comparison, 84 .

ablative, dative used as, $15^{8}$.

ablaut, defined, 42 ; verbs, $x$ Iо.

accent. $4 \mathrm{r}$.

accusative, cognate, I78; syntax, I8r, $182,183,186,187$; prepositions with, 193 ; preposition with accus. and dat., I95; prepositions with accus. and instrumental, I97 ; double, 187.

âch, $\mathbf{x} 26$.

active voice, I04, and see the verbal paradigms.

adjective endings, $\mathrm{x} 48$.

adjectives, $72 \mathrm{ff}$.; syntax, r63-167; declension, 73-75; comparison, 79; few to compare, $8 \mathrm{I}$; with genitive, I63; with dative, $164, x 65$; with the article, 72 .

admit, to, syntax of, I8r.

adverbs, 202 ; comparison of, 86 ; numeral, 90 ( 1 and 3) 92 (5) ; formation of, I49; with comparative endings, 82 ; pronominal, 102; negative, 202; of place, 149 (3).

adverbial phrases and expressions, 99 (3), I49.

ae, 19.

affirmation, particle of, 202 (4).

âge, declined, $6 \mathbf{r}$.

agent, forms indicating, 48 (ז, e.). $a i$, I $_{5}(9)$.

alliteration, 206-209.

Amrum, dialect of ; th in, 34 ; "father" in, 64".

-an, plurals in, $57(x)$; theme of weak declension, $6 \mathrm{r}$.

-and, $\mathrm{x} 46$; active participle in, 190. Anglo-Saxon, letters compared with

Friesic: see under the various

letters in Part I. ; gemination, 23

(4) ; vocalisation in suster, \&c., 28

(6) ; gender, 47 ; double accusative, I86.

anomalous nouns, 67; verbs, 139.

answering, syntax with verbs of, I79.

apocope, 23 (3), 43, II9.

apodosis, introduced by $s \hat{a}, 200$.

-ar, plurals in, 57 (I); -ar and -er inserted in nouns, 57 (4).

are, declined, 6r.

Askja, to ask for, syntax, $x 86$.

aspiration, loss of, $32(\mathrm{I})$; in the pro-

noun, 97 ; in the verb, 116 ; in

the adverb and particle, Io2.

aspirated liquid compounds, 23 (I).

assimilation, in verbs, 116 .

ate, $64^{*}$.

-ath, 147; gender of nouns ending in, $48(x)$.

atj, $64^{*}$.

au, 16.

auxiliaries, 108, 109, 126 ; arrangement of in sentences, ${ }^{2} 5^{2}$.

$b, 3 \mathrm{x}$.

bârg, 27 (3).

barnsdom, 25.

be-, bi-, 145 .

bed, 27 (3).

been, 25.

bera, syntax of, 184 . 
bereave, syntax of, 182 .

bern, declined, 55 .

bêthe, declined, 92 .

bidding, syntax with verbs of, 179 .

bifel, 27 (3).

bik, 27 (3).

boarstje, 25 .

boast, to, syntax of, 180 .

Brechung, 44.

breka, syntax of, 185 .

brik, 27 (3).

bring, 27 (3).

Brokmer Recht, plurals in, 57 .

burch, declined, 66.

büüg, 27 (3).

c, 2 (2), 36

cardinals, 87.

$c h, 2(3), 3^{8}$; for $f, 3^{I}(4)$; for $g$ and $k, 3^{8}(7)$; for $h, 39$.

coming upon, syntax with verbs of, I79.

comparative, 79-86; in ordinals, 89 ; $t h \hat{a}$, than, and $s \hat{b}$ used after, $\mathbf{x} 66$.

comparison, 79 ; irregular and defective, 85 ; double, 82 ; of adverbs, 86.

compensation, 45 .

complain, of, to, syntax of, 182 .

composition, $140 \mathrm{ff}$.; of verbs with

adverbs and prepositions, I4I ; nouns in, I40; of adjectives with nouns, I42; particles changing meaning in, I43; defining words in, 144 .

conjugation, IO7; first, or strong, IIo ; remarks on, II6-I25 ; second, or weak, 128 ; remarks on, $130-13^{8}$. conjunctions, I99; with subjunctive, 201.

consonants, $22 \mathrm{ff}$.

contraction, 9, 13, 15, 27 (4), 74, 84; of pronouns, 96, 97 .

controlling, syntax with verbs of, 179. conversion of a guttural into a palatal, 37 .

$d, 32$ (2); euphonically inserted, 32 (4) ; omitted from participle, 124 ; added to preterit participle in Modern-Friesic, I9I (3).

$-d, 149$ (3).

$-d a,-t a, \mathbf{I} 48$.

daere, 35 .

dan, 35 .

dat, 35 .

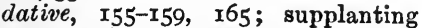
accusative, I7I ; syntax, I79, I82r84-r86; prepositions with, I94; with dative and instrumental, r97. de, 35 .

declension, 52 ; first, or strong, 55 ; remarks on first, $56,57,59,60$ (2) ; second, or weak, $6 \mathrm{I}$; remarks on second, 62 ; of anomalous nouns, 67 ; of adjectives, 72-75; of participles, 78 ; of numerals, $90-92$; of pronouns, 94 ff.; definite, 75 ; indefinite, 73 ; summary of declensions, $7 \mathrm{I}$.

deend, I9I (3).

defective nouns, 68.

deil, 27 (3).

demonstratives, 99, 100.

dentals, 32.

dhâman, $\mathbf{1 4 7}$ (2).

di, 3.5 .

diminutives, 70 .

dine, 35 .

dinne, 35 .

diphthongs, 14.

direct object, 177.

distributive, $a, 92$ (2).

dizze, 35 .

djop, $\mathbf{I}_{4}(2)$.

dju, $14(2)$.

doghs, 35 .

dolge and dolck, 7 .

$-d \hat{m}, \mathrm{r} 47$; gender of nouns ending in, 48 .

dou, 35 .

double superlative, 82 ; accusative, 187.

doz, 35 .

$d r \cdot$ ind, r9r (3).

dual, 98.

Dutch influence on Friesic, I (4), 29 (3).

dwâlicheed, 28 (4).

$d y, 35$.

$d z, 37(2)$.

$e, 4$; euphonically inserted, 5 ; umlaut, 46 ; intensive prefix, 192.

$-e, 14^{8}$; gender of nouns ending in, 48 $(2,3)$; plurals in, $57(5)$; adverbial termination, I49; relic of ancient $-j a, 57(6), 77, \mathbf{1 2 5}$

$e$-, privative particle, $\mathrm{I} 92$.

$\hat{e}$, Io; umlaut of $\hat{\sigma}$, 10 (9).

-êde, -hed, 48, (2 c.)

eeri, 27 (3).

$e i, \mathrm{I}_{5}$; -eg vocalised into, $3^{8}$ (2); condensed into $\hat{\imath}, 3^{8}(3)$.

- $e l$, gender of nouns ending in, 48 (I). -elsa, 147; gender of nouns ending in, $48(\mathrm{r})$.

emphasis, arrangement for sake of, I53.

emphatic superlative, $85^{*}$. 
Emsiger Recht, $t$ in, 32 (I) ; 82 ; plurals, $57 ; a$ distributive in, 92 (2).

ên, declined, go.

-en, gender of nouns ending in, 48

(3); plurals in, 57 ; suffix, I46, 148.

end, used to form emphatic superlative, $85^{*}$.

end rhyme, 204, 205.

-er, -ere, suffix, $\mathrm{x}_{46}, \mathrm{I}_{47}, \mathrm{I} 49$ (3).

-ere, gender of nouns ending in, 48 (I). $-e r,-e r n, x 48$.

-eth, gender of nouns ending in, $4^{8}$ (2).

êth, declined, 55 .

-ethe, -the, $x 47$.

etymology, nouns, 47 ; adjectives, 72 ; numerals, 87 ; pronouns, 94 ; verbs, 104.

$e u, 18$.

expletive (sâ), 200.

$f, 3^{\mathrm{I}}$; rendering Anglo-Saxon combination $h w, 3^{\mathrm{I}}(3)$.

-fald, 148 .

feder, declined, 64.

feminine nouns, 48 (2), and see under the declensions.

fia, declined, 60.

finda, conjugated, II2.

following, syntax with verbs of, 179 . Fôr, dialect of, $t h$ in, 34 .

foreign proper nouns, 69.

forgiving, syntax with verbs of, 179 .

forth-, 145 .

Fosite, 27 (3)t.

Fracture, 44.

Frankish, ei, ${ }_{5}$ (7).

freeing from, syntax with verbs of, 180.

friund, declined, 65 .

ful-, 145 .

future, see verbal paradigms; present used for, 188.

future perfect, II.

$g, 37(2), 3^{8}$; loss of, compensated by $e u, 18$; changed to $i, 3^{8}(5)$.

ge-, intensive prefix, 192.

géan, $27^{*}$.

yemination, 23 (4), 27 (4); diphthongal, 28 (8).

gender, rules for, $47,48,49$, ; peculiarity of $w \hat{\imath} f, 5 \mathrm{I}$; nouns of more than one, 50 .

genitive, 154, 160-163, 167, 169, 173, I85; prepositions with, I96.

German, gender, 47 ; syntax, 150.

gerund, see verbal paradigms, and
Sections 120, I9I; case - ending omitted, I9I (2).

Gesta Fresonum, 213.

giving, syntax with verbs of, 179.

gôd, declined, 73, 75 .

Gothic, vowels, see the various letters ; neuter nouns, $57(3)$; nasal $\hat{a}, \mathrm{I} 2(2)$.

governing, syntax of verbs of, I80.

Greek, neuter plurals, 57 (3); peculiar numeral compounds, 93 t.

gungi, 27 (3).

gutturals, $3^{6}$; replacing spirant, 31

(4) ; replacing $b, 3^{\text {I }}(4)$; arbitrarily inserted in pagus, $3 \mathrm{I}(4)$; in Saterlandish, 3I (4); converted into a palatal, 37 .

$h, 2$ (4), 39; lost from verbal forms, 123.

half, with numerals, $x 74$.

hearkening to, syntax with, 179 .

-hed, -êde, I47; gender of nouns ending in, 48 (2).

Heligoland, dialect of, diphthong iu in, 14 (2); infinitive, $27(3)$; article, 99 (2).

helping, syntax with verbs of, I79, 182.

herne, 25 .

$h i$, declined, 94 .

hiâr, 27 (3).

Hindelopian, 64* ; 70; I9I (3).

$h l, h r, 23$ (I), 39.

$h n, 39$.

hôn, 25 .

hona, declined, $6 \mathbf{r}$.

$h r, 39$.

hund, relic of, 88.

Hunsingoer Recht, 57, 82.

$h w, 2(4), 39$.

hwa, declined, ror.

$i, 6$; pronoun, 94 ; Brechung, 6 (2) ; intensive prefix, 192 ; umlaut, 46 ; as subjunctive termination, 138 .

$-i$, themes in, $5^{8}$; Modern-Friesic in-

finitives, $27(3)$; plural in, 57 (5).

$\hat{\imath}$, II.

ia, $\mathbf{1 4}$.

Icelandic, gender, 47 ; vowels, see under the various letters.

-ick, I 48.

$i e$-, intensive prefix, 192.

-igja, \&c., in weak verbs, 136 .

$i k$, declined, 94.

imitating, syntax with verbs of, 179 .

imperative, 170 , and see paradigms.

impersonals, 184 .

in-, I45. 
indefinite, declension, 73; article, I76 ; numeral, 175; pronouns, 103.

indicative, strong, I12; weak, 128.

indivect object, $\mathbf{1} 56$.

infinitive, see paradigms; ModernFriesic, 27 (3).

inflection, of nouns, strong, $55 \mathrm{ff}$.; weak, $6 \mathrm{r}$; of adjectives, definite, 75 ; indefinite, 73 ; of verbs, strong, x 10; weak, 128; in Modern-Friesic, 54.

influence, syntax with verbs of, 179.

-ing, $\mathrm{r}_{46}$; gender of nouns ending in, 48 ( $\mathrm{r}$ ).

-inge, -unge, $\mathrm{r} 47$.

inseparable prefixes, $14 \mathrm{I}(a)$.

instrumental, 99 (3); prepositions with, and with other cases, 197.

intensive prefix, 192.

interjections, 203.

interrogative, pronouns, ror ; adverbs, $202(2)$.

io, 14.

-isk, -esk, $\mathbf{1 4 8 .}$

it, 27 (3).

$i u, \mathbf{1} 4$.

$j, 2(5), 30$.

$-j a$, themes in, $57(6)$; in verbs, 110 , $125,128$.

jaen, $27^{*}$.

ját, declined, 98.

$-j e$, as subjunctive termination, $13^{8}$.

jemma, personal pronoun, $94^{*}$.

jen, pronoun, 95 (r).

jied (Helig.), $\mathrm{r}_{4}$ (2).

$j u, 95$ (r).

junk (Helig.), I4 (2).

jûr (Helig.) $\mathrm{I}_{4}(2)$.

juued (Schierm.), I4 (2).

judging, syntax with verbs of, 179.

$k, 2(6), 3^{6}, 37$.

kan, 126.

$-k e$, diminutive in, 70 .

Kentish, délan, énio, ro (4); g changed to $i, 3^{8}(5)$.

kerne, 25.

kiasa, conjugated, r12.

$k o e^{\prime} d, 23$ (2).

kôn, 25 .

$l, 23$; ou as compensation for, $2 \mathrm{r}$.

$-l$, gender of nouns ending in, $4^{8}$ $(\mathrm{r}, d)$.

labials, $3 \mathbf{r}$.

$-l \hat{s}, 148$.

Latin, o, 8 (3); neuter plurals, 57
(3) ; syntax, r5o; monachus, 8 (3); pondus, 8 (3); $p, 3$ I (4).

libba, $\mathbf{1 3 7 .}$

lied, 27 (3).

$-l \hat{\imath} k, \mathrm{r}_{4} 8$.

likeness, syntax with verbs of, $\mathbf{r} 79$.

Lindhold, dual, 98.

liode, declined, $5^{8}$.

liquids, $23(\mathrm{x})$.

list, of nouns of more than one gen-

der, 50 ; of strong nouns, 56,59 ;

of weak nouns, 63 ; of nouns with themes in $-r, 64$; themes in $-n d$, 65 ; of indefinite pronouns, I03; of strong verbal classes, 110 ; of verbs to illustrate the classes, II I ; of $p r c e$ terito-proesentia, 126; of prepositions with various cases, 193-197; of principal conjunctions, r99; of interjections, 203; of adjectives irregularly and defectively compared, 85 ; of weak verbs, 129.

listening, syntax with verbs of, 179 .

lith, plural in $-i, 57(5)$.

logical subject, 184 .

long vowels, 9 , $\mathrm{ff}$.

$l v$ and $l f, 2(7)$.

$m, 27(5)$

$-m$, gender of nouns ending in, 48 ( 1 ). $m a$, verb agreeing with, in plural, ro3* ; euphonic $-r$ suffixed to, $103^{*}$. $-m a$, r 47 ; gender of nouus ending in, 48 ( 1 ) ; superlative in, 82.

macki, 27 (3).

makja, followed by double accusative, \&c., 187 .

manner and means, $1_{5} 6$.

masculine, $4^{8}(\mathrm{I})$; nouns, $4^{8}(\mathrm{x})$, and see the declensions.

material, syntax of, 160 .

$m e i, m \hat{\imath}, 126$.

metathesis, 26, 127.

Middle-Friesic, 28 (4); rhymes, 213.

middle sense in certain verbs, $145^{*}$.

mis-, 145.

miss, to, syntax of, $\mathrm{r} 8 \mathrm{o}$.

Modern-Friesic, 7, 14 (2), 23, 25, 27 (3), 28 (5), 3I (4), 34, 35, 37 (2), 38, 54, 57, 64* 70,96 (2), 98 , I9I (3).

mon, declined, 67.

monig, 175 .

moods, 105.

$m o \hat{t}, \mathbf{1 2 6 .}$

multiplicatives, 92 (4).

mutes, 3 I.

$n, 27 \mathrm{ff}$. ; inserted in verbal themes, 
IIO; in Northumbrian AngloSaxon, 27 (2).

naht, declined, 66.

nasals, 27.

$-n d$, stems in, 65; gender of nouns ending in, 48 ( 1 ).

$n \hat{e} d$, declined, 58 .

negation, particles of, 202 ; ne transposed, 26.

nera, conjugated, 128.

-nese, $\mathrm{I}_{47}$.

neuter nouns, 48 (3), and see under the different declensions.

North-Friesic, dual, 98.

Northumbrian Anglo-Saxon, 27 (2).

Norwegian, 25.

nouns, 47 ff. ; syntax, 154 .

numbers, 52.

numerals, 87 ff. ; a distributive numeral, $92(2)$; peculiar use of sum with, 93 ; indefiuite, 175 .

$0,7$.

$\hat{0}, 12$.

object, direct, 177 ; indirect, $\mathrm{I}_{5} 6$.

observing, syntax with verbs of, I8o. obtain, to, syntax of, 180.

-och, $\mathrm{x} 48$.

oe, 20.

of, I 45 .

Olde Freesche Chronike, 213.

Old-High-German, vowels, \&c., see under the various letters.

oggen, $3^{\text {I }}$ (4).

omission of consonants, 40.

on-, 145 .

ond-, 145 .

onder-, 145 .

Old-Saxon, see under the different

letters.

ordinals, 89.

ou, 2 I.

$p, 3$ I.

palatals, conversion of gutturals into, 37.

paradigms, of verbs, strong, II2; weak 128.

parallelism, 2 Io.

participles, see under the paradigms,

also 122, 135; active with passive sense, I9o.

particles, of interrogation, 202 ; of negation, 202 ; meaning lost in compounds, I4I (a.) ; privative, I92.

partitives, govern genitive, 161, 167, 169.

passive voice, II2.

periphrastic conditional conjugation, I26. place, adverbs of, 149 (3).

Platt-Deutsch, 25.

pleasing, syntax with verbs of, I79, I84.

pluperfect, I12, 128 .

popular songs, national, 212.

possessive pronouns, 95 (2).

prcepositus, 3 I (4).

proterito-prosentia, ז26; verbs fol-

lowing analogy of, 127 .

praveśayami, 188.

prefixes, $3^{8}(4)$, 145 .

prepositions, 193-198 ; with accusative, I93; with dative, I94; with dative and acc., r95; with genitive, 196; with instrumental, 197 ; double, I98.

present, indicative and subjunctive, II2, 128; theme, strong verbs, II 2 ; theme, weak verbs, I28; used for future, 188.

preterit, see the verbal paradigms.

privative particle, 192.

pronouns, 94 ff.; omitted with imperative, I70; possessive, 95 (2); syntax, 168; demonstrative, 99, roo; interrogative, IOI ; relative, IO2 ; indefinite, IO3; contracted, 96, 97; reflexives, I72; dual, 98.

pronunciation, of $r, 23(6)$; of palatals, 37 ; of vowels, 1 ; of consonants, 2 ; of $l f$ and $l v, 2(7) ; w l$ and $w r, 2$ (9); of $t h$, see dentals ; of $l$ and $r, 24$; of Modern-Friesic, see Modern-Friesic.

proper names, 37 (6), 69.

prosody, 204, ff.

providing against, syntax, 180 .

purging legally, syntax, 182 .

$q, 22$.

quantity, syntax of nouns expressing, I6o.

$r$, 23 ; dropped, 24 ; pronunciation, 23 (6), 24 ; added to $m a$, Iо3.

$-r, 149$ (3).

redundant letter's, in verbs, 136.

reduplication, IIO.

reflexives, $\mathbf{1} 72$.

relative pronouns, IO2.

repaying, syntax with verbs of, 179 .

repetition of negatives, 202 (3).

requesting, syntax, 180 .

rhotacism, $23(6), 29$; in verbs, 117 .

rhyme, 204, 205.

-rike, 147.

Risum, dual, 98.

rob, syntax of, I82. 
Rückumlaut, I34.

Rüstringer Recht, 19, 207 ; plurals in, 57 ; superlative, 82 .

$s, 2$ (8), 29; for $t h, 33$; a plural ending in, 64 .

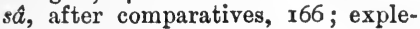
tive, 200.

salvja, conjugated, I28.

Sanskrit, plural of neuter nouns, 57

(3) ; peculiar numeral compounds, 93.

Saterlandish, wîla, II (I) ; $d$ before diphthong, I4 (2); gutturals, 3 I (4).

Schiermonnikoog, dialect of, $d$ before diphthong, If (2).

scoed, 23 (3).

seem to, to, syntax of, 184 .

sei, 27 (3).

sêka, conjugated, I28.

-sel, gender of nouns ending in, 48 (3). sêle, declined, 55 .

serving, syntax with verbs of, 179.

short vowels, 3-8.

siend, I9I (3).

sjaen, $27^{*}$.

skil, 126.

-skip, I47; gender of nouns ending in, 146 .

skip, declined, 55 .

sliap, 27 (3).

songs, popular, 2 I2.

speaking against, syntax with verbs of, I79.

spirants, $28 \mathrm{ff}$.

stéan, $27^{*}$.

sth, 37 .

strong, nouns, 55; adjectives, 73 i verbs, IIO.

subject, place for, 153; logical, 184.

subjunctive, see paradigms; syntax, 189 ; with what conjunctions, I 89 $(4,5), 201$; used for imperative, 189. suffixes, I46; contracted, 84; of comparatives, 79 ; of superlatives, 79 ; denoting personal agents, 146 ; abstract notions, circumstances, and things, 147 .

sum, with numerals, 93 .

-sum, I48.

summary of the declensions, $7 \mathbf{I}$.

sun $u$, declined, 60 .

superlative, $79,82,84$; in ordinals, 89 ; as partitive, 167 .

Sylt, dialect of, dual, 98 .

syncope, $74,77,84,{ }^{1} 32$, I $40 *$.

syntax, general principles, I50-153 ; of accusative, $180-183,186,187$; of adjectives, $151,163-167$; of verbs, I52, I77-I92; of nouns, I54-I62; of pronouns, I68-I72; of numerals, I73-I76; of prepositions, I93-I98; conjunctions, I99202 ; adverbs, 202 ; interjections, 203; of dative, I55-I59, I65, I79, r82-187; with comparative and superlative, 156 ; with genitive, I54, I60-163, I67, I69, I73, I80.

$s z, 37$.

$t, 32$.

$t-$, as relic of hund, 88 .

$-t a$, I48.

take from, syntax, 183 .

taking care of or for, syntax with verbs of, 180 .

-te, gender of nouns ending in, 48 (3). tenses, 106.

th, 33 ; pronunciation, 34 ; for $f, 33$ (3).

tha or than, after comparatives, 166.

thacke, 34 .

thaank, 34 .

thârp, 34 .

-the, 147.

themes, $-a, 5^{8} ;-i, 5^{8} ;-u, 60 ;-a n$, $61 ;-r, 64 ;-v a, 57(7) ;-n d, 65$; ending in a guttural or dental, 66 ; anomalous, 67.

thênk, 27 (3).

Thet Freske Riim, 2 I3.

thi, declined, 99.

thiif, 34 .

thing, 34 .

this, declined, roo.

thitsel, 34 .

thôn, 25 .

time, nouns of, $\mathrm{I}_{54}, \mathrm{I}_{55}$.

thruch-, 145.

thu, declined, 94.

thum, 34 .

thur, 126.

thurf, $\mathbf{2} 6$.

thrê, declined, 9 r.

thwong, 34 .

to, in composition, 143 .

$t \hat{o}-$, I 45 .

tôth, declined, 58 .

Trübung, 7, 8.

$t s, t s z, t z, 37$ (2).

tunge, declined, 6r.

twêne, declined, 90.

$u, 8$; for $v$ and $w, 8(4)$; ancient umlaut, 46 (2).

$-u$, gender of nouns ending in, 48 (I); themes in, 60.

$u, \mathrm{I}_{3}$.

$u i, 17$. 
$-u l$, gender of nouns ending in, 48 (I). umbe-, 145 .

Umlaut, rule, 46 ; in the comparative, 83 ; in verbs, II7 ; Rückumlaut, 134 .

un-, I45.

und-, 145 .

under-, $\mathbf{I} 45$.

up-, $\mathbf{1 4 5}$.

Upstalbom, plurals, 57 .

ur-, 145 .

using, syntax with verbs of, 180 .

ut -, 145 .

$v, 28$; for $u, 28$; replacing nasal, 28

(9) ; drops out, 28 (9).

- $v a$, themes in, $57(7)$.

verbs, I04 ff.; auxiliary, 108, 109; strong, Iro; remarks on, Ir6 ff. ; weak, 128 ; remarks on, 130 ff. ; intransitive form, II5; of several stems, I2I ; strong with weak forms, 122 ; proterito-procentia, I26; verbs following analogy of, 127 ; anomalous (without connecting vowel), 139 ; governing dative, 179; genitive, 180 ; accusative and genitive, I8I, 182; the subjunctive, 189 ; voices, IO4 ; moods, IO5 ; tenses, I06; adverbs with, 202 (6). voices, 104.

vowels, 3 , ff. ; long, 9, ff. $w$, aspirated in Modern-Friesic, 28 (5) ; used for $u, 28$ (2); for $w u$, 28 (2); combined with $l$ and $r, 2$ (9), 23, 28 (3); dropped, 28 (7).

Wangerôg, dialect of, infinitive forms, $27(3)$; th in, 34 . wát, declined, 98 .

weak, conjugation, 128 ; verbs, 129 ; nouns, $6 \mathrm{I}$; adjectives, 75 .

wertha, I09.

wesa, conjugated, 108.

West. Friesic, Brechung, 44; (Modern) - an and $-e n$ in, 57 ; article, 99 (2).

West Lauwers Laws, $t$ in, $3^{2}$; diminutive in, 70; than in, 166.

Westphalian, 25 .

wêt, wît, 126.

wi, 94 .

wield, syntax of, 180 .

$w \hat{\imath} / a, \mathrm{II}$.

-wirth, I49 (3).

with - ir, $\mathbf{1} 45$.

withstanding, syntax with verbs of, I79.

wl and wr, 2 (9), 23, 28 (3). woed, 23 (3).

$x=k s, 22,36$.

$y, \operatorname{II}(4)$.

$z, 29(3)$.

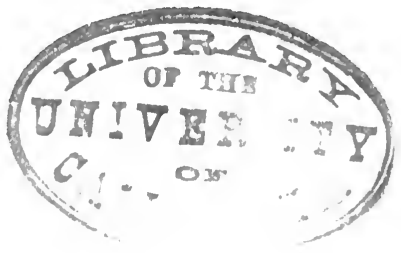




\section{ERRATA.}

The following misprints and errata have been observed:-

Page 22, line 6 from top, for "ver" read "Ger."

23, line 6 from bottom of page, for "Gothô" read "Goth. ô."

29 , line 12 from bottom of page, for " $h w \hat{a}$ " read " $h w a . "$

30 , line 15 from top, for " jondis" read " jond is."

46 , line 6 from top, for "fovne" read "fôvne."

$5 \mathrm{I}$, sec. 87 , for "threttene" read "threttêne, dic."

54 , line 5 from bottom, for "and" read "to."

70 , line 3 from bottom, for "Sonna-bend" read "Sonn-Abend."

78 , sec. 175 , and pp. 117 and 125 , for "monig" read "monich."

85 , line 2 from top, for "ramfara" read " rumfîra."

85, line 23 from top, for " UTA" read " $\mathrm{C}_{\text {TA." }}$

89 , line 5 from top, for "êla" read "ela."

92, last line, for "Lanwers" read "Lauwers."

105, line 7 from top, for "dy" read "hy."

I05, line 9 from top, for " by " read "dy."

I08, line 9 from top, for "hémmel" " read "hemmel."

108 , line 13 from top, for "daitrîk" read "dait rîk."

109, line 8 from bottom, in "dão't " the circumflex should extend over both vowels.

I13, in the Glossary, for "alderto" read "aldêrtô."

I 14, col. 2, after "dijjen," for "pres." read "pers."

The letter " $\mathrm{j}$ " has in some cases, as in "sjuguntich," page 9l, middle of the page, slipped in instead of " $i$."

It is to be hoped that no one will take seriously the amusing etymology of the word "Helder" adduced in the Introduction, p. viii.

It will be found in some instances that the diacritical marks to indicate vowel quantity have dropped off, and in others there has been a mere failure to note them. 



\title{
A CATALOGUE \\ OF \\ DICTIONARIES, GRAMMARS, READING-BOOKS,
}

\author{
AND OTHER IMPORTANT WORKS
}

\author{
OF THE PRINCIPAL \\ LUROPEAN LANGUAGES, \\ PUBLISHED BY \\ TR $\ddot{U} B N E R \quad$ C O.,
}

$57 \& 59$ LUDGATE HILL, LONDON, E.C.

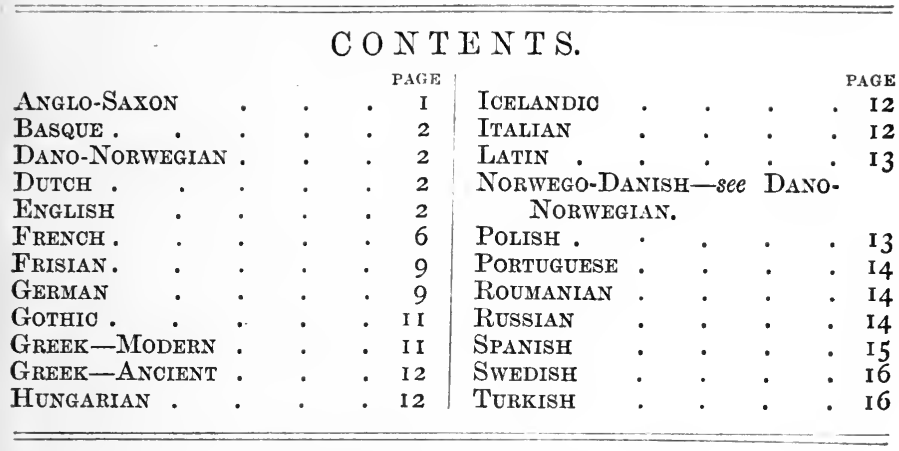

\section{ANGLO-SAXON.}

MARCH.-A COMPARATIVE GRAMMAR OF THE ANGLO-SAXON LAN. GUAGE; in which its forms are illustrated by those of the Sanskrit, Greek, Latin, Gothic, Old Saxon, Old Friesic, Old Norse, and Old High-German. By Francis A. March, LL.D. Demy 8vo, cloth, pp. xi. and 253. 1877. Price Ios.

MARCH.-INTRODUCTION TO ANGLO-SAXON. An Anglo-Saxon Reader. With Philological Notes, a Brief Grammar, and a Vocabulary. By Francis A. March, LL.D. 8vo, cloth, pp. viii. and i66. I870. Price 7s. 6d.

RASK.-GRAMMAR OF THE ANGLO-SAXON TONGUE, from the Danish of Erasmus Rask. By Benjamin Thorpe. Third Edition, corrected and improved, with Plate. Post 8vo, cloth, pp. vi. and I9r. I879. Price 5s. 6d.

WRIGHT.-ANGLO-SAXON AND OLD ENGLISH VOCABULARIES. BY Thomas Wright, M.A., F.S.A., Hon. M.R.S.L. Second Edition, Edited and Collated by Richard Paur Wulcker. Two vols. demy $8 v o$, pp. xx. -408 , and iv. -486 , cloth. 1884. 28s. Illustrating the Condition and Manners of our Forefathers, as well as the History of the forms of Elementary Education, and of the Languages Spoken in this Island from the Tenth Century to the Fifteenth. 


\section{BASQUE.}

VAN EYS. - OUTLINES OF BASQUE GRAMMAR. BY W. J. VAN EYS. Crown 8vo, cloth, pp. xii. and 52. I883. Price 3s. 6d.

\section{DANO-NORWEGIAN.}

*BOJESEN.-A GUIDE TO THE DANISH LANGUAGE. Designed for English Students. By Mrs. Maria BoJesen. I 2mo, cl., pp. 250. IS63. Price 58. FOSS.-NORWEGIAN GRAMMAR, with Exercises in the Norwegian and English Languages, and a List of Irregular Verbs. By Fritejof Foss. Second Edition, I 2mo, limp cloth, pp. 49. I875 Price 2s.

LARSEN,-DANISH-ENGLISH DICTIONARY. By L. LARSEN. CrOwn 8vo, cloth, pp. 646. I880. Price 7s. 6d.

*OTTÉ.-DANO-NORWEGIAN GRAMMAR: A Manual for students of Danish, based on the Ollendorffian System of teaching Languages, and adapted for self-instruction. By E. C. Отт́́. Second Edition. Crown 8vo, cloth, pp. xix. and 337. 1884. Price 78. 6d.

Key to ditto. Crown 8vo, cloth, pp. 84. Price 3s.

*OTTÉ.-SIMPLIFIED GRAMMAR OF THE DANISH LANGUAGE. BY E. C. OTtê. Crown 8vo, cloth, pp. viii. and 66. I\&84. Price 2s. 6d.

ROSING.-ENGLISH-DANISH DICTIONARY. BY S. ROSING. Crown 8vo, cloth, pp. 722. 1883. Price 8s. 6d.

\section{DUTCH.}

*AHN.-CONCISE GRAMMAR OF THE DUTCH LANGUAGE, with Selections from the Best Authors in Prose and Poetry. By Dr. F. AHN. T'ranslated from the Tenth Original German Edition, and remodelled for the use of English Students, by Henri Van Laun. Third Edition, I 2mo, cloth, pp. vii. and 168. I877. Price 3s. 6d.

KRAMERS. - NEW POCKET DICTIONARY OF THE ENGLISH-DUTCH AND Dutch-English Languages. Containing also in the First Part Pronunciation, and a Vocabulary of Proper Names, Geographical and Historical. By J. KraMers. I6mo, cl., pp. xiv. \& 714. 1876. I'rice 4s. PICARD. - A NEW POCKET DICTIONARY OF THE ENGLISH-DUTCH AND Dotch-English Languages. Remodelled and corrected from the Best Authorities. By A. Picard. Fifth Edition, 16mo, cloth, pp. xiv. and I186. 1877. Price IOs.

\section{ENGLISH.}

*.ANDERSON. - PRACTICAL MERCANTILE CORRESPONDENCE. A COllection of Modern Letters of Business, with Notes, Critical and Explanatory, and an Appendix, containing a Dictionary of Commercial Technicalities, pro forma Invoices, Account Sales, Bills of Lading, and Bills of Exchange ; also an Explanation of the German Chain Rule. Twenty-fourth Edition, revised and enlarged. By William Anderson. 12mo, cloth, pp. xxxii. and 279. I882. Price 5s.

BELL. - SOUNDS AND THEIR RELATIONS. A Complete Manual of Universal Alphabets, Illustrated by means of Visible Speech; and Exhibiting the Pronunciation of English, in Various Styles, and of other Languages and Dialects. By A. Melville BeLL, F.E.I.S., \&c. 4to, cloth, pp. viii. and 102. 1881. Price, 7s. 6d.

BELL.-THE FAULTS OF SPEECH; a Self-Corrector and Teachers Manual. By A. Melville Bell, F.E.I.S. 18mo, cloth, pp. vi. and 65. 1880. Price 2s. 6d. 
BELL.-THE PRINCIPLES OF ELOCUTION, with Exercises and Notations for Pronunciation, Intonation, Emphasis, Gesture, and Emotional Expression. By A. Melville Beld, F.E.I.S., \&c. Fourth Revised and Enlarged Edition. I2mo, cloth, pp. 243. I878. Price 7s. 6d.

BELL.-VISIBLE SPEECH. The Science of Universal Alphabetics; or, Self-Intfrpreting Physiological Letters for the IVriting of all Languages in One Alphabet. Illustrated by Tables, Diagrams and Examples. By A. Melville Beld, F.E.I.S., \&c. 4to, half-bound, pp. I 26. I 867 . Price $£ \mathrm{I}, 5 \mathrm{~s}$.

BELL.-ENGLISH VISIBLE SPEECH FOR THE MILLION for Communi. cating the Exact Pronunciation of the Language to Native and Foreign Learners, and for Teaching Children and Illiterate Adults to Read in a few days. By A. Melville Ber.L, F.E.I.S., \&c. 4to, paper, pp. 16. I867. Price 2s.

EARIY ENGLISH TEXT SOCIETY.-List of Publications on application. ENGLISH DIALECT SOCIETY.-List of Publications on application.

FURNIVALL. -EDUCATION IN EARLY ENGLAND. Some Notes used as Forewords to a Collection of Treatises on "Manners and Meals in Olden Times," for the Early English Text Society. By Frederick J. Furnivall, M.A. 8vo, paper, pp. 4 and lxxiv. I867. Price is.

GALLOWAY.-EDUCATION : SCIENTIFIC AND TECHNICAL; or, HOw the Inductive Sciences are Taught, and How they Ought to be Taught. By R. Galloway, F.C.S. 8vo, cl., pp. xvi. \& 462. I88I. Price ros.6d. GOULD.-GOOD ENGLISH ; or, Popular Errors in Language. By Edward S. Gould. New Edition. Crown 8vo, cloth, pp. ix. and 214. I88o. Price 6s.

HALL.-ON ENGLISH ADJECTIVES IN -ABLE, with Special Reference to Reliable. By Frtzedwakd Hall, C.E., M.A., Hon. D.C.L., Oxon. Crown 8vo, cloth, pp. viii. and 238. 1877. Price 7s. 6d.

HALL.-MODERN ENGLISH. By FITZEDWARD HALL, M.A., Hon. D.C.L., Oxon. Crown 8vo, cloth, pp. xvi. and 394. I873. Price Ios. 6d.

HARLEY.-THE SIMPLIFICATION OF ENGLISH SPELLING, specially adapted to the Rising Generation. An Easy Way of Saving Time in Writing, Printing, and Reading. By Dr. George Harley, F.R.S., F C.S. 8vo, cloth, pp. I28. I877. Price 2s. 6d.

HYMANS.-PUPIL versus TEACHER. Letters from a Teacher to a Teacher. I8mo, cloth, pp. 92. I875. Price 2s.

INMAN.-HISTORY OF THE ENGLISH ALPHABET. A Paper read before the Liverpool Literary and Philosophical Society. By T. InMaN, M.D. 8vo, paper, pp. 36. I872. Price Is.

JENKINS.-VEST-POCKET LEXICON. An English Dictionary of all except Familiar Words, including the principal Scientific and Technical Terms, and Foreign Moneys, Weights and Measures; omitting what everybody knows, and containing what everybody wants to know and cannot readily find. By J JBEZ Jenkins. 6́4mo, cloth, pp. 563. I879. Price Is. 6d.

MANNING.-AN INQUIRY INTO THE CHARACTER AND ORIGIN OF THE Possessive Augment in English and in Cognate Dialects. By the late James Manning, Q.A.S., Recorder of Oxford. 8vo, paper, pp. iv. and 90. I864. Price 2s.

NEWMAN.-THE ILIAD OF HOMER, faithfully Translated into Un. rhymed English Metre. By F. W. NewMaN. Royal 8vo, cloth, pp. xvi. and 384 . I871. Price ros. 6 d. 
PARRY.-A SHORT CHAPTER ON LETTER-CHANGE, with Examples. Being chiefly an attempt to reduce in a simple manner the principal classical and cognate words to their primitive meanings. By J. Parry, B.A., formerly Scholar of Corpus Christi College, Cambridge. Fcap. 8vo, pp. I6, wrapper. I884. Price Is.

PHILOLOGICAL SOCIETY PUBLICATIONS. - List on application.

PLINY.-THE LETTERS OF PLINY THE YOUNGER. Translated by J. D. Lewis, M.A., Trinity College, Cambridge. Post 8vo, cloth, pp. vii. and 39o. I879. Price 5s.

PLUMPTRE.-KING'S COLLEGE LECTURES ON ELOCUTION; or, The Physiology and Culture of Voice and Speech, and the Expression of the Emotions by Language, Countenance and Gesture. To which is added a Special Lecture on the Causes and Cure of the Impediments of Speech. Being the Substance of the Introductory Course of Lectures annually delivered by Charles John Plumptre, Lecturer on Public Reading and Speaking at King's College, London, in the Evening Classes Department. Dedicated by permission to H. R. H. the Prince of Wales. Fourth and greatiy enlarged Illustrated Edition. 8vo, cloth, pp. xvi. and 494. I883. Price I5s.

PLUMPTRE. - THE RIGHT MODE OF RESPIRATION, in Regard to Speech, Song, and Health. By Charles John Plumptre, Author of "King's College Lectures on Elocution," of which this forms Lecture VI. Demy 8vo, pp. iv.-I6, wrapper, is.

RUNDALL. - A SHORT AND EASY WAY TO WRITE ENGLISH AS SPOKEN. By J. B. Rundall, Certificated Member of the London Shorthand Writers' Association. Price 6d.

SIEVERS. - AN OLD ENGLISH GRAMMAR. BY EDUARD SIEVERS, Ph.D., Professor of Germanic Philology in the University of Tübingen. Translated and Edited by AlbenT S. Cook, Ph.D. (Jena), Professor of the English Language and Literature in the University of California. Crown 8vo, cloth, pp. xvi. and 235. Price 6s. $6 \mathrm{~d}$.

SMITH. - THE SCHOOL OF ART DRAWING BOOK. By WALTER SMITH, late Head-Master of Leeds School of Art, State Director of Art Education, Massachusetts. Perspective Drawing in Two Parts. Oblong 8vo, paper. 1874. Price 2s. 6d. each.

SPRUNER.- HISTORICO-GEOGRAPHICAL HAND-ATLAS. By Dr. KARL Von Spruner. Third Edition. Twenty-seven Coloured Maps Oblong cloth. I872. Price $15 \mathrm{~s}$.

TECHNOLOGICAL DICTIONARY OF THE TERMS EMPLOYED IN THE Arts AND ScIences; Architecture, Civil, Military, and Naval ; Civil Engineering; Mechanics; Machine Making; Shipbuilding and Navigation; Metallurgy ; Artillery ; Mathematics; Physics ; Chemistry ; Mineralogy, \&c. With a Preface by Dr. K. Karmarsch. Second Edition. 3 vols.

Vol. I. German-English-French. 8vo, cloth, pp. 646. Price I2s.

Vol. II. English-German-French. 8vo, cloth, pp. 666. Price I2s.

Vol. III. French-German-English. 8vo, cloth, pp. 618, Price I28. TECHNOLOGICAL DICTIONARY IN THE ENGLISH AND GERMAN LANguages. Edited by Gustav Eger, Professor of the Polytechnic School of Darmstadt, and Sworn Translator of the Grand Ducal Ministerial Departments. Technically revised and enlarged by OTTO BRANDEs, Chemist. 2 vols., royal Svo, cloth, pp. viii, and 712 , and pp. viii. and 970. I884. £ I, 78. 
TECHNOLOGICAL DICTIONARY.-A POCKET DICTIONARY OF TECHNIcal Terms used in Arts and Manufactures. English-GermanFrench, Deutsch-Englisch-Französisch, Français-Allemand-Anglais. Abridged from the above. With the addition of Commercial Terms. 3 vols. sq. I2mo, cloth. Price $12 \mathrm{~s}$.

TURNER.-THE ENGLISH LANGUAGE. A Concise History of the English Language, with a Glossary showing the Derivation and Pronunciation of the English Words. By Roger Turner. In German and English on opposite Pages. I8mo, pp. viii.-8o, sewed. I884. Price Is. $6 \mathrm{~d}$.

UNGER.-SHORT CUT TO READING. The Child's First Book of Lessons. Part I. By IV. H. UNGer. Seventh Edition. Crown 8vo, cloth, pp. 32. 187S. Price 5d. In folio sheets, pp. 44. Sets A to D, rod. each; set E, 8d. Complete, 4s. Sequel to Part I. and Part II. Sixth Edition. Crown 8vo, cloth, pp. 64. I877. Price 6d. Parts I. and II. in One Volume. Third Edition. Demy 8vo, cloth, pp. 76. I873. Price Is. 6d. UNGER.-CONTINUOUS SUPPLEMENTARY WRITING MODELS, designed to impart not only a Good Business Hand, but Correctness in Transcribing. By IV. H. UNGer. New Edition. Oblong 8vo, stiff covers, pp. 44. Price 61.

UNGER.-THE STUDENT'S BLUE BOOK. Being Selections from Official Correspondence, Reports, \&c. ; for Exercises in Reading and Copying Manuscripts, Writing, Orthography, Punctuation, Dictation, Précis, Indexing, and Digesting, and Tabulating Accounts and Returns, Compiled by W. H. UNGER. Folio, paper, pp. Ioo. 1875. Price 2s.

UNGER. - TWO HUNDRED TESTS IN ENGLISH ORTHOGRAPHY, or Word Dictations. Compiled by IV. H. Unger. Fcap. 8vo, cloth, pp. vi. and 200. 1877. Price Is. 6d.; interleaved, 2s. 6d.

UNGER.-THE SCRIPT PRIMER. By which one of the Remaining Difficulties of Children is entirely removed in the First Stages, and, as a consequence, a considerable saving of time will be effected. In Two Parts. By W. H. Unger. Part I. I 2 mo, cloth, pp. xv. and 44. 1879. Price 5d. Part II. I2mo, cloth, pp. 59. I879. Price 5d.

UNGER.-PRELIMINARY WORD DICTATIONS ON THE RULES FOR Spelling. By W. H. Unger. I8mo, cloth, pp. 44. Price 4d.; interleaved, $6 \mathrm{~d}$.

WEDGWOOD.-THE PRINCIPLES OF GEOMETRICAL DEMONSTRATION, reduced from the Original Conception of Space and Form. By $\mathrm{H}$. WedGWood, M.A. I 2 mo, cloth, pp. 48 . I844. Price 2 s.

WEDGWOOD.-ON THE DEVELOPMENT OF THE UNDERSTANDING. BY H. Wedgwood, M.A. I 2 mo, cloth, pp. I33. I848. Price 3s.

WEDGWOOD.-THE GEOMETRY OF THE THREE FIRST BOOKS OF Euclid. By Direct Proof from Definitions alone. By H. WVedawood, M.A. I 2 mo, cloth, pp. IO4. I856. Price 3s.

WEDGWOOD.-ON THE ORIGIN OF LANGUAGE. By H. WEDGWOOD, M.A. I2mo, cloth, pp. I65. I866. Price 3s. 6d.

WEDGWOOD.-A DICTIONARY OF ENGLISH ETYMOLOGY. By $\mathbf{H}$. WEDGWOOD, M.A. Third Edition, revised and enlarged. With Introduction on the Origin of Language. 8vo, cloth, pp. lxxii. and 746. I878. Price $\& \mathbf{r}$, Is.

WEDGWOOD.-CONTESTED ETYMOLOGIES IN THE DICTIONARY OF the Rev. IV. IV. Skeat. By H. Wedgwood, Crown Svo, cloth, pp. viii.-I94. I882. Price 5s. 
WHITE.-WORDS AND THEIR USES, PAST AND PRESENT. A Study of the English Language. By Richard Grant White. Third Edition, Revised and Corrected. Crown 8vo, cloth, pp. vii. and 467. I880. Price Ios.

WHITE.-EVERY-DAY ENGLISH. A sequel to Words and their Uses. By Richard Grant White. Crown 8vo, cloth, pp. xxxi. and 512. 1880. Price IOS.

WIEBE. - THE PARADISE OF CHILDHOOD. A Manual for Self-Instruction in Friederich Froebel's Educational Principles, and a Practical Guide to Kinder-Gartners. By EDWARD Wiebé. With Seventy-four Plates of Illustrations. 4to, paper, pp. iv. -83 . I869. Price $7 \mathrm{s.} 6 \mathrm{~d}$.

WIEBE.-HANDBOOK FOR THE KINDERGARTEN. Containing the valuable Plates of the Paradise of Childhood. Prefaced by New and Original Notes and Suggestions. Edited by Mrs. A. R. Ald RICH. With Seventy-four Plates. 4to, paper, pp. I6. Price 5s.

WITHERS. - THE ENGLISH LANGUAGE SPELLED AS PRONOUNCED, with Enlarged Alphabet of Forty Letters, a Letter for each Distinct Element in the Language. By G. Withers. 8vo, paper, pp. 77. 1874. Price Is.

\section{FRENCH.}

*AHN.-NEW, PRACTICAL, AND EASY METHOD OF LEARNING THE French Language. By Dr. F. Ahn. First Course. I2mo, eloth, pp. I 14. Price 18. 6d. Second Course. I2mo, cloth, pp. I7o. Price Is. 6d. The Two Courses in I vol. 12mo, cloth. 1879. Price 3s.

*AHN.-NEW, PRACTICAL, AND EASY METHOD OF LEARNING TEE French Language. Third Course, containing a French Reader, with Notes and Vocabulary. By H. W. EHrLich. I2mo, cloth, pp. viii. and 125. I877. Price Is. 6d.

*AHN.-MANUAL OF FRENCH CONVERSATION, for the Use of Schools and Travellers. By Dr. F. AHn. I2mo, cloth, pp. $200.187 \mathrm{~S}$. Price 2s. 6d.

*ARAg0.-LES ARISTOCRATIES. A Comedy in Verse. By ËtIENNE Arago. Edited, with English Notes and Notice on Etienne Arago, by the Rev. P. H. E. Brette, B.D., Head-Master of the French School, Christ's Hospital, Examiner in the University of London. I2mo, cloth, pp. xiii. and 235. I869. Price 4s.

ASPLET. - THE COMPLETE FRENCH COURSE. Part II. Containing all the Rules of French Syntax, Irregular Verbs, Adjectives, and Verbs, together with Extracts from the Best Authors. By Georges C. Asplet, French Master, Frome. I2mo, cloth, pp. xviii. and 276. I88o. Price 2s. 6d.

*AUGIER.-DIANE. A Drama in Verse. By EMILE AUGIER. Edited, with English Notes and Notice on Augier, by ThEODORE KARCHER, LL. B., of the Royal Military Academy and the University of London. I $2 \mathrm{mo}$, cloth, pp. xiii. and I45. I867. Price 2s. 6d.

BARANOWSKI.-VADE-MECUM DE LA LANGUE FRANCAISE. Rédigé d'après les Dictionnaires classiques avec les Fxemples de Bonnes Locutions que donne l'Académie Française, on qu'on trouve dans les ouvrages des plus célèbres auteurs. Par J. J. BARANowski, avec l'approbation de M. E. LitTRé, Sénateur, \&c. 32mo, cloth, pp. x.-223. I879. Price 2s. 6d. ; morocco, 3s. 6d.; morocco tuck, 4s.

*BARRIERE AND CAPENDU. - LES FAUX BONSHOMMES. A Comedy. BY Théodore Barrière and Ernest Capendu. Edited, with English Notes and Notice on Barrière, by Professor CH. CASSAL, LL.D., of University College, London. 12mo, cloth, pp. xvi. and 304. 1868. Price 4s. 
BELLOWS.-TOUS LES VERBES. Conjugations of all the Verbs in the French and English Languages. By JoHN BeLlows. Revised by Professor Beljame, B.A., I.L.B., and George B. Strickland, late Assistant French Master, Royal Naval School, London. Also a New Table of Equivalent Values of French and English Money, Weights, and Measures. 32mo, sewed, pp. 32. I867. Price Is.

BELLOWS.-DICTIONARY FOR THE POCKET. French and EnglishEnglish and French. Both divisions on same page. By ЈоHN Bellows. Masculine and Feminine Words shown by distinguishing Types, Coujugations of all the Verbs, Liaison marked in French Part, and Hints to Aid Pronunciation, together with Tables and Maps. Revised by Alexandre Beljame, M.A. Second Edition. 32mo, roan tuck, pp. 6o8. I88o. Price Ios. 6d.; morocco tuck, 12s. 6d. The New Edition, which is but six ounces in weight, has been remodelled, and contains many thousands of additional Words and Renderings. Miniature Maps of France, the British Isles, Paris, and London, are added to the Geographical Section.

*BRETTE.-FRENCH EXAMINATION PAPERS set at the University London from 1839 to I87 I. Arranged and edited by the Rev. P. H. Ernest Brette, B.D. Crown, 8vo, cloth, pp. viii. and 278 . Price 3s. 6d. ; interleaved, 4s. $6 \mathrm{~d}$.

CASSAL.-GLOSSARY OF IDIOMS, GALLICISMS, and other Difficulties contained in the Senior Course of the Modern French Reader. With Short Notices of the most important French Writers and Historical or Literary Characters, and Hints as to the Works to be Read or Studied. By Charles Cassal, LL.D. I2mo, cloth, pp. viii. and ro4. 1880. Price 2s. 6d.

*EHRLICH.-FRENCH READER. With Notes and Vocabulary. By H. W. Ehrlich. I2mo, limp cloth, pp. viii. and 125. I877. Price Is. 6d.

FRUSTON.-ECHO FRANCAIS. A Practical Guide to French Conversation. By F. De la Fruston. With a Complete Vocabulary. Second Edition. Crown 8vo, cloth, pp. 120 and 7 r. I878. Price 3 s.

GREENE. -NEW METHOD OF LEARNING TO READ, WRITE, AND Speak the French Language; or, First Lessons in French (Introductory to Ollendorff's Larger Grammar). By G. W. Greene, Instructor in Modern Languages in Brown University. Third Edition, enlarged and rewritten. Fcap. 8vo, cloth, pp. $248 . \quad$ I872. Price 3s. 6d.

* KARCHER. - QUESTIONNAIRE FRANCAIS. Questions on French Grammar, Idiomatic Difficulties, and Military Expressions. By Theodore Karcher, LL.B. Fourth Edition, greatly enlarged. Crown 8vo, cloth, pp. viii. and 215 . I879. Price 4s. 6d. ; interleaved with writing paper, 5s. $6 \mathrm{~d}$.

*LE-BRUN.-MATERIALS FOR TRANSLATING FROM ENGLISH INTO French. Being a Short Essay on Translation, followed by a Graduated Selection in Prose and Verse. By L. LE-Brun. Sixth Edition. Revised and corrected by Hent VAN LAUn. Crown 8vo, cloth, pp. xii. and 204. 1882. Price 4s. 6d.

* LITTLE FRENCH READER (The). Extracted from "The Modern French Reader." Edited by Professor C. CAssal, LL.B., and Professor T. Karcher, LL.B. With a New System of Conjugating the French Verbs, by Professor Cassal. Fourth Edition. Crown 8vo, cloth, pp. II2. 1884. Price 2s. 
MANESCA.-THE SERIAL AND ORAL METHOD OF TEACHING LANGOAGES. Adapted to the French. By L. Manesca. New Edition, carefully revised. Crown 8vo, cloth, pp. xxviii. and 535. Price 7s. 6d.

*MARMONTEL.-BÉLISAIRE. Par J. F. MARMONTEL. With Introduction by the Rev. P. H. E. Brette and Professors Cassal and Karcher. Nouvelle Edition, I2mo, cloth, pp. xii. and I23. 1867. Price 2s. 6d.

* MODERN FRENCH READER (The). PROSE. Junior Course. Edited by C. Cassal, LL.D., and Theodore Karcher, LL.B. Seventh Edition. Crown 8vo, cloth, pp. xiv. and 224. I881. Price 2s. $6 \mathrm{~d}$.

* MODERN FRENCH READER (The). PROSE. Senior Course. Edited by C. Cassal, LL.D., and Theodore Karcher, LL.B. Third Edition. Crown 8vo, cl., pp. xi. \& 4I8. r88o. Price 4s. With Glossary. Price 6s.

NOIRIT.-A FRENCH COURSE IN TEN LESSONS. By JULES NOIRIT, B.A. Lessons T.-IV. Crown 8vo, limp cloth, pp. xiv. and So. 1870. Price Is. 6d.

NOIRIT.-FRENCH GRAMIMATICAL QUESTIONS for the Use of Gentlemen Preparing for the Army, Civil Service, Oxford Examinations, \&c., \&c. By Jules NoIrit. Crown 8vo, cloth, pp. 62. I87o. Price Is. ; interleaved, rs. 6d.

NOTLEY.-COMPARATIVE GRAMMAR OF THE FRENCH, ITALIAN, Spanish, and Portuguese Languages. With a Copious Vocabulary. By Edwin A. Notley. Oblong I2mo, cloth, pp. xv. and 396. I86S. Price 7s. 6d.

NUGENT'S IMPROVED FRENCH AND ENGLISH AND ENGLISH AND French Pocket Dictionary. Par SMith. 24mo, cloth, pp. xxxii. and 320 , and 488 . 1875. Price 3 s.

PICK. - PRACTICAL IMETHOD OF ACQUIRING THE FRENCH LAN. GUAGE. By Dr. E. PICK. Second Edition. I8mo, cloth, pp. xi. and 124. 1876. Price Is. $6 \mathrm{~d}$.

*PONSARD.-CHARLOTTE CORDAY. A Tragedy. By F. PONSARD. Edited, with English Notes and Notice on Ponsard, by Professor C. Cassal, LL.D. 'Third Edition. I2mo, cloth, pp. xi. and 133. 187 I. Price 2s. 6d.

* PONSARD. - L'HONNEUR ET I ARGENT. A Comedy. By F. PONSARD. Edited, with English Notes and Memoir of Ponsard, by Professor C. Cassal, IL.D. Second Edition. I2mo, cloth, pp. xvi. and I7I. 1869. Price 3s. 6d.

ROCHE.-FRENCH GRAMMAR for the Use of English Students, adopted for the Public Schools by the Imperial Council of Public Instruction. By A. Roche. Crown 8vo, cloth, pp. xii. and 176. 1869. Price 3s.

ROCHE.-PROSE AND POETRY. Select Pieces from the Best English Authors, for Reading, Composition, and Translation. By A. Roche. Second Edition. Fcap. 8 vo, cl., pp. viii. and 226. 1872. Price 2s. $6 \mathrm{~d}$.

RUNDALL.-METHODE RAPIDE ET FACILE D'ECRIRE LE FRANCAIS comme on le Parle. Par J. B. Rundall. Price 6d.

SAND.-MOLIERE. A Drama in Prose. By GEORGE SAND. Edited, with English Notes and Notice of George Sand, by 'Th. KAroher, LL.B. 12wo, cloth pp. x.x. and 170. 1868. Price 3 s. $6 \mathrm{~d}$. 
* IHÊEATRE FRANCAIS MODERNE. - A Selection of Modern French Plays.

Edited by the Rev. P. H. E. Brette, B.D.; C. Cassal, LL.D.; and Th. Karcher, LL.B.

First Series, in I vol. crown 8vo, cloth. Price 6s. Containing-

Charlotte Corday. A Tragedy. By F. Ponsard. Edited, with English Notes and Notice on Ponsard, by Professor C. Cassal, LL.D.

Diane. A Drama in Verse. By Emile Augier. Edited, with English Notes and Notice on Augier, by Th. Karcher, LL.B.

Le Voyalie A Dieppe. A Comedy in Prose. By Wafflard and Fulgence. Edited, with English Notes, by the Rev. P. H. E. Brette, B.D.

Second Series, crown 8vo, cloth. Price 6s. Containing-

Molitere. A Drama in Prose. By George SAnd. Edited, with English Notes and Notice of George Sand, by TH. KARCHER, LL.B.

Les Aristocratins. A Comedy in Verse. By Etienne Arago. Edited, with English Notes and Notice of Étienne Arago, by the Rev. P. H. E. Brette, B.D.

Third Series, crown 8vo, cloth. Price 6s. Containing-

Les Faux Bonshomires. A Comedy. By Théodore Barkiłre and Ernest Capendu. Edited, with English Notes and Notice on Barrière, by Professor C. CassaL, LL.D.

L'Honneur et l'Argent. A Comedy. By F. Ponsard. Edited, with English Notes and Menoir of Ponsard, by Professor C. Cassal, LL.D.

*VAN IAUN.-GRAMMAR OF THE FRENCH IANGUAGE. In Three Parts. Parts I. and II. Accidence and Syntax. By H. VAN LAdN. Nineteenth Edition. Crown 8vo, cloth, pp. I5I and I20. I880. Price 4s. Part III. Exercises. Eighteenth Edition. Crown 8vo, cloth, pp. xii. and 285. I88o. Price 3s. 6d.

*WAFFLARD AND FULGENCE.-LE VOYAGE A DIEPPE. A Comedy in Prose. By MM. Wafflard and Fulgence. Edited, with English Notes, by the Rev. P. H. E. Brette, B.D. Second Edition, revised, with an Index to the Notes. I 2mo, cloth, pp. I07. I870. Price 2s. 6d.

WELLER.-AN IMPROVED DICTIONARY. English and French, and French and English, including Technical, Scientific, Legal, Commercial, Naval, and Military Terms, Vocabularies of Engineering, \&c., Railway Terms, Steam Navigation, Geographical Names, Ancient Mythology, Classical Antiquity, and Christian Names in present use. By E. Weller. Third Edition. Royal 8vo, cloth, pp. $3^{84}$ and 340. I864. Price 7s. 6d.

WENDLING.-LE VERBE. A Complete Treatise on French Conjugation. By Emile Wendling, B.A. Second Thousand. 8vo, cloth, pp. 7 I. 1875. Price Is. 6d.

$$
F R|S| A N \text {. }
$$

CUMMINS.-GRAMMAR OF THE OLD FRIESIC LANGUAGE. BY A. H. Cummiss, A.M. Crown 8vo, pp. x. and 76, cloth. 1881. Price 3s.6d.

\section{GERMAN.}

*AHN.-PRACTICAL GRAMMLR OF THE GERMAN LANGUAGE, with a Grammatical Index and Glossary of all the German Wurds. By Dr. F. Aнs. A New Edition, containing numerous Additions, Alterations, and Improvements. By Dawson W. Turner, D.C. L., and Prof. F. L. Weinmans. Crown 8vo, cloth, pp.cxii. and 430. 1878. Price 3s.6d. 
*AHN.-NEW, PRACTICAL, AND EASY METHOD OF LEARNING THE German Language. By Dr. F. Ahn. First and Second Course, in $r$ volume, I2mo, cloth, pp. 86 and I20. I 880 . Price 3 s.

KEY to Ditto. I2mo, sewed, pp. 40. Price 8d.

*AHN.-MANUAL OF GERMAN CONVERSATION, or Vade Mecum for Eng. uish 'Travellers. By Dr. F. Ans. Second Edition. 12mo, cloth, pp. x. and 137. I875. Price Is. 6d.

*APEL.-PROSE SPECIMENS FOR TRANSLATION INTO GERMAN, with copious Vocabularies. By H. A PEL. I2mo, cloth, pp. viii. and 246, I862. Price 4s. 6d.

*BENEDIX.DER VETTER. Comedy in Three Acts. By Roderich Benedix. With Grammatical and Explanatory Notes by F. WeInmans, German Master at the Royal Institution School, Liverpool, and G. Zimmermans, Teacher of Modern Languages. I2mo, cloth, pp. 126. I863. Price 2s. 6 d.

BOLIA.-THE GERMAN CALIGRAPHIST. Copies for German Handwriting. By C. Bolıa. Obl. fcap. 4to, sewed, pp. 6. Price Is.

DUSAR.-GRAMMAR OF THE GERMAN LANGUAGE ; with Exercises. By P. Friedrich Dusar, First German Master in the Military Department of Cheltenham College. Second Edition. Crown 8vo, cloth, pp. viii. and 207. I879. Price 4s. 6d.

DUSAR. - GRAMMATICAL COURSE OF THE GERMAN LANGUAGE. By P. Friedrich Dusar. Second Edition. Crown 8vo, cloth, pp. x. and 134. 1877. Price 3s. 6d.

FRIEDRICH.-PROGRESSIVE GERMAN READER. With Copious Notes to the First Part. By P. Friedrich. Second Edition. Crown 8vo, cloth, pp. vii. and I90. I876. Price 4 s. 6 d.

*FRCEMBLING.-GRADUATED GERMAN READER. Consisting of a Selection from the most Popular Writers, arranged progressively; with a complete Vocabulary for the First Part. By Friedrich OTto Frembling, Ph.D. Eighth Edition. I 2mo, cloth, pp. viii. and 306. 1879. Price 3s. 6d.

*FREMBLING.-GRADUATED EXERCISES FOR TRANSLATION INTO German. Consisting of Extracts from the best English Authors, arranged progressively; with an Appendix, containing Idiomatic Notes. By Friedrich Oтto Frombling, Ph.D., Principal German Master at the City of London School. Crown 8vo, cloth, pp. xiv. and 322. With Notes, pp. 66. 1867. Price 4s. 6d. Without Notes, 4s.

LANGE.-GERMAN PROSE WRITING. Comprising English Passages for Translation into German. Selected from Examination Papers of the University of London, the College of Preceptors, London, and the Royal Military Academy, Woolwich, arranged progressively, with Notes and Theoretical as well as Practical Treatises on Themes for the Writing of Essays. By F. K. W. LANGE, Ph.D., Assistant German Master, Royal Academy, Woolwich ; Examiner, Royal College of Preceptors, London. Crown 8vo, pp. viii. and 176, cloth. I881. Price 48.

LANGE, - GERMANIA. A German Reading-Book, arranged Progressively. By Franz K. W. Lange, Ph.D. Part I.-Anthology of German Prose and Poetry, with Vocabulary and Biographical Notes. 8vo, cloth, pp. xvi. and 216. I881. Price 3s. 6d. Part II.-Essays on German History and Institutions. With Notes. 8vo, cloth, pp. 124. Parts I. and II. together. IS8I. Price 5s. 6d. 
LANGE.-GERMAN GRAMMAR PRACTICE. BY F. K. W. LANGE, Ph.D.

\&c. Crown Svo, pp. viii. and 64, cloth. 1882. Price Is. 6d.

LANGE.-COLLOQUIAL GERMAN GRAMMAR. With Special Reference to the Anglo-Saxon Element in the English Language. By F. K. W. LANGE, Ph.D., \&c. Crown 8vo, pp. xxxii. and 380, cloth. I882. Price 4s. 6d.

PICK.-PRACTICAL METHOD OF ACQUIRING THE GERMAN LANGUAGE. By Dr. E. Prck. Second Edition. I 8 mo, cloth, pp. xi. and 80. 1876. Price is. 6d.

REHRIG.-THE SHORTEST ROAD TO GERMAN. Designed for the Use of both Teachers and Students. By F. L. O. Rarig. Crown 8vo, cloth, pp. vii. and 226. I874. Price 7s. 6 d.

RUNDALL.-KURZE UND LEICHTE WEISE DEUTSCH ZU SCHREIBEN wie man es Spricht. Von J. B. Rundall. Price 6d.

SOLLING.-SELECT PASSAGES FROM THE WORKS OF SHAKESPEARE. Translated and Collected. German and English. By G. Solling. I $2 \mathrm{mo}$, cloth, pp. I 55. I866. Price 3s. $6 \mathrm{~d}$.

SOLLING.-DIUTISKA: An Historical and Critical Survey of the Litera. ture of Germany, from the Earliest Period to the Deatl of Goethe. By Gustav Solling. 8vo, cloth, pp. xviii. and 367. I863. Price Ios. 6d.

WOLFRAM.-DEUTSCHES ECHO. The German Echo. A Faithful Mirror of German Conversation. By Ludwig Wolfram. With a Vocabulary, by Henry P. Skelton. Sixth Revised Edition. Crown 8vo, cloth, pp. 128 and 69. 1879. Price 3 s.

\section{GOTHIC.}

SKEAT.-MESO-GOTHIC GLOSSARY, with an Introduction, an Outline of Mœso-Gothic Grammar, and a List of Anglo-Saxon and Old and Modern English Words etymologically connected with Mœso-Gothic. By the Rev. W. W. Sknat. 8vo, cloth. 1868. Price 9s.

\section{GREEK-MODERN.}

CONTOPOULOS. - A LEXICON OF MODERN GREEK-ENGLISH AND English Modern Greek. By N. Contopoulos. Part I. Modern Greek-English. Part II. English Modern Greek. In 2 vols. 8vo, cloth, pp. 460 and 582. I877. Price $27 \mathrm{~s}$.

CONTOPOULOS.-HANDBOOK OF ENGLISH AND GREEK DIALOGUES AND Correspondence, with a Short Guide to the Antiquities of Athens. By N. Contopoulos. Crown 8vo, cloth, pp. 238. Price 2s. 6d.

*GELdart.-A GUIDE To ModerN GREEK. By E. M. GELDART, M.A. Post 8vo, cloth, pp. xii. and 274. 1883. Price 7s. 6d.-KEY, cloth, pp. 28, price 2s. $6 \mathrm{~d}$.

*GELdART.-SIMPLIFIED GRAMIMAR OF MODERN GREEK. By E. M. Geldart, M.A. Crown 8vo, cloth, pp. 68. I883. Price 2s. 6d.

LASCARIDES. - A COMPREHENSIVE PHRASEOLOGICAL ENGLISH. Ancient and Modern Greer Lexicon. Founded upon a Manuscript of G. P. Lascarides, Esq., and compiled by L. Myriantheus, Ph.D. Two vols., cloth, fcap. 8vo, pp. xii. and 1338. 1883. Price Er, ros. 
SOPHOCLES.-ROMAIC OR MODERN GREEK GRAMIIAR. By E. A. SO. PHOCLES. I 2 mo, cl., leather back, pp.xxviii. and I96. I879. Price IOs. 6d.

TIMAYENIS. - THE MODERN GREEK. Its Pronunciation and Relations to Ancient Greek. With an Appendix on the Rules of Accentuation, \&c. By T. T. Timayenis. Crown 8vo, cl., pp. xii. and 216. 1877. Price 7s.6d.

\section{GREEK-ANCIENT.}

KENDRICK. - GREEK OLLENDORFF. Being a Progressive Exhibition of the Principles of the Greek Grammar. Designed for Beginners in Greek, and as a Book of Exercises for Academies and Colleges. By A. C. Kendrick. Crown 8vo, cloth, pp. 37 I. I 876 . Price 9s.

KUHNER. -AN ELEMENTARY GRAMMAR OF THE GREEK LANGUAGE. Containing a Series of Greek and English Exercises for Translation, with the Requisite Vocabularies, and an Appendix on the Homeric Verse and Dialect. By Dr. R. KüHNer. Translated by S. H. TAYLOR, LL.D. I2mo, cloth, pp. xii. and 385 . Price $7 \mathrm{~s} .6 \mathrm{~d}$. LASCARIDES. See above.

\section{HUNGARIAN.}

*SINGER. - A SIMPLIFIED GRAMMAR OF THE HUNGARIAN LANGUAGE. By Ignatius Singer, of Buda-Pesth. Crown 8vo, pp. vi. and 88, cloth. I882. Price 4s. 6d.

\section{ICELANDIC.}

CLEASBY.-ICELANDIC-ENGLISH DICTIONARY. Based on the MS. Collections of the late RICHARD Cleasby. Enlarged and Completed by G. VIGFUSSON. With an Introduction, and a Life of Richard Cleasby, by G. WebBe Dasent, D.C.L. 4to, cloth. 1874. Price $€ 3,7 \mathrm{~s}$.

SKEAT.-LIST OF ENGLISH WORDS, the Etymology of which is Illus. trated by Comparison with Icelandic. By W. W. Skeat, M.A. Prepared as an Appendix to Cleasby's Icelandic Dictionary. 4to, paper. Price 2s.

VIGFUSSON AND POWELL.-ICELANDIC PROSE READER, with Notes, Grammar, and Glossary. By Dr. Gudbrand Vigfusson and F. YORK Poweld, M.A. Fcap. 8vo, cloth. 1879. Price 10s. 6d.

\section{ITALIAN.}

AHN.-NEW, PRACTICAL, AND EASY METHOD OF LEARNING THE Italian Language. By Dr. F. Ahr. First and Second Course. Tenth Issue. I 2 mo, cloth, pp. iv. and i98. I878. Price 3\%. 6 d.

CAMERINI.-L'ECo ITALIANo. A Practical Guide to Italian Conversa. tion. By Eugene Camerini. With a Complete Vocabulary. Second Edition. Crown 8vo, cloth, pp. viii., 128, and 98. 1871. Price 4s. 6Il.

LANARI. - COLLECTION OF ITALIAN AND ENGLISH DIALOGUES ON General SubJects. For the Use of those Desirous of Speaking the Italian Language Correctly. Preceded by a Brief Treatise on the Pronunciation of the same. By A. LANari. I 2 mo, cluth, pp. viii. and 199. Price 3s. 6s.

MILLHOUSE. - MANUAL OF ITALIAN CONVERSATION, for the Use of Schools and 'Travellers. By JoHn Milunouse. New Edition. I8mo, cloth, pp. 126. 1879. Price 2s. 
MILLHOUSE. - NEW ENGLISH AND ITALIAN PRONOUNCING AND Explanatory Dictionary. By John Millhouse. Vol. I. EnglishItalian. Vol. II. Italian-English. Sixth Edition. 2 vols. square 8 vo, cloth, pp. 654 and 740. I887. Price I 2s.

NOTLEY. - COMPARATIVE GRAMMAR OF THE FRENCH, ITALIAN, Spanish, and Portuguese Languages. With a Copious Vocabulary. By Edwin A. Nothey. Oblong 12mo, cloth, pp. xv. and 396. 1868. Price 7s. 6d.

TOSCANI.-ITALIAN CONVERSATIONAL COURSE. A New Method of Teaching the Italian Language, both Theoretically and Practically. By Giovanni Toscani, late Professor of the Italian Language and Literature in Queen's College, London, \&c. Fifth Edition. I2mo, cloth, pp. xiv. and 300. I880. Price 5s.

TOSCANI.-ITALIAN READING COURSE. Comprehending Specimens in Prose and Poetry of the nost distinguished Italian Writers, with Biographical Notices, Explanatory Notes, and Rules on Prosody. By G. Toscani. I $2 \mathrm{mo}$, cloth, pp. xii. and 160 . With Table of Verbs. I875. Price 4s. 6d.

\section{LATIN.}

*IHNE.-LATIN GRAMMAR FOR BEGINNERS, on Ahn's System. By W. H. IHNE, late Principal of Carlton Terrace School, Liverpool. Crown $8 v 0$, cloth, pp. vi. and I84. I864. Price 3s.

LEWIS.-JUVENALIS SATIRE. With a Literal English Prose Transla. tion and Notes. By J. D. Lewis, M. A., Trinity College, Cambridge. Second Edition. 2 vols. 8vo, cloth, pp. xii. and 230 and $400 . \quad 1882$. Price I2s.

LEWIS.-THE LETTERS OF PLINY THE YOUNGER. Translated by J. D. Lewis, M.A., Trinity College, Cambridge. Post 8 vo, cloth, pp. vii. and 390. I879. Price $5 \mathrm{~s}$.

LEWIS AND SHORT.-IATIN DICTIONARY. Founded on Andrews' Edition of Freund's Latin Dictionary. Revised, Enlarged, and in great part Re-written by Charlton T. Lewis, Ph.D., and Charles Short, LL.D. 4to, cloth. 1879. Price $£$ I, I Is. 6d.

NEWMAN.-HIAWATHA. Rendered into Latin. With Abridgment. By F. W. Newman. I2mo, sewed, pp. vii. and I Io. 1862. Price 2s. 6d. NEWMAN. - TRANSLATIONS OF ENGLISH POETRY INTO LATIN VERSE. Designed as Part of a New Method of Instructing in Latin. By F. W. Newman. Crown 8vo, cloth, pp. xiv. and 202. 1868. Price 6s.

\section{POLISH.}

BARANOWSKI.-SLOWNIK POLSKO-ANGIELSKI OPRACOWANY. PrzeZ J. J. Baranowskiego, 6 Podsekretarza Fanku Polskiego, w Warszawie. (Polish-English Lexicon. With Grammatical Rules in Polish.) I6mo, cloth, pp. 403. Price I2s.

BARANOWSKI.-ANGLO-POLISH LEXICON. By J. J. BARANOWSKI, formerly Under-Secretary to the Bank of Poland, in Warsaw. (With Grammatical Rules in English, and a Second Part, containing Dialogues, Bills of Exchange, Receipts, Letters, \&c. ; English and Polish Proverbs, \&c.) I6mo, cloth, pp. vii. 400 and 90. Price 12s. 
*MORFILL. -SIMPLIFIED GRAMMAR OF THE POLISH LANGUAGE. By W. R. Morfill, M.A. Crown 8vo, pp. viii.-64, cloth. I884. Price 3s. 6 d.

\section{PORTUGUESE.}

*ANDERSON AND TUGMAN. -MERCANTILE CORRESPONDENCE. Con. taining a Collection of Commercial Letters in Portuguese and English, with their Translation on opposite pages, for the Use of Business Men and of Students in either of the Languages, treating in Modern Style of the System of Business in the principal Commercial Cities of the World. Accompanied by pro forma Accounts, Sales, Invoices, Bills of Lading, Drafts, \&c. With an Introduction and Copious Notes. By WrLlram Anderson and James E. Tugman. I2mo, cloth, pp. xi. and 193. 1867. Price 6s.

*D'ORSEY.-PRACTICAL GRAMIMAR OF PORTUGUESE AND ENGLISH. Exhibiting in a Series of Exercises, in Double Translation, the Idiomatic Structure of both Languages, as now written and spoken. By the Rev. Alexander J. D. D'Orsey, B.D., of Corpus Christi College, Cambridge, and Lecturer on Public Reading and Speaking at King's College, London. Third Edition. Crown 8vo, cloth, pp. viii. and 302. I868. Price $7 \mathrm{~s}$.

*D'ORSEY.-COLLOQUIAL PORTUGUESE ; or, Words and Phrases of Every. day Life. Compiled from Dictation and Conversation. For the Use of English Tourists in Portugal, Brazil, Madeira, and the Azores. With a Brief Collection of Epistolary Phrases. By the Rev. A. J. D. D'Orsey. Fourth Edition, enlarged. Crown 8vo, cloth, pp. viii. and I26. 1886. Price 3s. 6d.

NOTLEY. - COMPARATIVE GRAMMAR OF THE FRENCH, ITALIAN, Spanish, and Por'iuguege Languages. With a Copious Vocabulary. By Edwin A. Nothey. Oblong r2mo, cloth, pp. xv. and 396. 1868. Price 7s. 6d.

\section{ROUMANIAN.}

*TORCEANU.-SIMPLIFIED GRAMMAR OF THE ROUMANIAN LANGUAGE. By R. Torceand. Crown 8vo, cloth, pp. viii. and 72. 1884. :Price 5s.

\section{RUSSIAN.}

FREETH.-A CONDENSED RUSSIAN GRAMMAR for the Use of StaffOfficers and Others. By F. Freeth, B.A., late Classical Scholar of Emmanuel College, Cambridge. Crown 8vo, pp. iv. -75 , cloth. 1886. Price 38. 6d.

* RIOLA. - HOW TO LEARN RUSSIAN. A Manual for Students of Russian, based upon the Ollendorffian System of Teaching Languages, and adapted for Self-Instruction. By HeNry RIola, Teacher of the Russian Language. With a Preface by W. R. S. Ralston, M.A. Second Edition. Crown 8vo, cloth, pp. x. and 567. 1883. Price r2s. KeY to Ditto. Crown 8vo, cloth, pp. 126. Price $5 \mathrm{~s}$.

*RIOLA.-GRADUATED RUSSIAN READER, with a Vocabulary of all the Russian Words contained in it. By Henrx Riola. Crown 8vo, cloth, pp. viii. and 314. I879. Price 1os. 6d. 
THOMPSON.-DIALOGUES, RUSSIAN AND ENGLISH. Compiled by A. R. Thompson, some time Lecturer of the English Language in the University of St. Vladimir, Kieff. Crown 8ro, cloth, pp. iv. and $\mathbf{I}^{32 .}$ 1882. Price 5s.

\section{SPANISH.}

*BUTLER. - THE SPANISH TEACHER AND/COLLOQUIAL PHRASE-BOOK. An Easy and Agreeable Method of acquiring a Speaking Knowledge of the Spanish Language. By Francis Butrer. I8mo, half-roan, pp. xvi. and 240. I870. Price 2s. $6 \mathrm{~d}$.

HARTZENBUSCH AND LEMMING.-ECO DE MADRID. A Practical Guide to Spanish Conversation. By J. E. Hartzenbusch and $\mathrm{H}$. Lemming. Third Edition. Crown 8vo, cloth, pp. xii., I44, and 84. I877. Price 5s.

*CARRENO. METODO PARA APRENDER A LEER, escribir y hablar el Inglés segun el sistema de Ollendorff, con un tratado de pronunciacion. al principio y un Apendice importante al fin, que sirve de comple. mento a la obra. Por Rayon Palenzuela y JUAN de la Carreño. Nueva Edicion, con una Pronunciacion Figurada segun un Sistema Fonografico, por Robert Goodacre. Crown 8vo, cloth, pp. iv. and 496. I876. Price 7s. 6d.

Kex to Ditto. Crown 8vo, cloth, pp. II . Price 4s.

NOTLEY.-COMPARATIVE GRAMMAR OF THE FRENCH, ITALIAN, Spanish, and Pontuguese Languages. With a Copious Vocabulary. By Edwin A. Nothey. Oblong I2mo, cloth, pp. xv. and 396. I868. Price 7s. 6d.

*SIMONNE.-METODO PARA APRENDER A LEER, escribir y hablar el Frances, segun el verdadero sistema de Ollendorff; ordenado en lecciones progresivas, consistiendo de ejercicios orales y escritos ; enriquecido de la pronunciacion figurada como se estila en la conversacion ; y de un Apéndice abrazando las reglas de la sintáxis, la formacion de los verbos regulares, y la conjugacion de los irregulares. Por TEodono Simonne, Professor de Lenguas. Crown 8vo, cloth, pp. $342 . \quad$ i876. Price 6s.

Key to Ditto. Crown 8vo, cloth, pp. 8o. Price 3s. 6d.

*VELASQUEZ AND SIMONNE. - NEW METHOD OF LEARNING TO READ, Write, aNd Speak the Spanish Language. Adapted to Ollendorff's System. By M. Velasquez and J. Simonné. Crown 8vo, cloth, pp. 558. 1880. Price 6s.

KeY to Ditto. Crown 8vo, cloth, pp. I74. Price 4s.

VELASQUEZ.-DICTIONARY OF THE SPANISH AND ENGLISH LAN. GUAGES. For the Use of Learners and Travellers. By M. Velasquez de la Cadena. In Two Parts.-I. Spanish-English ; II. EnglishSpanish. Crown 8vo, cloth, pp. viii. and 846. I878. Price 7s. 6d.

VELASQUEZ.-PRONOUNCING DICTIONARY OF THE SPANISH AND English Languages. Composed from the Dictionaries of the Spanish Academy, Terreros, and Salvá, and Webster, Worcester, and Walker. In Two Parts.-I. Spanish-English; II. English-Spanish. By M. Velasquez de la Cadena. Roy. 8vo, cloth, pp. xvi., 675, xv., and. 604. I880. Price EI, 4s. 
*VELASQUEZ.-NEW SPANISH READER. Passages from the most approved authors, in Prose and Verse. Arranged in progressive order, with Vocabulary. By M. Velasquez de la Cadena. Crown 8vo, cloth, pp. 352. I880. Price 6s.

*VELASQUEZ. - AN EASY INTRODUCTION TO SPANISH CONVERSATION, containing all that is necessary to make a rapid progress in it. Particularly designed for persons who have little time to study, or are their own instructors. By M. Velasquez de la Cadena. New Edition, revised and enlarged. I2mo, cloth, pp. viii. and I39. I863. Price 2s. 6d.

\section{SWEDISH.}

OMAN.-SVENSK-ENGELSK HAND-ORDBOK. (Swedish-English Dictionary.) By F. E. OMAN. Crown 8vo, cloth, pp. iv. and 470. I872. Price 8s.

*OTTÉ.-SIMPLIFIED GRAMMAR OF THE SWEDISH LANGUAGE. BУ E. C. Oтté. Crown 8vo, pp. xii.-70, cloth. 1884. Price 2s. 6d.

\section{TURKISH.}

ARNOLD.-SIMPLE TRANSLITERAL GRAMMAR OF THE TURKISH Language. Compiled from Various Sources. With Dialogues and Vocabulary. By Edwin Arnold, M.A., C.S.I., F.R.G.S. I8mo, cloth, pp. 8o. 1877. Price 2s. 6d.

HOPKINS.-ELEMENTARY GRAMMAR OF THE TURKISH IANGUAGE. With a few Easy Exercises. By F. L. Hopkins, M.A., Fellow and Tutor of Trinity Hall, Cambridge. Crown 8vo, cloth, pp. $48 . \quad$ I877. Price 3s. 6d.

REDHOUSE.-THE TURKISH VADE-MECUM OF OTTOMAN COLLOQUIAL LANGUAge: Containing a Concise Ottoman Grammar; a Carefully Selected Vocabulary, Ajphabetically Arranged, in Two Parts, English and Turkish, and Turkish and English; also a Few Familiar Dialogues and Naval and Military Terms. The whole in English Characters, the Pronunciation being fully indicated. By J. W. ReDHouse, M.R.A.S. Third Edition. Fourth Thousand. 32mo, cloth, pp. viii. and 368 . 1882. Price 6s.

*REDHOUSE.-A SIMPLIFIED GRAMIMAR OF THE OTTOMAN TURKISH Language. By J. W. Rephouse, M.R.A.s. Crown 8vo, cloth, pp. xii. and 204. 1884, Price Ios. 6d.

REDHOUSE.-A TURKISH AND ENGLISH LEXICON. Showing in Eng. lish the Signification of the Turkish Terms. By J. W. Re:phouse, M.R A.S. Parts I. to III. Imperial 8vo, paper covers, pp. 960. 1884-85. Price 27s.

LONDON : TRÜBNER \& Co., 57 \& 59 LUDGATE HILL.

PRINTED BY BALLANTYNE, HANSON AND CO.

$500-7 / 2 / 87-\mathrm{C}$ EDINRIJRGH AND LONDON. 


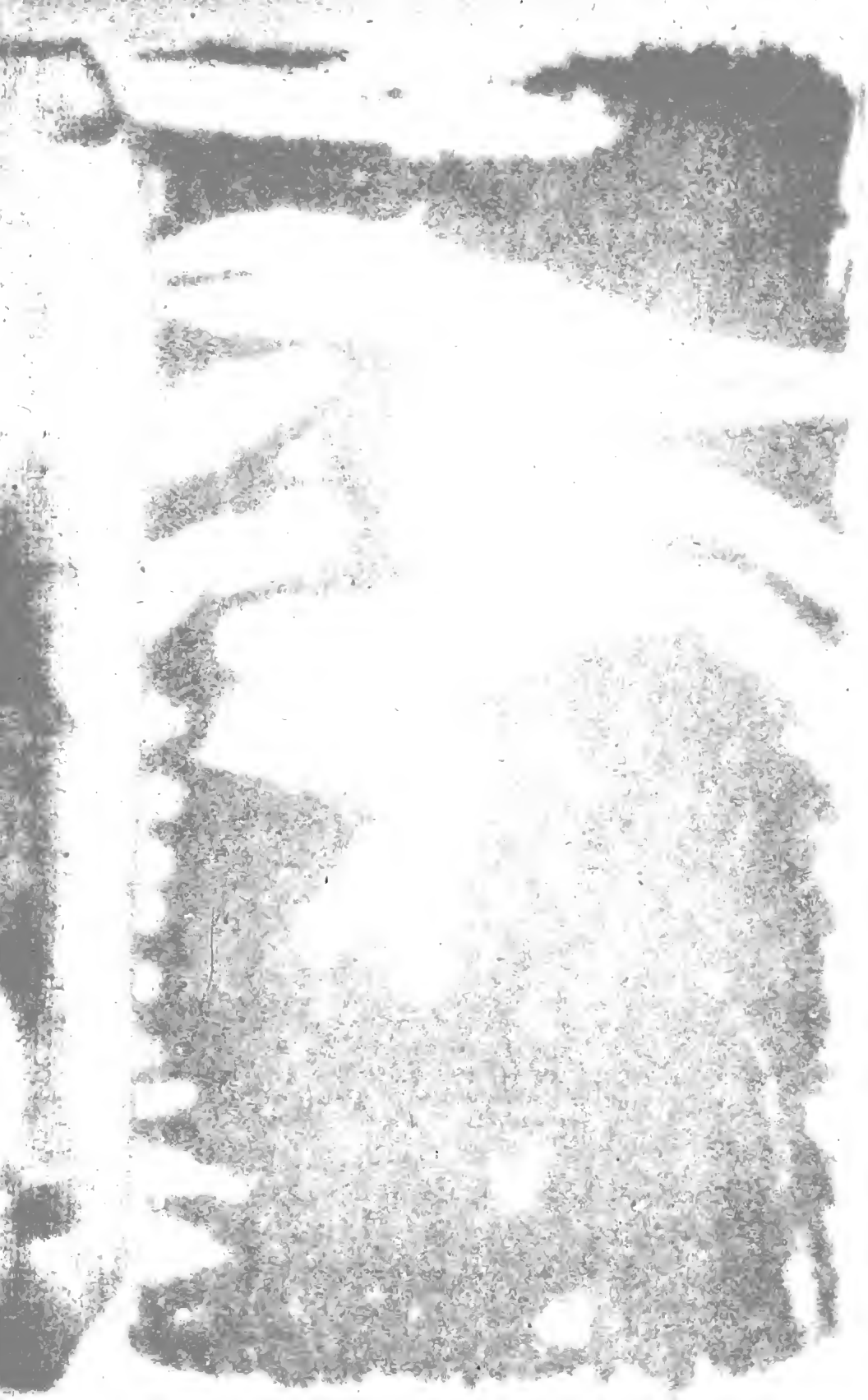


cllar-g4.1894 
YB 12427 
